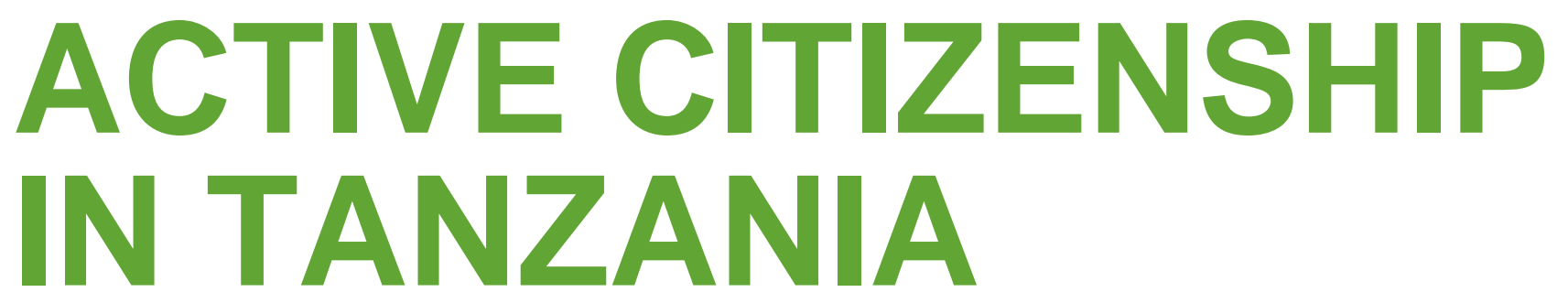

\title{
Impact Evaluation of the 'Governance and Accountability through Digitalization' project
}

\section{Impact Evaluation Report 2017-2019}

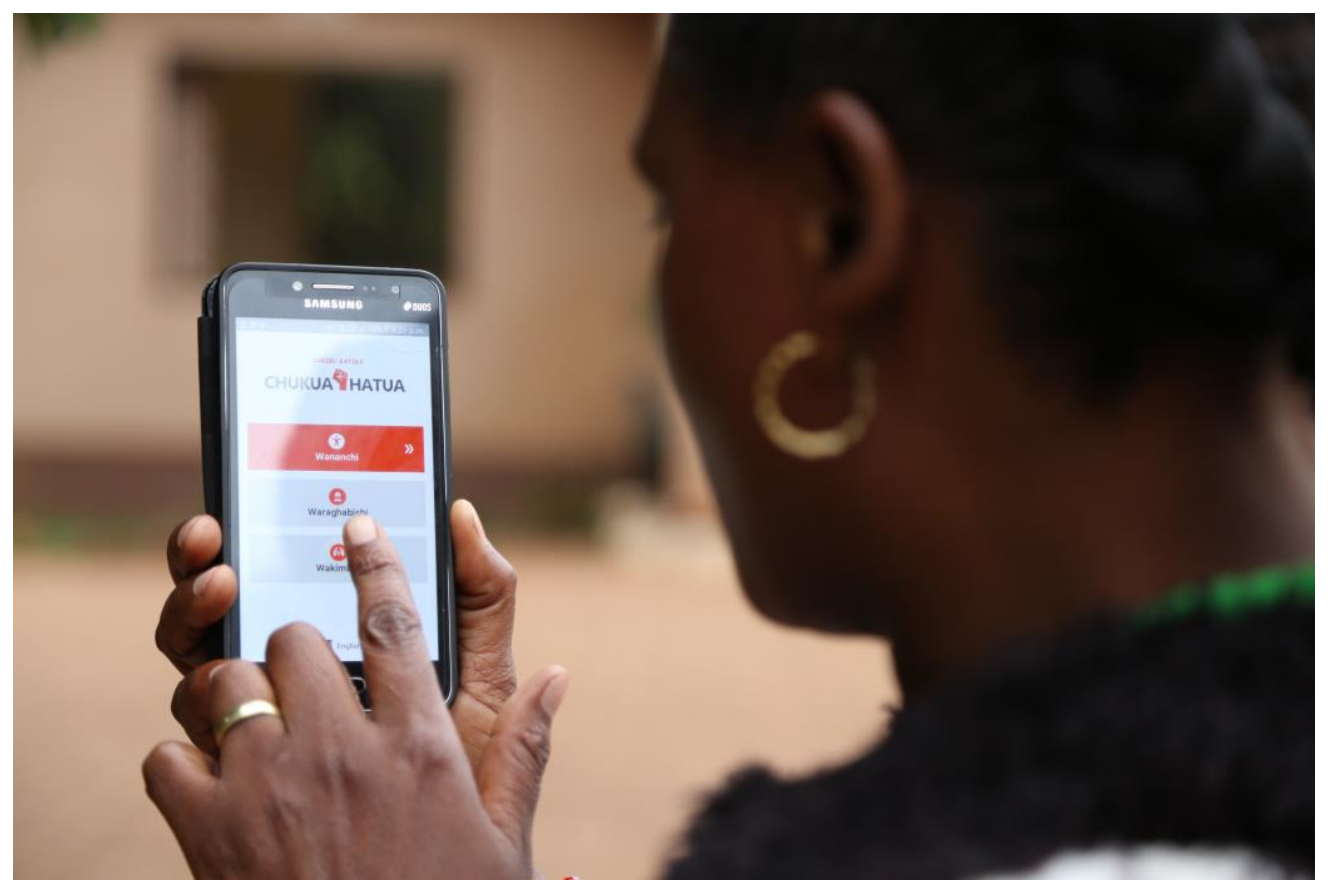

A community animator trying out the newly designed Chukua Hatua App for information access and sharing. Photo Credit: Bill Marwa/Oxfam.

\section{Alexia Pretari}

\section{OXFAM GB}

Esther Towo, Benson Ndiege, Ezra Wango, Mwanahawa Mhina: Qualitative case studies collection and analysis Nicole Schwitter and Ulf Liebe: Twitter data collection and analysis

Ravens Consulting: Conducting the quantitative data collections on behalf of Oxfam
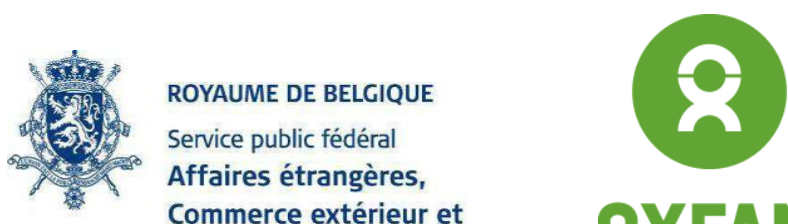


\section{ACKNOWLEDGEMENTS}

We would like to thank Oxfam in Tanzania, and particularly Neema Lontang'Amwaki, Stellah Julius, Agatha Bugomola, Bill Marwa, Jackline Mlay, Narsisi Silvesti, Amina Ndiko, Joseph Kajuli, Betty Malaki and Laurent Wambura, for their support in carrying out the different activities involved in this impact evaluation. Particular thanks are due to Oxfam's partners and all the participants in the launch workshop for the baseline held in September 2017.

We also thank Ravens Consulting, and in particular Augustine Malero, Abdallah Hussein, Boniphace Shimba, Jumanne Kisweka, Samwel Mungure and Abbas Ismail, for their leadership in the survey process, and all the research assistants for being committed to collecting data, both at baseline and endline.

We would also like to thank Marta Arranz, Rosa Garwood, Manu Savani, Amy O'Donnell, Jo Rowlands, Emily Tomkys Valteri, Jacky Repila, Andrea Azevedo and Jaynie Vonk for their various contributions at different points in the development of this work. Special thanks are due to Joelle Semaan for her overall support, literature review and major contributions to the baseline questionnaire, and to Simone Lombardini for his support throughout the design of this evaluation and for initiating the collaboration with the University of Warwick.

This report combined different sources of data and analyses. The Twitter data analysis was carried out by Nicole Schwitter and Ulf Liebe from the University of Warwick, UK. The qualitative case studies were carried out by Esther Towo, Benson Ndiege, Ezra Wango and Mwanahawa Mhina from Moshi Co-operative University, Tanzania. Many thanks to all of them for this collaboration.

Finally, thanks are due to all of the interviewees who gave their time and fed information back for this evaluation to be possible. 


\section{CONTENTS}

Contents

Executive Summary

2 Project description 10

3 Evaluation design $\quad 15$

4 Results $\quad 25$

5 Conclusions $\quad 67$

$\begin{array}{ll}\text { References } & 91\end{array}$

$\begin{array}{ll}\text { Notes } & 92\end{array}$ 


\section{EXECUTIVE SUMMARY}

Oxfam in Tanzania launched the 'Governance and Accountability through Digitalization' project in 2017, aimed at improving community-driven governance and accountability through the use of digital technology. The project built on the traditional animation approach developed through Oxfam's former project 'Chukua Hatua': community animators are village level organizers or facilitators who mobilize or 'animate' communities around a common advocacy agenda. The project enhanced it by integrating the use of digital tools into the animation approach. It is a collaboration between Oxfam in Tanzania, Oxfam-Solidarité (Belgium) and the Pastoral Livelihood Support and Empowerment Programme (PALISEP) in Arusha, Capacity Building Initiatives for Poverty Alleviation (CABUIPA) in Geita, and Mtwara Society Against Poverty (MSOAPO) in Mtwara. It took place in rural areas in Arusha, Mtwara, Kigoma and Geita in Tanzania, and in the Nduta refugee camp in Kigoma, which hosts refugees from Burundi.

The project was implemented between February 2017 and March 2019. During this time, several researchers and analysts have expressed increasing concerns about the shrinking of civic spaces in East Africa and a change in the political climate in Tanzania. Human Rights Watch World Report 2019 highlights that 'since the election of President John Magufuli in December 2015, Tanzania has witnessed a marked decline in respect for free expression, association, and assembly. Rhetorical Attacks on rights by authorities are increasingly accompanied by implementation of repressive laws and the harassment and arrest of journalists, opposition members and critics.' In particular, the Cybercrime Act of 2015 has resulted in cases of criminalization of the sharing of information on online platforms. The report also highlights that rights of children, women, lesbian, gay, bisexual and transgender (LGBT) people and Burundian refugees have been threatened.

An impact evaluation has been embedded into the project design to assess the value added of digital technologies to promote human rights, compared to traditional approaches to animation. The project and its impact evaluation were funded by the Belgian DirectorateGeneral for Development Cooperation and Humanitarian Aid.

\section{EVALUATION APPROACH}

The impact evaluation analyses the added-value of the digitalization component, compared to a traditional animation approach, between September 2017 and February 2019. The quantitative quasi-experimental design explored the impact at scale among citizens, and to a lesser extent, among animators. It is complemented by four qualitative case studies, which explore how relationships between the key actors have evolved with the introduction of the digitalization component, among four successful cases of mobilization which led to observed changes. The data generated on Twitter by animators and other stakeholders was also collected and helped to build a broader picture of the project. The three components together contribute to understanding the mechanisms that enabled the changes observed at scale. At baseline, a comparison group of villages in which animators were active, but not part of the current project, were identified to enable the assessment of the added-value of the digitalization component. The comparison group was formed from villages in which Chukua Hatua or another governance project relying on traditional animation approaches (Lindi rural) was implemented. In addition, only villages in which a $2 \mathrm{G}$ or $3 \mathrm{G}$ connection was available were included, and where animators were still active, could read and write, were not political or government leaders, and still resident in the village. Within sampled villages, animators were randomly sampled from the list of animators provided by partners and Oxfam. Among the project villages, random sampling of villages, stratified by region, was carried out, as was random sampling of animators when there was a large number of animators in the village. At citizen level, a random sample of households was drawn in each village; within households, the gender of the respondent was randomly determined to create a representative and 
balanced sample of women and men citizens. Animators and citizens were surveyed at baseline in September and October 2017, and at endline in February 2019, to form a panel.

The quantitative impact analysis is carried out using difference-in-differences, propensity score matching or multivariate regressions depending on the outcomes and sample considered. At citizen level. the average impact on citizens is estimated, as well as differential impacts for men and women citizens. This is because we expect men and women to engage in different ways with civic activities (animator-supported ones or regular ones) due to different constraints (domestic and work time commitment, access to information, and social norms around women's public participation in particular). Focus group discussions and key informant interviews were carried out in April 2019 among four successful cases of mobilization which led to observed changes. Each case was described in detail and emerging themes were analysed across the cases. Data was gathered from the Twitter platform in December 2018 and May 2019, and analysed using descriptive statistics and multivariate regressions. While each component separately explores different questions, bringing the three components together contributes to understanding the mechanisms that enabled the changes observed at scale.

\section{RESULTS}

As a result of the project, and compared to animators relying on traditional approaches to animation, we observed a change in online practices among the project animators: higher usage of social media overall and for animation-related activities. Significantly more animators use WhatsApp and Facebook groups on local issues as a result of the project, and use social media to be part of conversations with leaders. This is confirmed by the Twitter data analysis, which shows an increasing trend of tweets among animators after the project started, and following key activities of the project, while also showing regional variation on the matter. Different online platforms were indeed used for different purposes, depending on the regional context: which leaders or officials use a given platform on the one hand, and the perceived sensitivity to call-out leaders publicly in a setting of shrinking civic spaces on the other. The project had a significant impact on animators' connection with other animators within the village and outside. As a result of the project, animators also appeared to be more engaged with citizens than in the comparison group as a result of the project (meeting-up with citizens for individual conversations, organized meetings with citizens without officials, and with citizens and officials), but as likely to participate in village meetings. At time of the endline survey, project animators were significantly more likely to be willing to keep carrying out animation activities moving forward than animators in the comparison areas.

Among a representative sample of citizens, we observed that women and men citizens in the project villages are more likely to know the village animators as a result of the project, compared to women and men citizens in villages where animators rely only on a traditional animation approach. However, their offline engagement with animators or with civic activities (through discussion or meetings with animators, meetings among citizens, meetings with leaders or reporting of issues to officials) is not significantly impacted by the project. In villages where high level of mobilization and visible changes in human rights promotion were observed, transparency of leaders and increased awareness of citizens led to behavioural changes and increased participation in formal village meetings, according to the case studies. Sustained and stronger behavioural change of leaders and citizens will hence be key to see an impact at scale on participation in village meetings, opening-up formal spaces to bring about change. However, at scale,the project does have an impact on the topics of the issues discussed in community dialogues, as well as the one reported directly to the authorities. As a result of the project, women citizens in particular are more likely to report issues related to violence to the leaders, while men are more likely to report issues related to access to water. Note that these mechanisms led to different topics being discussed overall, and by women and men citizens in particular, as community dialogues are open and public spaces, while reporting is a private mechanism. 
Citizens' access to and use of online platforms is very low - even lower for women compared to men - and not impacted by the project. The main limitation identified by citizens is the lack of access to devices. The qualitative case studies highlight that there is interest, particularly among youth. Through the quantitative data, age is indeed identified as a key characteristic of citizens using social media.

The project contributed to building citizens' sense of 'power to', in particular through the development of individuals' ability to decide for themselves about their participation in community activities, or travelling outside of the community, and their attitude to public forums. We do not measure an impact on citizens' sense of 'power within', nor on active citizenship, as defined in the setting of the project.

As a result of the project, and compared to villages in which traditional animation is ongoing at baseline, leaders and officials at different levels (village, ward, district) were more likely to open spaces to animators 18 months after the project started. The qualitative case studies show that the relationship between animators and leaders has not been an easy one from the start. There have been conflicts between animators and leaders or officials, and a lot of efforts made to build relationships, including through mitigation by the project's team. This seems to be particularly strong in areas in which supported animation practices did not exist before the project under review.

There is evidence that some aspects of governance at village level have improved (village meetings more frequent), but citizens also report that leaders are less likely to address the individual issues they report. At ward or district level, leaders are perceived as more available and transparent by citizens.

As a result of the project, animators are more likely to share stories of mobilization, to share stories in which social media was involved and to assess that the mobilization had a more positive outcome, than animators in the comparison group. On the other hand, citizens in the project villages are as likely as citizens in the comparison group to share such a story, and the content of the story is not different (their own involvement, involvement of social media, outcome of the mobilization). It is important to highlight that overall, citizens are less likely to be involved than animators in the story they shared. The qualitative case studies present in detail four cases of mobilization, which involved the use of smartphones and social media, and which led to actual changes in the village. These are related to school facilities, school staff and land use by a company in two villages in Arusha and one village in Kigoma. In the refugee camp, the qualitative case study describes mobilization supported by the use of smartphones related to water and sanitation infrastructure maintenance, domestic physical violence and sexual violence against women. As this theme emerged from the case studies, we reclassified the stories shared by the animators and found that animators in the project areas are significantly more likely to share stories of mobilization about discrimination or violence against women than ones in the comparison areas.

At scale, there is evidence that the project has resulted in some change in social services with more areas of social services in which renovation, improvement or building have been undertaken than in the comparison group (although the total number of renovations or improvements is not statistically significantly different between the two groups), and more plans seem to have been initiated for future building or improvement. More households have received compensation from a company using their land (small effect size, but significant at 5 percent). The project did not affect awareness of citizens or prevalence of cases of landrights violation. However, the project resulted in significantly more awareness of unequal inheritance practices for women, and of marriage of girls under 18 among men and women citizens.

When looking at the assumptions behind the introduction of the ICT component, and what this component was aimed to enable, the data gathered by the different sources help 
invalidate some assumptions and identify the strongest ones. First, as mentioned above, a very small share of citizens engage with online platforms - and an even smaller share of women - making the online platforms a tool mainly for interaction between animators and leaders, although the case studies show that there is interest, in particular among the youngest citizens. The ICT component enables animators to access new spaces, which are perceived to have less direct control (WhatsApp groups in particular), and to coordinate among themselves, as well as to improve their connectedness and strengthen the network of animators. Animators can search information thanks to the smartphones and the internet, and subsequently share it among themselves. Access to Twitter and WhatsApp in particular has enabled animators to access new spaces to call-out leaders. Both platforms are used for different purposes, however, depending on who has to be reached, who will listen and the context specific to each region. The qualitative case studies indeed show that ward or village leaders do not necessarily have access to the technology themselves, which could be a source of tension. In addition, depending on the region, district or regional leaders or officials may be part of WhatsApp groups with animators and citizens, but may not be on Twitter. Overall, Twitter has been used to reach national level leaders or stakeholders. The analysis of the data gathered from animators and influencers of the project also shows that engagement was built over time and that the use of the \#chukuahatua was critical for tweets to get traction.

While the impact evaluation is looking at the impact after 18 months of activities, which is a very short timeframe, a key question is about the sustainability of the approach. The evidence gathered shows that in February 2019, animators were willing to keep carrying on animation activities (more so than in the comparison group), and they are still tweeting at the time of writing of the report (two months after the end of the direct project's support). Both the Twitter data analysis and the qualitative case studies highlight that a few animators had become as active as the social media influencers by the end of the project. However, drawing from the comparison group trend of changes in behaviour over time, there may be a risk of disengagement. Drawing from baseline targeting process and quantitative survey experience and the qualitative case studies, there also seems to be a trend for animators to become involved in politics after their being involved in such a project.

At citizen level, the sustainability of the project will also depend on leaders' responsiveness over time at different government levels. If renovation plans are not implemented or individual issues reported more rarely addressed, there will be a risk of disappointment and further disengagement.

\section{PROGRAMME LEARNING CONSIDERATIONS}

\section{Identify the current barriers for citizens, and women citizens in particular, to engage with animators and civic activities}

Citizens who are the most likely to know the animators are more likely to be men than women, more likely to already be involved in the decision making of community groups than not, and to be in Mtwara and Kigoma, compared to the other regions. Moving forward, understanding the specific barriers that citizens of Arusha and Geita face in engaging with animators on the one hand, and the barriers for men who are not already involved in the decision making of community groups overall on the other hand, will be critical. Similarly, what are the factors that explain the fact that women are significantly less likely to know the animators on the one hand, and to engage with online platforms and offline civic activities on the other hand? Understanding specific barriers that women face and reasons they put forward for not engaging online or offline will be critical to defining appropriate strategies. In addition, not all women will face the same barriers (the situation in Arusha and Geita may be different from Mtwara and Kigoma, as mentioned above for example, but also within each 
village). This will require consulting women and men citizens, and particularly the ones that are not already close to Oxfam, partners, animators or village institutions.

\section{Consider supporting citizens' organizing among themselves}

In the project areas in September 201715 percent of citizens participated in meetings among themselves and 16 percent participated in meeting with animators without officials. This has not been significantly impacted by the project. This is an overall low share of citizens while Chukua Hatua's first pilot identified 'the lack of spaces and forums for citizens to discuss their accountability issues among themselves' as a struggle to be tackled (Oxfam's Rights to be heard framework, Hopkins et al., 2014). In the absence of widely owned informal closed spaces for citizens, and given that online spaces, such as WhatsApp groups, are not available to most citizens but are to animators, there is a risk of the animation approach becoming very centralized and somehow disconnected from the citizens. Moving forward, it will be key to identify how to strengthen the link between animators and citizens, and make sure that animators open up safe spaces - which they are part of or not - for women and men citizens to organize and contribute to setting up their reform agenda.

\section{Strengthen the project's strategies to support relationship-building between animators and leaders, at village level in particular, and to mitigate risks for animators}

While animators are accessing technology through the project, village- and ward-level leaders (and sometimes higher level as well) do not have access to such technology, and this was sometimes perceived as threatening. The project worked with leaders at the inception phase and has developed strategies throughout the project to mitigate risks for animators, to diffuse tensions between leaders and animators and to strengthen their collaboration. This component has been key and will have to be strengthened, particularly in areas where Chukua Hatua was not pre-existing. Similarly, during the project lifespan, civic spaces in Tanzania have shrunk, and control over online spaces has been strong, according to analysts and researchers. Risk mitigation, offline and online, is a critical component to carry forward. 
In a context of commitments to improve democratic governance in Tanzania, and of increasing mobile network subscribers and internet penetration, Oxfam in Tanzania launched a new project in 2017, aimed at improving community-driven governance and accountability through the use of digital technology. This project is the result of collaboration between Oxfam in Tanzania, Oxfam-Solidarité (Belgium) and Pastoral Livelihood Support and Empowerment Programme (PALISEP) in Arusha, Capacity Building Initiatives for Poverty Alleviation (CABUIPA) in Geita, Mtwara Society Against Poverty (MSOAPO) in Mtwara. It was implemented in Arusha, Geita, Mtwara and Kigoma, including in the Nduta refugee camp.

The project was implemented between February 2017 and March 2019. In these years, several researchers and analysts have expressed increasing concerns about the shrinking of civic spaces in East Africa and a change in political climate in Tanzania. According to Human Rights Watch Africa director Mausi Segun, 'We are seeing an alarming backsliding on human rights in East Africa and in the Horn as governments use violence and repression to silence peaceful dissent, while failing to ensure accountability for abuses by their forces'. ${ }^{1}$ Human Rights Watch World Report 2019 highlights that 'since the election of President John Magufuli in December 2015, Tanzania has witnessed a marked decline in respect for free expression, association, and assembly. Rhetorical Attacks on rights by authorities are increasingly accompanied by implementation of repressive laws and the harassment and arrest of journalists, opposition members and critics. In particular, the Cybercrime Act of 2015 has resulted in cases of criminalization of the sharing of information on online platforms. The report also highlights that rights of children; women; lesbian, gay, bisexual and transgender (LGBT) people and Burundian refugees have been threatened.

In this setting, the project under review built on traditional village-level animation approaches and enhanced it through the use of digital media. An impact evaluation has been embedded into the project design to assess the value added of digital technologies to promote human rights, compared to traditional approaches to animation. The project and its impact evaluation were funded by the Belgian Directorate-General for Development Cooperation and Humanitarian Aid.

This report presents the main results of the impact evaluation. An overview of the project is given first (Section 2), then the impact evaluation design is presented (Section 3). Section 4 describes the main results and Section 5 concludes and draws recommendations. 


\section{PROJECT DESCRIPTION}

\subsection{THE SETTING}

Oxfam in Tanzania in collaboration with Oxfam-Solidarité (Belgium) have received funding for the 'Governance and Accountability through Digitalization' project. This project seeks to address the current deficit in community driven governance reform, and to link these efforts to policy change and strengthened accountability at national level. To achieve this, Oxfam has taken its flagship governance programme Chukua Hatua ('Take Action') ${ }^{2}$ to a new level through innovative use of digital technology. Oxfam believes that digital (information and communications) technology is an enabler of solutions to development and human rights challenges, if implemented in the right manner.

To be effective, digital technology needs to complement and strengthen existing and proven approaches to enable more impactful, scalable and efficient interventions. Accordingly, Oxfam has been integrating digital technology into a proven existing governance model: that of community animators, village level organizers or facilitators who mobilize or 'animate' communities around a common advocacy agenda. Animators involved in the project were indeed already involved in community animation activities, through Oxfam support or not, and were provided with refresher training on animation techniques, among other trainings and forms of support (see Section 2.2).

The project targets 200 animators in four districts of Kibondo (Kigoma region), Mbogwe (Geita region), Ngorongoro (Arusha region) and Mtwara rural (Mtwara region), and citizens from 62 villages (i.e. women, men, and youth). The project is the result of the collaboration between Oxfam in Tanzania and four partner organizations: Pastoral Livelihood Support and Empowerment Programme (PALISEP) in Arusha, Capacity Building Initiatives for Poverty Alleviation (CABUIPA) in Geita, Mtwara Society Against Poverty (MSOAPO) in Mtwara. The project was funded by the Belgian Directorate-General for Development Cooperation and Humanitarian Aid.

The project took place within the setting of Tanzania's Cybercrime Act of 2015, which criminalized and penalized different cyber activities. This act has been criticized from the very beginning by civil society as a threat to freedom of expression and as a means to control online spaces. ${ }^{3}$ The project was implemented between February 2017 and March 2019, and these years have seen a shrinking of the civic spaces in East Africa, and a change in political climate in Tanzania. According to Human Rights Watch Africa director Mausi Segun, 'We are seeing an alarming backsliding on human rights in East Africa and in the Horn as governments use violence and repression to silence peaceful dissent, while failing to ensure accountability for abuses by their forces. ${ }^{4}$ Human Rights Watch World Report 2019 highlights that 'since the election of President John Magufuli in December 2015, Tanzania has witnessed a marked decline in respect for free expression, association, and assembly. Rhetorical Attacks on rights by authorities are increasingly accompanied by implementation of repressive laws and the harassment and arrest of journalists, opposition members and critics.' In particular, the report highlights cases of criminalization of the sharing of information on WhatsApp, Facebook or other online platforms by citizens and activists following the Cybercrime Act of 2015. The report also highlights that the rights of children, women, LGBT people and Burundian refugees have been threatened. 


\subsection{PROJECT LOGIC AND EXPECTED OUTCOMES}

By leveraging digital tools, Oxfam intends to create a step change in the impact and scalability of its governance and accountability programming. Governance and accountability can be thought of at different scales, and this project mobilized different actors, online and offline. Figure 2.1 presents the project logic, highlighting these points.

Figure 2.1: Human Rights and Digitalization project logic, showing different scales

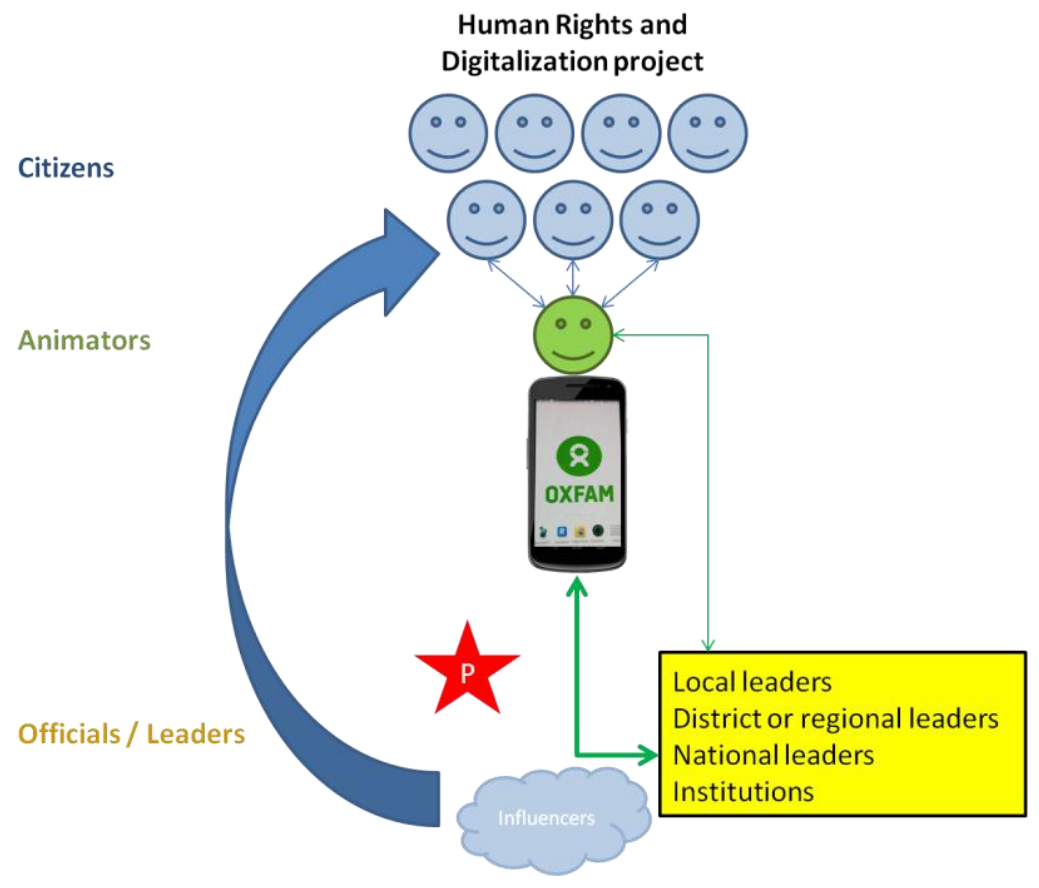

The primary mechanism for achievement of the project aims relies on placing the power and information of the internet in the hands of 200 community animators, through the provision of smartphones and training on the use of smartphones and available associated technology (internet search engine, WhatsApp, Facebook, Twitter and other social media, email, etc.) (broad green two-way arrow on the diagram). This mechanism comes in addition to offline interactions between animators and officials (thin green two-way arrow on the diagram). Animators indeed received introductory training on animation techniques (August to October 2017), training on the use of digital tools (October and November 2017) and refresher training on both animation and digital tools (July and August 2018).

To create an environment in which such community-driven activism is possible, Oxfam and partners (civil society organizations based in each district - red star on the diagram) play a key role in supporting the animators and facilitating relationships between animators and leaders or officials (at village, ward, district and regional levels) and managing risks. Oxfam's partners have been working closely with local leaders both during the inception phase and throughout the project. Sensitization workshops between leaders, partners and animators were carried out in each region between April and October 2018.

Finally, the project also seeks to strengthen the link between local activism enhanced by digitalization through animators, and national influencing, through the mobilization of influential bloggers and social media users, and a digitalization strategy (cloud on the diagram). In September 2017, a workshop was held with key influencers.

The Animator Summit, organized in February 2019 also contributed to sensitizing animators further on the use of social media, supporting and facilitating relationships between animators and leaders (at all levels, including national level) and mobilizing online influencers.

Governance and Accountability through Digitalization in Tanzania Impact Evaluation 2017-2019 
These mechanisms intend to provide citizens with the tools to bring their demand for human rights to duty bearers (officials at different levels and national institutions/service providers), which ultimately are expected to respond and act on such demand (broad blue arrow on the diagram). Also, animators are a bridge between citizens and leaders on the one hand and are a step towards making all citizens active (everyone becoming an animator). Following Rowlands 1997 and VeneKlasen and Miller 2002, the Powercube website ${ }^{5}$ defines four expressions of power:

- The most commonly recognized form of power, 'power over', has many negative associations for people, such as repression, force, coercion, discrimination, corruption, and abuse. Power is seen as a win-lose kind of relationship.

- 'Power within' has to do with a person's sense of self-worth and self-knowledge; it includes an ability to recognize individual differences while respecting others. 'Power within' is the capacity to imagine and have hope; it affirms the common human search for dignity and fulfilment.

- 'Power to' refers to the unique potential of every person to shape his or her life and world. When based on mutual support, it opens up the possibilities of joint action, or 'power with'.

- 'Power with' has to do with finding common ground among different interests and building collective strength.

These last three expressions of power contribute to understanding power as 'a positive force for individual and collective capacity to act for change'. These expressions of power are critical to Oxfam's Rights to be Heard framework (Hopkins et al., 2014), and to the project logic: animators mobilize, facilitate and provide an environment in which citizens build their 'power within', 'power to' and 'power with'.

To design the baseline and impact evaluation, a workshop was held with Oxfam in Tanzania and partners on 22 September 2017. During the workshop, the team worked on redefining active citizenship and responsive leaders in the setting of the project, and how the project will contribute to bringing about change. In this process, assumptions around the added-value of ICT as an enabler were pinned down and are presented in the figures below. These assumptions were revisited on 28 and 29 January 2019 to identify any points missed at the time of baseline. Discussions highlighted the role of social media influencers as online amplifiers of animators' voices and citizens' struggles (assumption 8). In addition, assumption 7 was reformulated to better reflect the network nature of animation and the expectation that the ICT component will strengthen it. The assumptions are as follows:

1 - Inviting/informing citizens in a more efficient manner (quicker, increase the reach)

2 - Creating new spaces for discussions with less direct control: WhatsApp groups and social media platform

3 - Searching for information: Google, social media

4 - Receiving information: information provided by other animators or active citizens (WhatsApp group, social media)

5 - Receiving information (top-down): information provided by Oxfam and partners through the project app

6 - Accessing new spaces to call out leaders online in the presence of outsider witnesses (WhatsApp group, social media): creation of spaces that leaders are part of, collaboration with other animators, ongoing online debates polls and discussions

7 - Coordination between animators is more efficient (quicker) and animators are more connected

8 - Amplifying role of other active social media users (bloggers and influencers). 
Figure 2.2: Active citizenship definition and relationship with project activities

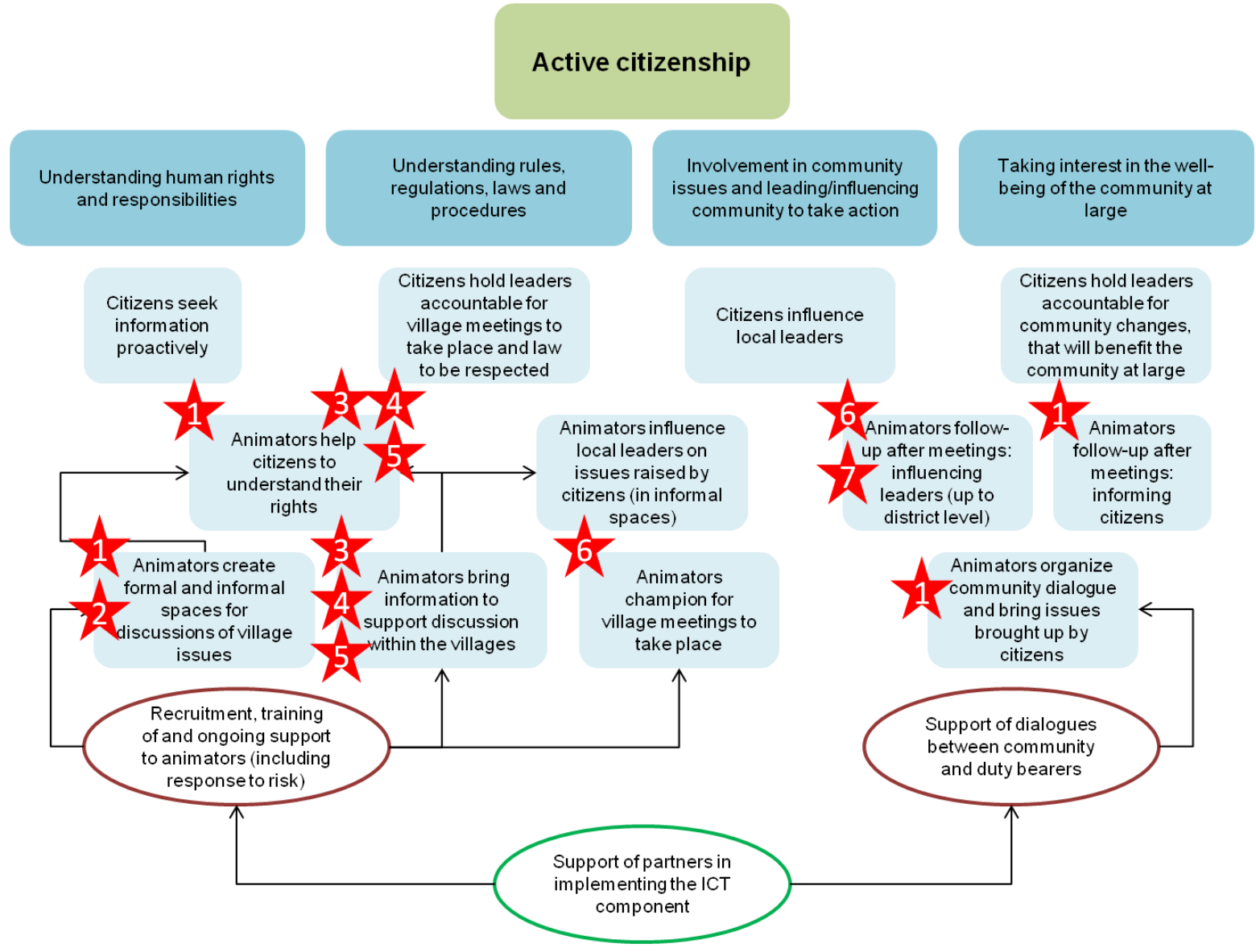

Figure 2.3: Responsive leaders definition and relationship with project activities

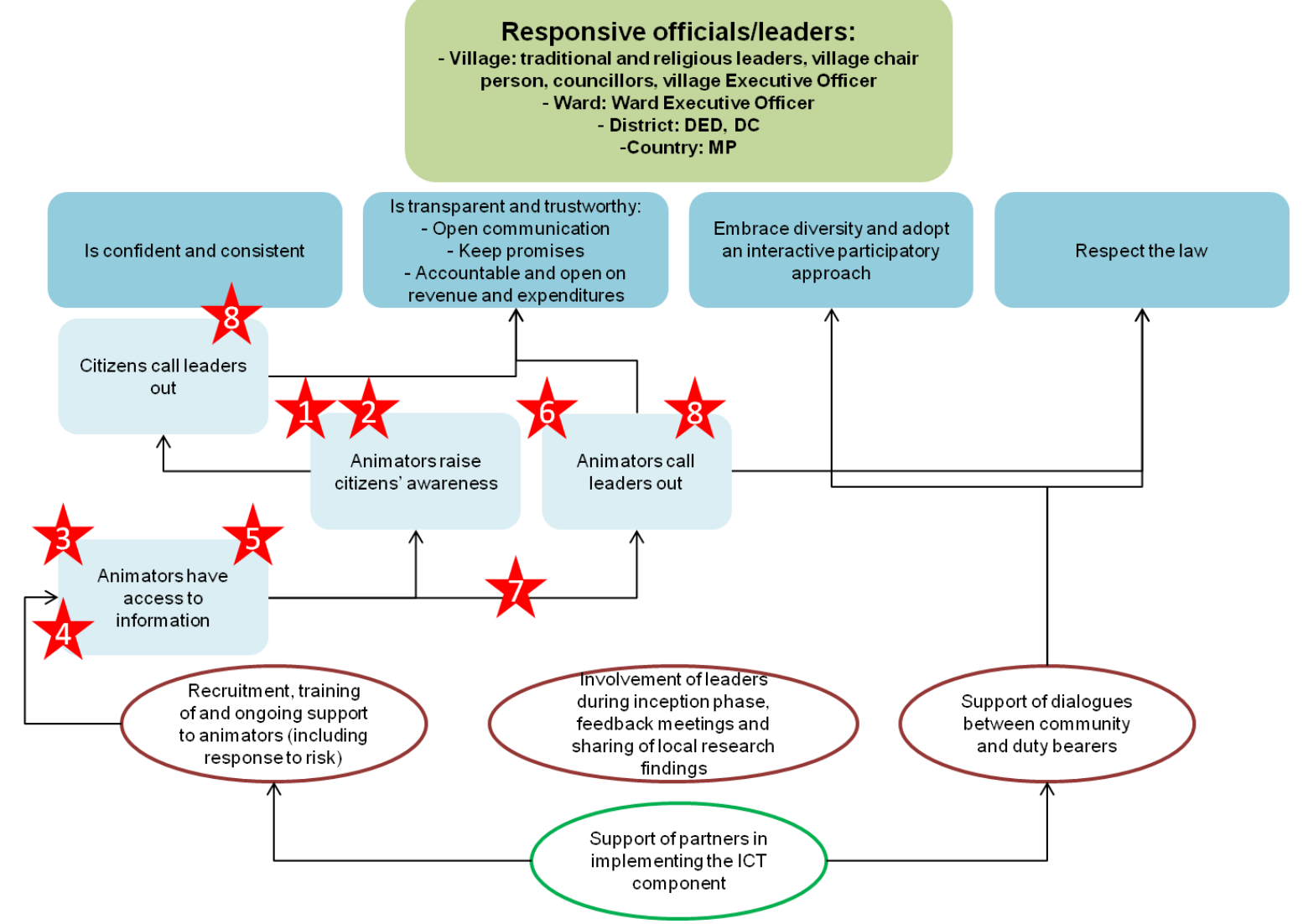

Governance and Accountability through Digitalization in Tanzania Impact Evaluation 2017-2019 


\subsection{SELECTION OF PROJECT SITES AND ANIMATORS}

As mentioned earlier, the project under review built on a previous project of community animation, namely Chukua Hatua, which took place in all the project regions but Kigoma, for different durations and in different modalities. The selection process of animators was implemented by partners and supported by Oxfam. The criteria identified initially were as follows:

- Villages where there was at least a $2 \mathrm{G}$ connection, and ideally $3 \mathrm{G}$

- In the three regions where Chukua Hatua was implemented, the focus was on villages involved in Chukua Hatua

- In the three regions where $\mathrm{CH}$ was implemented, the focus was on animators involved in Chukua Hatua previously.

Thus, 62 villages were identified in addition to the Nduta camp.

Animators were selected using the following criteria:

- Has taken part in animation activities (for Oxfam or other organizations)

- Can read and write (this criterion may not be met in very rare cases, if the animator is very active and well identified/influential in the community)

- Is not a political party leader, or involved in politics, nor a leader of the village/ward government ${ }^{6}$

- Is a resident of the village/locality

- Is confident, can explain issues clearly, is concerned about issues and bringing about change in their locality.

Overall, the project strategy relied on working with both women and men animators. This was to take into account gender dynamics and the fact that women citizens may feel more comfortable talking to other women, particularly on issues related to violence or discrimination, and ultimately ensure representation of women and men citizens' voices.

A total of 50 animators per region were involved in the project. Partners settled on different strategies to determine the number of animators per village, and the number of villages involved. In particular, in Mtwara and Kigoma (host communities), the number of animators per village was maximized: 10 villages are part of the project in Mtwara and five in the host communities in Kigoma, each with five animators. In Arusha, 25 villages are part of the project, with between one and four animators per village; in Geita, 21 villages are part of the project, with between one and six animators per village. 


\subsection{EVALUATION SCOPE AND QUESTIONS}

The impact evaluation was designed at baseline to assess whether and how the use of digital technology, as a component of a wider programme undertaken by Oxfam and partners, enables the promotion of human rights in a community-driven approach, compared to unsupported traditional animation methods.

The impact evaluation focuses on changes in the way technology enables animators and citizens to raise human rights issues in the thematic areas that are covered and in the level of engagement with local government. Because of the short duration of the project, the impact evaluation will not assess whether this engagement resulted in (or contributed to) changes in regional or national policies and practices.

The main design for the impact evaluation focuses on a quasi-experimental impact evaluation design with data collected at citizen and animator levels (blue outline in Figure 3.1) (see Section 3.2).

The analysis will assess to what extent the approach differs between ICT-enabled animation and traditional animation by looking at:

- How the use of ICT has affected the number and the demographic profile of citizens who engage with animators to discuss and raise human rights issues.

- How the use of ICT has affected the thematic areas and actions undertaken by the citizens.

- How the use of and access to ICT has affected the interaction of local governments with citizens in the project area.

The analysis will systematically look at the average impact and the differential impacts for men and women citizens. This is because we expect men and women to engage in different ways with civic activities (animator-supported ones or regular ones) because of different constraints (domestic and work-time commitment, access to information, social norms around women's public participation).

The analysis will also explore which mechanisms have enabled (or not) the promotion of human rights and access to social services through four case studies of villages and animators in which best practices were observed during project implementation (green outline in Figure 3.1) (see Section 3.3). In particular, the case studies will focus on how interactions between animators and leaders on the one hand, and interactions between animators and citizens on the other hand, were affected by the introduction of the ICT component, in a setting where high level of mobilization and visible changes in human rights promotion were observed. 
Figure 3.1: Impact evaluation design

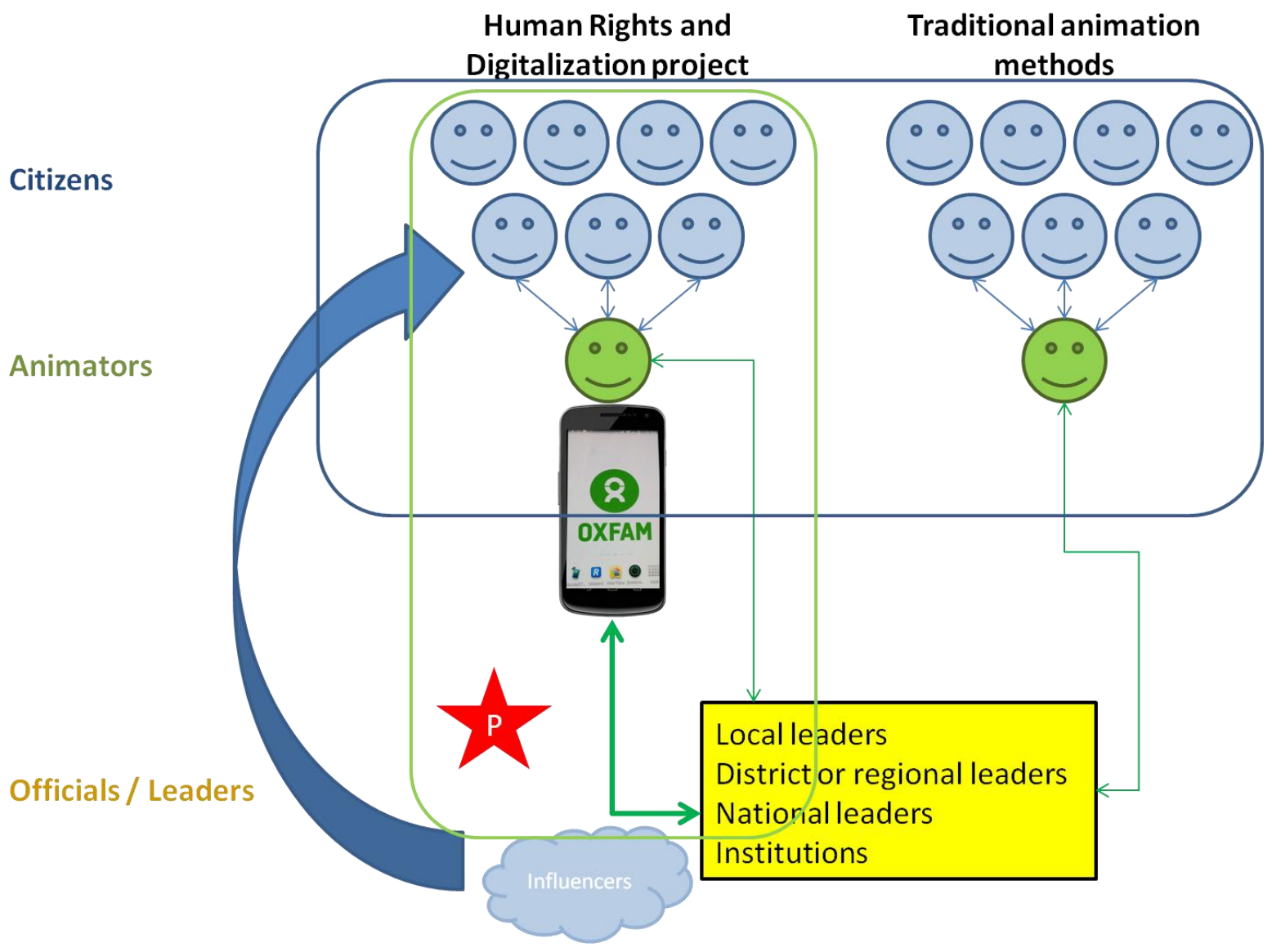

In addition, given the innovative nature of the online component of the project under review, and given that data are generated organically on online platforms, analysing these data would contribute to better understanding and describing the online activities. On the Twitter platform, public profiles and their associated activities can be viewed and the information collected, which is not the case for the other platforms mainly used in this project (WhatsApp and Facebook). The data generated on Twitter was hence collected for all influencers and animators involved in the project to capture and describe how animators and influences actually behaved, mobilized and interacted on this platform (red outline on Figure 3.2) (see Section 3.4). 
Figure 3.2: Twitter data analysis

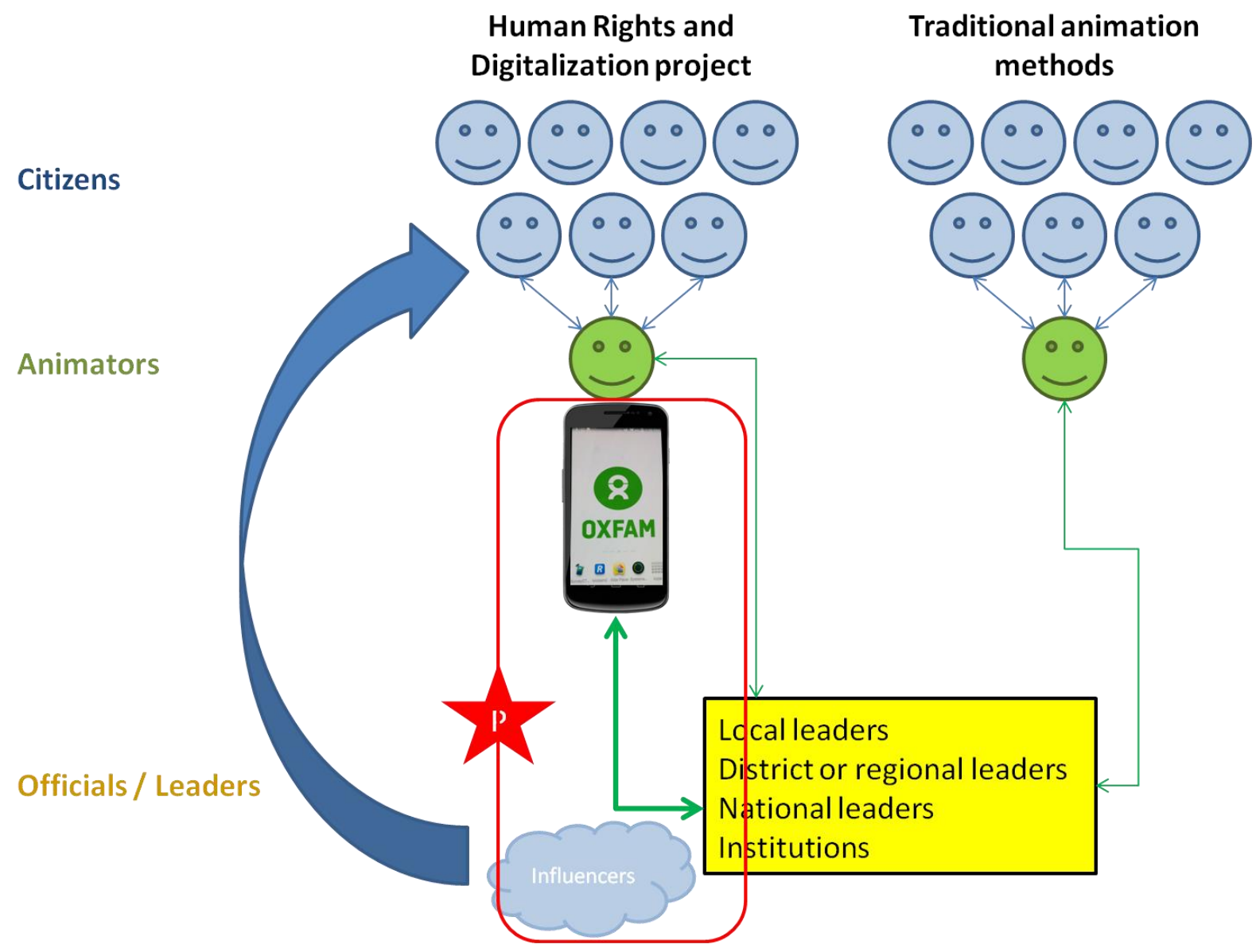

\subsection{QUASI-EXPERIMENTAL APPROACH}

The central problem in evaluating the impact of any project or programme is how to compare the outcomes that result from that project with what would have been the case without that project having been carried out. In the evaluation of programmes that involve a large number of units (whether individuals, households or communities), it is possible to make a comparison between units that were subject to the programme and those that were not. As long as the two groups are similar in all respects except for the implementation of the specific project, observing the situation of those where the project was not implemented can provide a good estimate of the counterfactual.

In the case of this impact evaluation, we were interested in assessing the added-value of the digital component. That is, assessing the impact of a supported traditional animation approach complemented by the use of digital technologies, compared to traditional animation approaches alone. At baseline, working closely with partners and Oxfam staff enabled the identification of a comparison group of villages in which animators were active, but not part of the current project.

\subsubsection{Sampling strategy of villages and animators}

As the project was taking place in 62 villages across four regions, random sampling of villages, stratified by region was carried out: up to six villages per region were randomly selected, maximizing the number of wards covered. ${ }^{7}$ Note that because of delays in implementation and sensitivity in carrying out surveys in the Nduta camp, it was agreed that the quantitative component would focus on the host communities in Kigoma. 
A comparison group of villages was identified where Chukua Hatua, or another governance project relying on traditional animation approaches (Lindi rural), was implemented, ${ }^{8}$ but no digital component was introduced in $2017 . .^{9}$ In addition, only villages in which a $2 \mathrm{G}$ or $3 \mathrm{G}$ connection was available were included, and villages in which animators were still active, could read and write, were not political or government leaders and were still resident of the village (a first screening of the animator lists was done with partners). Within sampled villages, animators were randomly sampled from the list of animators provided by partners and Oxfam. ${ }^{10}$

\subsubsection{Sampling strategy of women and men citizens}

The sample of citizens identified at baseline forms a representative sample in each village. First, random sampling of households was done using list of households available at the village executive office:11 then the gender of the respondents to the survey within the selected household was determined by randomly allocating the enumerator in charge of the survey: men enumerators would survey men respondents, and women enumerators, women respondents. The pairing of gender of enumerators and respondents was done to take into account the gender dynamics in the interviewee-interviewer relationship. This strategy was developed to form a representative sample of women and men citizens of different ages. More details on the sampling strategy can be found in the baseline report (Gismondi \& Pretari, 2018).

The sample established at baseline for this analysis is presented in Table 3.1.

Table 3.1: Sample established at baseline

\begin{tabular}{|c|c|c|c|c|c|c|c|c|c|}
\hline & & Intervention & 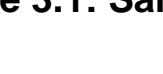 & (a) & Comparisol & the & & Overall & \\
\hline Region & $\begin{array}{l}\# \\
\text { Villages }\end{array}$ & $\begin{array}{l}\# \\
\text { animators } \\
\text { surveyed }\end{array}$ & $\begin{array}{l}\# \\
\text { citizens } \\
\text { surveyed }\end{array}$ & $\begin{array}{l}\# \\
\text { Villages }\end{array}$ & $\begin{array}{l}\# \\
\text { animators } \\
\text { surveyed }\end{array}$ & $\begin{array}{l}\# \\
\text { citizens } \\
\text { surveyed }\end{array}$ & $\begin{array}{l}\# \\
\text { Villages }\end{array}$ & $\begin{array}{l}\text { \# } \\
\text { animators } \\
\text { surveyed }\end{array}$ & $\begin{array}{l}\# \\
\text { citizens } \\
\text { surveyed }\end{array}$ \\
\hline Geita & 5 & 8 & 133 & 4 & 5 & 120 & 9 & 13 & 253 \\
\hline Arusha & 6 & 13 & 157 & 3 & 12 & 132 & 9 & 25 & 289 \\
\hline Mtwara/Lindi & 5 & 10 & 150 & 5 & 13 & 131 & 10 & 23 & 281 \\
\hline Kigoma - Host & 3 & 10 & 78 & & & & & 10 & 78 \\
\hline Total \# & 19 & 41 & 518 & 12 & 30 & 383 & 28 & 71 & 901 \\
\hline
\end{tabular}

\subsubsection{Data collection}

The quantitative analysis presented in this report relies on data gathered at baseline and at endline with citizens and animators.

The design of the baseline survey was presented in the baseline report (see Gismondi \& Pretari, 2018). The endline survey built on the baseline one, and additional research and testing was done to develop the following modules:

- Gathering stories of mobilization, self-signified by the respondents themselves (building on the SenseMaker methodology, developed by Cognitive Edge ${ }^{12}$ )

- Knowledge of rights, assessed through a series of true/false questions; because enumerators were trained to give information on the rights included in the baseline module, the endline one had to be different (see Appendix 2 for the baseline and endline details)

- Access to and improvement of social services and current state of human rights violation

- Use of social media, drawing from the questionnaires developed by Research ICT Africa. ${ }^{13}$

Baseline and endline surveys were tested in collaboration with, and implemented by, Ravens Consulting. A team of 16 surveyors, half women half men, and four supervisors were recruited 
for each survey. Trainings took place in September 2017 and February 2019, in Dodoma, for three days for each training, followed by one day of field testing.

At endline, 77 percent of the baseline citizens were surveyed ${ }^{14}$ and 87 percent of the baseline animators.

\subsubsection{Population description and quality of the comparison group}

The project population is described in detail in the baseline report (Gismondi \& Pretari, 2018). Appendix 1 presents the characteristics of animators and citizens in the comparison and intervention groups, testing for the significance of the difference (t-test of equality of the means). We present here the key differences and similarities between the two groups.

\section{Animators' characteristics (see Table A1.115)}

Because the comparison group was recruited out of former Chukua Hatua animators, or animators currently engaged in another Oxfam project, the observed differences seem to reflect the following:

- Differences in the selection processes of these projects compared to the one under review that we could not account for at time of sampling - both targeting and selfselection; for example, 6 percent of animators are teachers in the comparison group, while none are teachers in the intervention group, and Chukua Hatua indeed targeted teachers as animators in one of the phases of the project. Also, a larger share of animators had used a computer or a smartphone at baseline in the intervention group than in the comparison group.

- Differences in their journey as animator: ${ }^{16}$ animators are older on average in the comparison group (39 vs 34), less likely to have completed primary education (27 percent vs 51 percent) and more likely to be married (83 percent vs 61 percent) than animators in the intervention group; they are also less likely to have received support to carry out animation activities in the comparison group than in the intervention group. Similarly, 17 percent of animators in the comparison group were not reached at endline, while this is true for only 10 percent in the intervention group, which reflects potential disengagement overtime.

What is critical for the rest of the analysis is the fact that on average, at baseline, intervention animators were as likely to be involved in activities with citizens and/or officials as comparison group animators: between September 2016 and August 2017, 65 percent met up with citizens to talk about rights, 25 percent organized meeting with citizens, 15 percent organized meetings with citizens and officials, 79 percent participated in village meetings (instituted by law). However, animators in the intervention group were more involved in activities related to coordinating with others than those in the comparison group: animators were more likely to have sent out a message to others to elicit a speedy response, to have updated each other in case of an emergency and to have discussed something with other animators outside of the village, for example.

It is interesting to note that animators in the intervention group were also slightly less likely to have trust in village institutions, and more likely to identify the lack of response from government as a challenge in carrying out animation activities moving forward, than those in the comparison group. However, both groups of animators were as likely to be willing to keep organizing/facilitating discussions within the village moving forward (96 percent).

\section{Citizens' characteristics (see Table A1.2)}

Overall, citizens in the comparison and intervention groups had similar characteristics at baseline. We highlight here a few differences that may be associated with the outcomes under review. 
First, there is a larger share of respondents who know how to read and write in the intervention group (70 percent vs 56 percent). Based on an asset-based measure of wealth ${ }^{17}$ across the survey sample, we notice that a larger share of citizens in the comparison group are in the first quintile of the wealth distribution than in the intervention group (32 vs 14 percent), which reflects regional disparities (overall citizens in Kigoma region are less likely to be in this first quintile - only 10 percent are - and the comparison group does not include villages in Kigoma). Second, there is a larger share of respondents who participated in any group in the intervention group (54 percent vs 40 percent), and those who participate are slightly more likely to take part in the decision making of the group (on average, participating in the decision making of 1 group vs 0.8 ). Finally, among those who know any person playing the role of the animator, 35 percent were comfortable to a small or very small extent with the idea of the animator using a smartphone in the intervention group, against 17 percent in the comparison group.

Note that attrition is balanced across the two groups and within each region.

Lastly, as shown in the baseline report, differences at baseline between women and men citizens are important, and in particular on engagement with animators and with civic activities, access to information, knowledge of rights, or confidence in contesting a decision made in a public forum.

\subsubsection{Analysis}

In spite of the comparability of villages, and animators and citizens being part of the sampling strategy, there still are observable differences between the intervention and comparison groups, as presented in Section 3.2.4. Observable differences are corrected in this report by using a difference-in-differences approach, propensity-score matching (PSM) or multivariate regressions. The clustered nature of the data and of the project (intervention at the village level) is taken into account through regular clustering at village level.

\section{At animator level}

First, it is important to highlight that the analyses conducted on the animator sample are carried out on a very small sample of observations, by statistical standards. This means that only large-size effects will have a chance of being considered statistically significant. This also means that there is a risk of the observed effects being very specific to the sample we are basing the analysis on (if a few animators have very specific behaviours, they will influence the analysis a lot more than if the sample had been of larger size). However, the sample is representative of the population of animators (see Section 3.2.1).

Difference-in-differences is used when outcomes are measured at baseline and endline. It compares the trend of change in both groups and assumes that the (unobserved) trend (before baseline) is the same in each group. Difference-in-differences is used for estimates at animator level, using panel data and the following specification:

$$
Y_{i t p}=a+b . \text { Time }+c . \text { Project }+d . \text { Time } * \text { Project }+\varepsilon_{i t p}
$$

$Y$ is the outcome variable measured at baseline and endline, Time is a dummy variable taking the value 0 for baseline, 1 for endline and Project is a dummy variable taking the value 0 for comparison areas, 1 for project areas. Using multivariate regressions, we estimate $b$ - the trend of change over time in the comparison group, $c$ - the differences at baseline between comparison and intervention groups, and $d$-the difference-in-differences estimator, that is the impact of the project. We report these coefficients in the tables, as well as the average value of the outcome $Y$ at baseline in each group.

When the outcome of interest was not measured at baseline, simple multivariate regressions with control variables are used.

$$
Y_{i p}=a+b . \text { Project }+c . Z+\varepsilon_{i p}
$$

Governance and Accountability through Digitalization in Tanzania

Impact Evaluation 2017-2019 
$Z$ is a vector of control variables; we include key variables likely to determine the outcome: computer and smartphone usage before baseline, and age at baseline. We report $b$ in the tables below, as well as the average value of the outcome $Y$ at endline in the comparison group.

\section{At citizen level}

The difference-in-differences estimates following Model 1 are calculated as robustness checks (tables not shown; available upon request). The estimates presented in this report correct for imbalances at baseline on a few covariates to improve precision of the estimates through baseline control variables. The model is as follows:

$$
Y_{i t p}=a+b . \text { Time }+c . \text { Project }+d . \text { Time } * \text { Project }+e . Z+\varepsilon_{i t p}
$$

In particular, we control for regional variation, variation in animator characteristics and activism (to further account for the differences highlighted in Section 3.2.4), and variation in citizen characteristics. ${ }^{18}$ Hence $Z$ includes dummy variables for being in Arusha or Geita regions (former Chukua Hatua regions), the average age of animators in the village at baseline, a score of activities per animator per village, a score of support received per animator per village, citizens' literacy, citizens' participation in any group at baseline, number of groups in which they have a say in decision making, and whether they felt comfortable with the animator using a smartphone to do animation at baseline. Similarly, as for Model 1, the tables in the report present coefficients $b, c$ and $d$, as well as the average value of the outcome $Y$ at baseline in each group.

PSM is used when the outcomes of interest were measured at endline only. PSM corrects for observable differences at baseline between the two groups by matching citizens living in project areas with citizens living in comparison areas based on the similarity of their characteristics, and to obtain the project treatment effect by averaging the differences in outcomes across the two matched groups after project completion; the full matching procedure is detailed in Appendix 3. We will refer to it as Model 4 in the report.

Differential impacts among women and men citizens are systematically investigated and commented in the report; the tables are presented only when statistically significant differential impacts are observed.

When the overall average impact is estimated through difference-in-differences (Model 3), differential impacts are estimated and tested through a triple difference. The specification is as follows:

$$
\begin{gathered}
Y_{i t p}=a+b . \text { Gender }+c . \text { Time }+ \text { d.Project }+ \text { e.Gender } * \text { Project }+f . \text { Gender } * \text { Time }+ \text { g.Time } \\
* \text { Project }+ \text { h.Gender } * \text { Time } * \text { Project }+i . Z+\varepsilon_{i t p}
\end{gathered}
$$

In this case, $a$ is the constant (being a man at baseline in the comparison area), $b$ is the effect of being a woman in the comparison group at baseline, compared to being a man, $e$ becomes the additional effect of being a woman compared to being a man at baseline in the intervention group ( $b+e$ gives the overall effect of being a woman at baseline, compared to being a man, both groups together), $g$ is the impact of the project among men, $h$ the additional impact for women compared to men; $h$ tests for the significance of the difference. In this case, the tables report $b, e, g$ and $h$.

When the overall impact is estimated through PSM, differential impacts are estimated and tested through PS weighted multivariate regressions with interaction terms, controlling for the matching variables. The specification is as follows:

$$
Y_{i p}=a+b . \text { Gender }+c . \text { Project }+d . \text { Gender } * \text { Project }+e . X+\varepsilon_{i p}
$$

Following the example of Hirano and Imbens (2001) we weight the observations according to the propensity score. Observations are assigned weights equal to one for the citizens in 
intervention villages and $\hat{P}\left(\boldsymbol{X}_{\boldsymbol{i}}\right) /\left(1-\hat{P}\left(\boldsymbol{X}_{\boldsymbol{i}}\right)\right)$ for the citizens in comparison villages. The variable $\hat{P}\left(\boldsymbol{X}_{\boldsymbol{i}}\right)$ represents the probability of a citizen being in the intervention group, given their observable characteristics, measured through the vector of matching variables $\boldsymbol{X}_{\boldsymbol{i}}-$ this was estimated in the probit regressions in Appendix 3. We report estimates of $b$ - the effect of being a woman compared to being a man in the comparison group, $c$ - the impact of the project among men, $d$-the additional impact of the project for women, which provides a test of significance of the differential impact. Note $c+d$ provides the overall impact of the project for women.

\section{Same trend assumption}

A key assumption behind the use of difference-in-differences models is that the trend of change in the comparison group is a good estimate of the trend of change that would have taken place in the intervention group, in the absence of the project. We do not have data before baseline to test for this assumption. The differences highlighted in Section 3.2.4 between the intervention and comparison animators, which are particularly strong among former Chukua Hatua animators in Geita and Arusha and seem to reflect the differences in animators' journey, may have two different consequences on the same trend assumption.

First, the animators that were successfully reached in order to be included in the survey sample at baseline may be the highly motivated ones, not interested in politics, and still active a few years after the project they were part of started. This would lead to an underestimate of the project's impact. Indeed at baseline, among former Chukua Hatua animators and in Geita in particular, it was difficult to identify animators who were still active, living in the village and not doing politics.

Second, and by contrast, animators may be at risk of disengagement over time and that risk may be stronger in the comparison group than it would have been in the intervention group in the absence of the intervention, given that they have been animators for a longer time, without support. The difficulties in reaching some of them at the time of the endline survey, as well as some of the downward trends observed in the analysis (see Table 4.6 for example), seem to confirm the potential for disengagement over time. This would lead to an overestimate of the project's impact.

Overall, it is hard to conclude how this affects the trend of change in the comparison group and validates or invalidates the same trend assumption. However, as presented above, at citizen level, Model 5 takes into account some of the differences in animators' characteristics and activism at baseline.

\subsection{QUALITATIVE CASE STUDIES}

\section{Authors: Esther Towo, Benson Ndiege, Ezra Wango and Mwanahawa Mhina}

Four villages were used as case studies. Villages with a higher level of mobilization and outcomes related to the promotion of human rights and access to social services, active interaction and visible changes were selected. Thereafter, the villages that had improved relationships between local government duty bearers (district, ward and village), animators and citizens were included. In addition, villages with both men and women animators were given priority. The case studies aimed at drawing a deeper and more nuanced picture of the project's mechanisms and enablers, learning from best examples.

The case studies concentrated on two regions - Kigoma and Arusha - because of costeffectiveness, time consciousness and efficiency. Kigoma was selected because it was the first example of having such a project which used animators and had the unique case of a refugees' camp. Moreover, Arusha had experience with the Chukua Hatua project, which used animators and was convenient to the consultants. Thus, the two regions were useful in making generalizations for the evaluation. The consultants had a discussion with Oxfam staff in Arusha and Kigoma and the project partner in Arusha to identify the four villages based on 
the above criteria. In the rest of this report, Villages $A$ and $B$ refer to villages in Arusha, village $C$ refers to a village in Kigoma and Area $D$ to an area in the Nduta refugee camp.

Focus group discussions (FGDs), key informant interviews and documentary review, were used in data collection. The FGDs were used to collect data from the citizens. Sixteen FGDs were conducted, four from each case. For each case the FGD comprised four groups, which were elderly men, elderly women, male youth and female youth. The key informant interviewees included Oxfam staff and partners, village leaders and animators. ${ }^{19}$

\subsection{TWITTER DATA ANALYSIS}

\section{Authors: Nicole Schwitter and Ulf Liebe}

The following section presents the Twitter data harvested and analysed for this project.

Twitter is a real-time social networking and information service used to share messages. The aim of the analysis is to capture and describe animators' and influencers' behaviour and interactions on Twitter.

\subsubsection{Description of user data}

The Twitter analysis presented in Section 4.3 of this report relies on Twitter data collected on 12 December 2018 and 2 May 2019. It was attempted to collect the complete Twitter activity of all of the 196 animators and influencers. However, 13 Twitter handles referred to profiles that did not exist, so user data of only 181 profiles was retrieved. While this only affected a small number of Twitter accounts in most regions, almost one fifth of accounts are missing for Kigoma, which might influence the data if these are systematic losses (for example, it might be that primarily non-active Twitter users have misremembered their Twitter handle). Past tweets were retrieved for a total of 169 Twitter users. The 12 users for which no tweet data could be obtained either had a private profile, which could not be accessed, or have never tweeted (see Table 3.2).

Table 3.2: Users in the dataset

\begin{tabular}{lllllll}
\hline Users & Mtwara & Geita & Arusha & Kigoma & Influencer & Total \\
\hline List & 50 & 48 & 42 & 26 & 28 & 194 \\
\hline Profile Information & 49 & 45 & 42 & 21 & 24 & 181 \\
\hline Tweets & 45 & 42 & 40 & 18 & 24 & 169 \\
\hline
\end{tabular}

Collecting data on all Twitter accounts has the advantage of providing information from users from the entire project.

\subsubsection{Description of tweet data}

The timelines of 169 active Twitter users were retrieved. Twitter allows the collection of up to 3,200 most recent tweets from a public user's individual timeline. This restriction is especially relevant for some of the influencers which are highly active and with the most active one having posted a total of 230,224 times. Only a small, time-restricted part of this activity could be captured.

Data collection was performed twice for this analysis. If the limit of 3,200 tweets has not been reached by users, tweets that had been retrieved in the first round of data collection were retrieved again the second time (this is the case for all users in Geita, Arusha und Kigoma. See Table 3.3). However, for extremely active users, most tweets collected in May 2019 were new tweets, having been posted after December 2018. For users that reached the previously 3,200 maximum, parts of their Twitter activity between December 2018 and May 2019 was missing. This affects 19 of the 24 influencers and one animator from Mtwara. In total, details of 134,105 unique tweets were collected. 
The large majority of tweets in the dataset come from the 24 influencers. For the animators, it is notable that Kigoma shows very high activity on Twitter, despite having the smallest number of active Twitter users.

Table 3.3: Tweets in the dataset

\begin{tabular}{lllllll} 
Tweets & Mtwara & Geita & Arusha & Kigoma & Influencer & Total \\
\hline $\mathbf{2 0 1 8 - 1 2 - 1 2}$ & 4,535 & 2,144 & 979 & 5,179 & 62,288 & $\mathbf{7 5 , 1 2 5}$ \\
$\mathbf{2 0 1 9 - 0 5 - 0 2}$ & 8,136 & 3,613 & 1,353 & 8,395 & 64,710 & $\mathbf{8 6 , 2 0 7}$ \\
Total (excludes duplicates) & 9,232 & 3,620 & 1,354 & 8,405 & 111,494 & $\mathbf{1 3 4 , 1 0 5}$ \\
\hline
\end{tabular}

The oldest tweets for the animators date back to May 2009 (influencers: August 2011), with a median in November 2018, meaning that 50 percent of the tweets have been posted in November 2018 and after (influencers: December 2018). The most recent tweets are from the day of the data collection. Due to the dynamic nature of digital platforms, ever-changing in their purpose and usage, the dataset will be restricted to tweets posted after April 2017 for the main analysis (Section 4.3.2 to 4.3.4). This restricts the dataset to 132,279 tweets. 


\section{RESULTS \\ 4.1 ANALYSIS OF QUANTITATIVE IMPACT AT CITIZEN AND ANIMATOR LEVELS}

\subsubsection{Animation practices ${ }^{20}$}

As a result of the project, animators are significantly more likely to own a smartphone at the time of the endline than traditional animators: after correcting for trends in changes among animators in the comparison group and baseline differences, we observe a 43 percentage point positive difference in smartphone ownership and a 53 percentage point increase in smartphone use in the last 12 months. This is shown in Table 4.1. At baseline, 46 percent of animators in the intervention group reported having a smartphone, compared to 16 percent in the comparison group. 18 months after the project started 89 percent of animators involved in the project had a smartphone compared with 16 percent in the comparison group (no change over time in the comparison group). This is a measurable positive and significant impact of 43 percentage points in smartphone ownership that is attributable to the project. In the rest of the report, we comment on the change in outcome attributable to the project ('Impact of the project' in the tables, coefficient of the variable Time*Project as presented in Section 3.2.5), as well as the average at baseline in the intervention group.

Overall, the project did not enable more animators to receive information from an external source that helped raise awareness in the community in a significantly different way than in the comparison group. More animators, however, have received other types of external support (increase in 30 percentage points, significant at 5 percent) in the last 12 months.

Table 4.1: Project's inputs - animator level

\begin{tabular}{|c|c|c|c|c|}
\hline & $\begin{array}{c}\text { Owned } \\
\text { (personally) a } \\
\text { smartphone }\end{array}$ & $\begin{array}{l}\text { Has used a } \\
\text { smartphone }\end{array}$ & $\begin{array}{c}\text { Received any } \\
\text { information from } \\
\text { an external } \\
\text { source that } \\
\text { helped you raise } \\
\text { awareness } \\
\end{array}$ & $\begin{array}{c}\text { Received } \\
\text { other external } \\
\text { support }\end{array}$ \\
\hline Effect of time in the comparison group (Time) & $\begin{array}{c}-0 \\
(0.0583)\end{array}$ & $\begin{array}{l}-0.0400 \\
(0.0737)\end{array}$ & $\begin{array}{c}0.0800 \\
(0.0952)\end{array}$ & $\begin{array}{c}0 \\
(0.0583)\end{array}$ \\
\hline $\begin{array}{l}\text { Effect of being in the intervention group at } \\
\text { baseline (Project) }\end{array}$ & $\begin{array}{c}0.299^{\star * *} \\
(0.112)\end{array}$ & $\begin{array}{c}0.326^{* * *} \\
(0.116)\end{array}$ & $\begin{array}{l}0.301^{* *} \\
(0.121)\end{array}$ & $\begin{array}{l}0.257^{* * *} \\
(0.0938)\end{array}$ \\
\hline Impact of the project (Time ${ }^{*}$ Project) & $\begin{array}{c}0.432^{* * *} \\
(0.105)\end{array}$ & $\begin{array}{c}0.526^{* * *} \\
(0.125)\end{array}$ & $\begin{array}{c}0.109 \\
(0.138)\end{array}$ & $\begin{array}{l}0.297^{* *} \\
(0.121)\end{array}$ \\
\hline Observations & 124 & 124 & 124 & 124 \\
\hline Number of animators & 62 & 62 & 62 & 62 \\
\hline Mean at baseline in the comparison group & 0.160 & 0.160 & 0.240 & 0.0400 \\
\hline Mean at baseline in the intervention group & 0.459 & 0.486 & 0.541 & 0.297 \\
\hline
\end{tabular}

Robust standard errors in parentheses

${ }^{* * *} p<0.01,{ }^{* *} p<0.05,{ }^{*} p<0.1$

Difference-in-differences with village level

clustered standard errors (Model 1) 
As a result of the project, we observe a large increase in usage of social media by animators (increase of 72 percentage points), as shown in Table 4.2. This can be broken down in usage of Facebook (increase of 62 percentage points), usage of WhatsApp (increase of 71 percentage points), usage of Twitter (increase of 73 percentage points) and of other social media (increase of 10 percentage points, although not significant). Note that the shares of usage of these platforms are indeed very low in the comparison group: 20 percent of animators use social media in the comparison group, 20 percent use Facebook, 16 percent use WhatsApp and only 8 percent use Twitter or other social media.

Table 4.2: Animator's use of social media at endline

\begin{tabular}{lccccc}
\hline & & & & & Uses \\
& $\begin{array}{c}\text { Has social } \\
\text { media }\end{array}$ & $\begin{array}{c}\text { Uses } \\
\text { Facebook }\end{array}$ & $\begin{array}{c}\text { Uses } \\
\text { WhatsApp }\end{array}$ & $\begin{array}{c}\text { Uses } \\
\text { Twitter }\end{array}$ & $\begin{array}{c}\text { social } \\
\text { media }\end{array}$ \\
\hline Impact of the project (Project) & & & & & \\
& $0.717^{* * *}$ & $0.622^{* * *}$ & $0.709^{* * *}$ & $0.728^{* * *}$ & 0.101 \\
& $(0.0986)$ & $(0.103)$ & $(0.107)$ & $(0.122)$ & $(0.116)$ \\
Observations & 62 & 62 & 62 & 62 & 62 \\
R-squared & 0.664 & 0.592 & 0.628 & 0.623 & 0.111 \\
Mean at endline in the comparison group & 0.200 & 0.200 & 0.160 & 0.0800 & 0.0800 \\
\hline
\end{tabular}

Robust standard errors in parentheses

${ }^{* * *} p<0.01,{ }^{* *} p<0.05,{ }^{*} p<0.1$

Multivariate regression with baseline control variables (Model 2)

This increase in social media use as a result of the project also translates into a significant increase in using social media to be part of conversations with leaders or officials, in being part of a WhatsApp group or of a Facebook group on local issues, and in following animators on Twitter, on average. Indeed Table 4.3 shows a statistically significant and large effect size, with a very low share of animators in the comparison group using such platforms: in the comparison group at endline, only 16 percent of animators regularly use social media to be part of conversations with leaders or officials, 12 percent are part of a WhatsApp group and 4 percent on a Facebook group on a local issue, and 8 percent follow animators in Twitter. Similarly, shares of usage are very low in the comparison group. Among animators who are using social media, the project significantly increased the share of animators who are part of a Facebook group on local issues (an increase of 68 percentage points - table not shown; available upon request), keeping the other usage and behaviours similar across both groups.

Table 4.3: Animators' use of social media for activism

\begin{tabular}{|c|c|c|c|c|}
\hline & $\begin{array}{l}\text { Use social media to be } \\
\text { part of conversations } \\
\text { with leaders or officials } \\
\text { - At least once a week }\end{array}$ & $\begin{array}{l}\text { Being part } \\
\text { of a } \\
\text { WhatsApp } \\
\text { group on } \\
\text { local } \\
\text { issues } \\
\end{array}$ & $\begin{array}{c}\text { Being part } \\
\text { of a } \\
\text { Facebook } \\
\text { group on } \\
\text { local } \\
\text { issues }\end{array}$ & $\begin{array}{l}\text { Following } \\
\text { animators } \\
\text { on Twitter }\end{array}$ \\
\hline Impact of the project (Project) & $\begin{array}{c}0.492^{* * *} \\
(0.141)\end{array}$ & $\begin{array}{c}0.731^{* * *} \\
(0.112)\end{array}$ & $\begin{array}{c}0.649^{* * *} \\
(0.115)\end{array}$ & $\begin{array}{c}0.702^{* * *} \\
(0.124)\end{array}$ \\
\hline Observations & 62 & 62 & 62 & 62 \\
\hline $\begin{array}{l}\text { R-squared } \\
\text { Mean at endline in the comparison }\end{array}$ & 0.328 & 0.616 & 0.527 & 0.573 \\
\hline
\end{tabular}

Robust standard errors in parentheses

${ }^{* * *} p<0.01,{ }^{* *} p<0.05,{ }^{*} p<0.1$

Multivariate regression with baseline control variables (Model 2)

Governance and Accountability through Digitalization in Tanzania Impact Evaluation 2017-2019 
In addition, we observe an increase in offline activities initiated by the animators towards the citizens as a result of the project and compared to traditional animators (Table 4.4). More animators met up with citizens (increase of 38 percentage points, with 65 percent of animators meeting with citizens at baseline in the intervention group, and a slight nonsignificant decrease over time in the comparison group), organized meetings with citizens without officials (increase of 44 percentage points, with 24 percent of animators doing so in the intervention group at baseline), organized meetings with citizens and officials (increase of 38 percentage points, with 19 percent of animators doing so in the intervention group at baseline). Participation of animators in village meetings (instituted by law) is not significantly affected: 84 percent of animators at baseline in the intervention group had participated in the village by law meeting in the last 12 months and 86 percent at endline. The qualitative case studies (Towo et al., 2019) highlight the importance of animators' participation in the village meeting as a space to advocate and hold village leaders accountable. Hence, in village $C$, an animator said that 'The Halotel Company ceased to pay rent due to land ownership misunderstanding between the village and a community member. We twitted the saga and tagged the deputy minister responsible for communication. We made follow up through village meetings until the problem was solved'. Another animator added that 'We discussed in the meeting the need for a maternity ward in the village dispensary. The meeting agreed on the matter and the money has been set aside.'

Table 4.4: Animators' offline activities

\begin{tabular}{|c|c|c|c|c|}
\hline & $\begin{array}{l}\text { Met up with } \\
\text { citizens to } \\
\text { discuss }\end{array}$ & $\begin{array}{l}\text { Organized } \\
\text { meetings with } \\
\text { citizens } \\
\text { (without } \\
\text { officials) }\end{array}$ & $\begin{array}{l}\text { Organized } \\
\text { meetings } \\
\text { with } \\
\text { citizens } \\
\text { and } \\
\text { officials }\end{array}$ & $\begin{array}{l}\text { Participated } \\
\text { in village } \\
\text { meetings } \\
\text { (instituted } \\
\text { by law) }\end{array}$ \\
\hline Effect of time in the comparison group (Time) & $\begin{array}{l}-0.0800 \\
(0.114)\end{array}$ & $\begin{array}{l}-0.120 \\
(0.0835)\end{array}$ & $\begin{array}{l}0.160^{* * *} \\
(0.0477)\end{array}$ & $\begin{array}{l}-0.0800 \\
(0.0980)\end{array}$ \\
\hline $\begin{array}{l}\text { Effect of being in the intervention group at baseline } \\
\text { (Project) }\end{array}$ & $\begin{array}{c}0.00865 \\
(0.134)\end{array}$ & $\begin{array}{l}-0.0768 \\
(0.132)\end{array}$ & $\begin{array}{c}0.109 \\
(0.0795)\end{array}$ & $\begin{array}{l}0.0778 \\
(0.116)\end{array}$ \\
\hline Impact of the project (Time ${ }^{*}$ Project) & $\begin{array}{l}0.377^{* *} \\
(0.147)\end{array}$ & $\begin{array}{c}0.444^{* * *} \\
(0.128)\end{array}$ & $\begin{array}{c}0.381^{* * *} \\
(0.109)\end{array}$ & $\begin{array}{l}0.107 \\
(0.116)\end{array}$ \\
\hline Observations & 124 & 124 & 124 & 124 \\
\hline Number of animators & 62 & 62 & 62 & 62 \\
\hline Mean at baseline in the comparison group & 0.640 & 0.320 & 0.0800 & 0.760 \\
\hline Mean at baseline in the intervention group & 0.649 & 0.243 & 0.189 & 0.838 \\
\hline
\end{tabular}

Robust standard errors in parentheses

${ }^{* * *} p<0.01,{ }^{* *} p<0.05,{ }^{*} p<0.1$

Difference-in-differences with village level clustered standard errors (Model 1)

As a result of the project, significantly more animators are connected with other animators, compared to animators in the comparison group: Table 4.5 shows an increase of 34 percentage points in the share of animators who discussed issues related to rights or access to services with other animator(s) within the village in the last 12 months, while 70 percent of animators doing so at baseline in the intervention group and a slight non-significant decrease in this share over time in the comparison group. It also shows an increase of 40 percentage points in the share of animators discussing such issues with other animator(s) outside the village in the last 12 months, while 59 percent of animators were doing so in the intervention group at baseline. 


\begin{tabular}{lcc}
\hline & $\begin{array}{c}\text { Discussed issues } \\
\text { related to rights or } \\
\text { access to services with } \\
\text { other animator(s) } \\
\text { within the village }\end{array}$ & $\begin{array}{c}\text { Discussed issues } \\
\text { related to rights or } \\
\text { access to services with } \\
\text { other animator(s) } \\
\text { outside of the village }\end{array}$ \\
\hline Effect of time in the comparison group (Time) & -0.0400 & -0.0800 \\
Effect of being in the intervention group at & $(0.107)$ & $(0.0734)$ \\
baseline (Project) & 0.0627 & $0.355^{* * *}$ \\
Impact of the project (Time*Project) & $(0.134)$ & $(0.131)$ \\
Observations & $0.337^{\star *}$ & $0.404^{* *}$ \\
Number of animators & $(0.144)$ & $(0.140)$ \\
Mean at baseline in the comparison group & 124 & 124 \\
Mean at baseline in the intervention group & 62 & 62 \\
\hline
\end{tabular}

Robust standard errors in parentheses

${ }^{\star * *} p<0.01,{ }^{* *} p<0.05,{ }^{*} p<0.1$

Difference-in-differences with village level clustered standard errors (Model 1)

Similarly, the project impacted animation practices (Table 4.6). In the last 12 months, the project enabled more animators to educate and share their skills and experiences with others (increase of 43 percentage points), energize people to act with them and join action (increase of 50 percentage points), send out a message to elicit a speedy and organized response (32 percentage point increase, check with other animators or activists regularly (43 percentage point increase), update each other in case of emergency (28 percentage point increase, only significant at 10 percent level). Note that the trend is negative over time in the comparison group (table not shown; available upon request) - although significant for only one variable out of five, which reveals a risk of lassitude or disengagement among unsupported animators using the traditional approach, which the project was able to compensate for and more. 
Table 4.6: Animators' activism in the last 12 months

\begin{tabular}{|c|c|c|c|c|c|}
\hline & $\begin{array}{l}\text { Educated } \\
\text { and shared } \\
\text { your skills } \\
\text { and } \\
\text { experiences } \\
\text { with others }\end{array}$ & $\begin{array}{l}\text { Energized } \\
\text { people to } \\
\text { act with } \\
\text { you and } \\
\text { join action }\end{array}$ & $\begin{array}{l}\text { Sent out a } \\
\text { message } \\
\text { to elicit a } \\
\text { speedy } \\
\text { and } \\
\text { organized } \\
\text { response }\end{array}$ & $\begin{array}{l}\text { Checked } \\
\text { in with } \\
\text { other } \\
\text { animators } \\
\text { or } \\
\text { activists } \\
\text { regularly }\end{array}$ & $\begin{array}{c}\text { Updated } \\
\text { each other } \\
\text { in cases of } \\
\text { emergency }\end{array}$ \\
\hline Effect of time in the comparison group (Time) & $\begin{array}{l}-0.0800 \\
(0.0838)\end{array}$ & $\begin{array}{c}-0.280^{* * *} \\
(0.105)\end{array}$ & $\begin{array}{l}-0.0800 \\
(0.116)\end{array}$ & $\begin{array}{l}-0.160 \\
(0.128)\end{array}$ & $\begin{array}{l}-0.0400 \\
(0.107)\end{array}$ \\
\hline $\begin{array}{l}\text { Effect of being in the intervention group at baseline } \\
\text { (Project) }\end{array}$ & $\begin{array}{c}-0.151 \\
(0.0947)\end{array}$ & $\begin{array}{l}-0.0562 \\
(0.102)\end{array}$ & $\begin{array}{l}0.342^{* * *} \\
(0.128)\end{array}$ & $\begin{array}{l}0.00973 \\
(0.147)\end{array}$ & $\begin{array}{l}0.250^{* *} \\
(0.125)\end{array}$ \\
\hline Impact of the project (Time ${ }^{\star}$ Project) & $\begin{array}{c}0.431^{* * *} \\
(0.116)\end{array}$ & $\begin{array}{c}0.496^{* * *} \\
(0.136)\end{array}$ & $\begin{array}{l}0.323^{* *} \\
(0.153)\end{array}$ & $\begin{array}{l}0.430^{* * *} \\
(0.164)\end{array}$ & $\begin{array}{l}0.283^{*} \\
(0.149)\end{array}$ \\
\hline Observations & 124 & 124 & 124 & 124 & 124 \\
\hline Number of animators & 62 & 62 & 62 & 62 & 62 \\
\hline Mean at baseline in the comparison group & 0.800 & 0.840 & 0.280 & 0.720 & 0.480 \\
\hline Mean at baseline in the intervention group & 0.649 & 0.784 & 0.622 & 0.730 & 0.730 \\
\hline
\end{tabular}

Robust standard errors in parentheses

${ }^{* * *} p<0.01,{ }^{* *} p<0.05,{ }^{*} p<0.1$

Difference-in-differences with village level clustered standard errors (Model 1 )

We observe a similar (although small and not significant) negative trend over time in the comparison group when it comes to animators' willingness to keep organizing activities/facilitating discussions around rights in the future. The project impact is positive and significant: an increase of 13 percentage points in the share of animators who are willing to keep carrying out animation activities moving forward is observed (Table 4.7).

Table 4.7: Willingness to keep organizing in the future

\begin{tabular}{lc}
\hline & $\begin{array}{c}\text { Willing to keep organizing } \\
\text { activities/facilitating } \\
\text { discussions around rights } \\
\text { and access to social } \\
\text { services in the village }\end{array}$ \\
\hline Effect of time in the comparison group (Time) & -0.0800 \\
Effect of being in the intervention group at baseline (Project) & $(0.0530)$ \\
Impact of the project (Time*Project) & -0.0541 \\
& $(0.0352)$ \\
Observations & $0.134^{* *}$ \\
Number of animators & $(0.0636)$ \\
Mean at baseline in the comparison group & 124 \\
Mean at baseline in the intervention group & 62 \\
Robust standard & 1 \\
\end{tabular}

Robust standard errors in parentheses

${ }^{* * *} p<0.01,{ }^{* *} p<0.05,{ }^{*} p<0.1$

Difference-in-differences with village level clustered standard errors (Model 1)

Overall, animators consider that using the internet (through a smartphone or a computer) helps them (100 percent of animators who use social media or internet in the intervention group considered this to be the case). 
Finally, note that in both groups, half the animators are men, and half are women. Because of the size of the sample, we cannot test for differential changes in practices as a result of the project by gender of the animator. However, one key question of interest is how women experience being an animator because of social norms around women's public and political participation in public and private spaces. Of women in the intervention group, 89 percent considered that their relationship with village or hamlet officials had improved and 84 percent that their relationship with the village or hamlet leaders had improved $(n=19)$ (compared to 83 and 78 percent of men animators in the intervention group, $n=18$ ). In addition, 70 percent of women in the intervention group considered that their relationship with their partner had improved as a result of being an animator, and 30 percent that it had stayed the same (among men, 88 percent considered that the relationship with their partner had improved). In addition, the qualitative case studies did not highlight significantly different experiences for women and men animators.

\subsubsection{Citizens' engagement with animators}

\section{Offline engagement}

As a result of the project, citizens are more likely to know the animators: 24 percent of citizens knew any person playing the role of animator at baseline in the intervention group, and the project enabled an increase of 30 percentage points. However, the average citizen is as likely to engage with animators' offline activities in both groups (see Table 4.8). These effects are not significantly different for women and men citizens, although women are less likely than men to know animators, to be invited to participate in meetings organized by the animators and to have individual conversations with animators about their rights in the first place.

Table 4.8: Citizens' offline engagement with animators

\begin{tabular}{|c|c|c|c|c|c|}
\hline & $\begin{array}{l}\text { Know any } \\
\text { person } \\
\text { playing the } \\
\text { role of } \\
\text { animator in } \\
\text { your village }\end{array}$ & $\begin{array}{l}\text { Invited to } \\
\text { participate } \\
\text { in meetings } \\
\text { organized } \\
\text { by the } \\
\text { village } \\
\text { animators - } \\
\text { without } \\
\text { leaders }\end{array}$ & $\begin{array}{c}\text { Average } \\
\text { number of } \\
\text { participation } \\
\text { in meetings } \\
\text { organized } \\
\text { by the } \\
\text { village } \\
\text { animators - } \\
\text { without } \\
\text { leaders }\end{array}$ & $\begin{array}{l}\text { Spoke up } \\
\text { in THE } \\
\text { LAST } \\
\text { meetings } \\
\text { organized } \\
\text { by the } \\
\text { village } \\
\text { animators }\end{array}$ & $\begin{array}{c}\text { Had } \\
\text { individual } \\
\text { conversation } \\
\text { with } \\
\text { animators } \\
\text { (about } \\
\text { rights) } \\
\end{array}$ \\
\hline $\begin{array}{l}\text { Effect of time in the comparison group } \\
\text { (Time) }\end{array}$ & $\begin{array}{c}0.0498 \\
(0.0529)\end{array}$ & $\begin{array}{l}-0.0498^{*} \\
(0.0297)\end{array}$ & $\begin{array}{l}-0.216^{*} \\
(0.128)\end{array}$ & $\begin{array}{l}-0.0469^{*} \\
(0.0272)\end{array}$ & $\begin{array}{l}-0.00664 \\
(0.0182)\end{array}$ \\
\hline $\begin{array}{l}\text { Effect of being in the intervention group at } \\
\text { baseline (Project) }\end{array}$ & $\begin{array}{l}-0.107^{\star} \\
(0.0610)\end{array}$ & $\begin{array}{l}-0.0508 \\
(0.0525)\end{array}$ & $\begin{array}{l}-0.191 \\
(0.194)\end{array}$ & $\begin{array}{l}-0.0509 \\
(0.0469)\end{array}$ & $\begin{array}{l}-0.0147 \\
(0.0403)\end{array}$ \\
\hline Impact of the project (Time ${ }^{*}$ Project) & $\begin{array}{l}0.300^{* * *} \\
(0.0728)\end{array}$ & $\begin{array}{c}0.0699 \\
(0.0458)\end{array}$ & $\begin{array}{l}0.128 \\
(0.161)\end{array}$ & $\begin{array}{c}0.0291 \\
(0.0345)\end{array}$ & $\begin{array}{c}-0.000767 \\
(0.0262)\end{array}$ \\
\hline Observations & 1,404 & 1,404 & 1,403 & 1,399 & 1,404 \\
\hline Number of citizens & 702 & 702 & 702 & 702 & 702 \\
\hline Mean at baseline in the comparison group & 0.159 & 0.103 & 0.349 & 0.0733 & 0.0698 \\
\hline Mean at baseline in the intervention group & 0.237 & 0.162 & 0.446 & 0.0875 & 0.125 \\
\hline
\end{tabular}

Robust standard errors in parentheses

*** $p<0.01,{ }^{* *} p<0.05,{ }^{*} p<0.1$

Difference-in-differences with random effects, village level clustered standard errors and control variables as described in Section 3.2.5 (Model 3) 
To understand further what the characteristics of the citizens who know the animators at endline are, we used multivariate regressions. ${ }^{21}$ As mentioned above, women are significantly less likely to know the animators, considering all other characteristics in the model are constant. Citizens' age is not significantly associated with knowing the animator, nor is the average age of the animators in the village a determinant. However, citizens from Arusha and Geita are less likely than citizens from Kigoma and Mtwara to know the animator, considering all other characteristics in the model are constant (this association is stronger among men). Among men, the higher the number of groups where they are involved in decision making, the more likely they are to know the animators.

\section{Online engagement}

First, it is important to highlight that very few citizens have access to a smartphone: 7 percent at baseline in the intervention group personally owned a smartphone and 10 percent had ever used a smartphone at baseline (respectively 5 and 7 percent among women). The project did not significantly impact this. Note that the main reasons given by citizens in the project area for not using the internet are the lack of equipment (70 percent), the lack of knowledge on how (11 percent), the lack of time (11 percent) and the price (10 percent). ${ }^{22}$

Use of social media among citizens is not affected by the project, and the share of citizens who use social media is low: 15 percent of men and 6 percent of women in the intervention group (difference statistically significant), that is 10 percent of citizens overall.

The qualitative case studies highlight that in the two cases in Arusha, young adults were particularly interested in joining the social media platforms, or were already engaging with it: 'Many youth in the village were buying smartphones and join the village WhatsApp groups' according to the leader of village $A$. While in village $B$, a male youth said 'I once saw the message posted on Facebook page showing the issue of "village planning" and construction of classrooms', showing online engagement. The quantitative data shows that 11 percent of the citizens below 35 own a smartphone in the project areas at endline, and that 15 percent use social media, which is significantly higher than among the citizens above 35 .

When using multivariate regressions to better understand the citizens' characteristics that are associated with using social media, ${ }^{23}$ we confirm that women are less likely to have social media. Also, the older the citizen, the less likely they are to have access to social media, and as citizens get older, the effect of age is strengthened (even less likely to have access), considering all other characteristics in the model are constant. Citizens who know how to read and write are also more likely to have social media. This is also the case for citizens in the highest quintile of the wealth distribution, compared to citizens in other parts of the wealth distribution. Citizens from Arusha (compared to citizens from Mtwara or Kigoma) and citizens who knew animators at baseline, are more likely to have access to social medial. Note that these associations hold true among women and among men. In addition, women who participated in village meetings at baseline are less likely to have access to social media than the ones who did not. Participation in village meetings is positively associated with access to social media for men, although not statistically significant. On the other hand, the more groups men are involved in where they take decisions, the more likely they are to have access to social media. We don't see a similar pattern for women.

Among citizens who know animators in their village at endline, citizens in the intervention groups are as likely as those in the comparison group to be part of a WhatsApp group on local issues initiated by animators (3 percent in the intervention group), of a similar Facebook group (1 percent in the intervention group) and to follow the animators on Twitter (less than 1 percent). (Table not shown; available upon request.) 


\subsubsection{Citizens' engagement and participation}

\section{Citizens' 'power within' and 'power to'}

Drawing from the literature mentioned in Section 2.2, and from Lombardini, Bowman and Garwood (2017), we built multidimensional indices of 'power within' and 'power to' in order to assess whether the project made a difference in citizens' building of these, compared to a traditional approach. The construction of the indices is presented in Appendix 4.

Women and men in villages where the ICT-supported animation approach is ongoing are not developing their sense of 'power within' differently from women and men in villages where a traditional animation approach is ongoing (Table 4.9). However, we observed an impact of the project on 'power to' (significant at 10 percent). This impact is driven by a change in citizens' ability to decide for themselves about their participation in community activities, or travelling outside of the community (impact significant at 10 percent) and in their attitude towards public forums (more citizens disagree with the statement 'Public forums held in your village can be intimidating - it is difficult for someone like you to stand up and voice any concerns' and agree with the statement 'If a decision was made in a public forum which might negatively affect your life and those of your children, you would not hesitate to stand up and protest despite the possible negative consequences' - significant at 5 percent, see Table A4.3). While the observed impact of the project is not different between women and men, it is important to highlight that women have a significantly lower score of 'power to' than men to start with.

Table 4.9: Multi-dimensional indices of 'power within' and 'power to'

\begin{tabular}{lcc}
\hline & $\begin{array}{c}\text { 'Power within' } \\
\text { multidimensional index }\end{array}$ & $\begin{array}{c}\text { 'Power to' } \\
\text { multidimensional } \\
\text { index }\end{array}$ \\
\hline Effect of time in the comparison group (Time) & $0.0512^{*}$ & -0.00797 \\
& $(0.0272)$ & $(0.0225)$ \\
Effect of being in the intervention group at baseline & -0.0105 & $-0.0647^{\star * *}$ \\
(Project) & $(0.0258)$ & $(0.0168)$ \\
Impact of the project (Time*Project) & 0.0206 & $0.0554^{*}$ \\
& $(0.0359)$ & $(0.0311)$ \\
Observations & & \\
Number of citizens & 1,404 & 1,404 \\
Mean at baseline in the comparison group & 702 & 702 \\
Mean at baseline in the intervention group & 0.616 & 0.492 \\
\hline
\end{tabular}

Robust standard errors in parentheses

${ }^{* * *} p<0.01,{ }^{* *} p<0.05,{ }^{*} p<0.1$

Difference-in-differences with random effects, village level clustered standard errors and control variables as described in Section 3.2.5 (Model 3)

\section{'Power with': engagement with civic activities and actions undertaken by citizens}

While the case studies highlight that in the villages were the approach was the most successful, engagement with civic activities is strengthened (see Section 4.2.2), we do not measure a significant impact on citizens' participation in community dialogue with other citizens and officials at scale (Table 4.10). Thirty-four percent of citizens were invited to such meetings at baseline in the intervention group, and that was not significantly affected by the project. Note that when citizens are invited, they participate (less than 3 percent of those invited did not participate at baseline in the intervention group). Similarly, participation in village meetings is not significantly affected by the project, with three quarters of citizens having participated in village meetings in the intervention group, at baseline, in the previous twelve months. Project impacts are not different between women and men, but women are less likely to participate than men (70 percent of women participated in village meetings at baseline in the intervention group and 22 percent in community dialogue). 
Table 4.10: Citizens' participation in community dialogue and village meetings instituted by law (public spaces)

\begin{tabular}{lcc}
\hline & $\begin{array}{c}\text { Invited to participate in } \\
\text { meeting with citizens and } \\
\text { officials - community } \\
\text { dialogue }\end{array}$ & $\begin{array}{c}\text { Participated in village } \\
\text { meetings (instituted by } \\
\text { law) }\end{array}$ \\
\hline Effect of time in the comparison group (Time) & $0.110^{\star * *}$ & 0.0432 \\
Effect of being in the intervention group at & $(0.0214)$ & $(0.0325)$ \\
baseline (Project) & 0.0307 & -0.0307 \\
Impact of the project (Time*Project) & $(0.0381)$ & $(0.0507)$ \\
& 0.00997 & 0.0665 \\
Observations & $(0.0369)$ & $(0.0501)$ \\
Number of citizens & & 1,404 \\
Mean at baseline in the comparison group & 704 & 702 \\
Mean at baseline in the intervention group & 0.276 & 0.777 \\
\hline
\end{tabular}

Robust standard errors in parentheses

${ }^{* \star *} p<0.01,{ }^{* *} p<0.05,{ }^{*} p<0.1$

Difference-in-differences with random effects, village level clustered standard errors and control variables as described in Section 3.2.5 (Model 3)

Among citizens who participated in community dialogue in both groups, the project significantly impacted the topics discussed (Table 4.11): citizens in the project areas are more likely to have used these spaces to discuss issues related to water and sanitation (increase of 24 percentage points) and issues related to access to health services (increase of 20 percentage points, significant at 10 percent).

Table 4.11: Issues discussed in the last community dialogues citizen took part in, in the previous 12 months

\begin{tabular}{|c|c|c|c|c|c|}
\hline & $\begin{array}{l}\text { Land } \\
\text { rights }\end{array}$ & $\begin{array}{l}\text { Access } \\
\text { to water }\end{array}$ & $\begin{array}{l}\text { Access to } \\
\text { health } \\
\text { services }\end{array}$ & Education & Infrastructure \\
\hline $\begin{array}{l}\text { Effect of time in the comparison group } \\
\text { (Time) }\end{array}$ & $\begin{array}{l}-0.0601 \\
(0.0870)\end{array}$ & $\begin{array}{l}-0.167^{* *} \\
(0.0680)\end{array}$ & $\begin{array}{l}-0.0198 \\
(0.0880)\end{array}$ & $\begin{array}{l}-0.00900 \\
(0.0977)\end{array}$ & $\begin{array}{l}-0.0866 \\
(0.0615)\end{array}$ \\
\hline $\begin{array}{l}\text { Effect of being in the intervention group } \\
\text { at baseline (Project) }\end{array}$ & $\begin{array}{l}-0.0632 \\
(0.0912)\end{array}$ & $\begin{array}{c}0.280^{\star * *} \\
(0.0904)\end{array}$ & $\begin{array}{c}-0.290^{* * *} \\
(0.104)\end{array}$ & $\begin{array}{c}0.0613 \\
(0.0992)\end{array}$ & $\begin{array}{l}-0.0546 \\
(0.100)\end{array}$ \\
\hline Impact of the project (Time ${ }^{*}$ Project) & $\begin{array}{r}-0.0114 \\
(0.112)\end{array}$ & $\begin{array}{l}0.240^{* *} \\
(0.0958)\end{array}$ & $\begin{array}{l}0.198^{\star} \\
(0.103)\end{array}$ & $\begin{array}{l}0.0776 \\
(0.105)\end{array}$ & $\begin{array}{c}0.0918 \\
(0.0887)\end{array}$ \\
\hline $\begin{array}{l}\text { Observations } \\
\text { Number of icitizens } \\
\text { Mean at baseline in the comparison } \\
\text { group } \\
\text { Mean at baseline in the intervention } \\
\text { group }\end{array}$ & $\begin{array}{l}503 \\
380\end{array}$ & $\begin{array}{l}503 \\
380\end{array}$ & $\begin{array}{l}503 \\
380\end{array}$ & $\begin{array}{l}503 \\
380\end{array}$ & $\begin{array}{l}503 \\
380\end{array}$ \\
\hline
\end{tabular}

Robust standard errors in parentheses

*** $p<0.01,{ }^{* *} p<0.05,{ }^{*} p<0.1$

Difference-in-differences with random effects, village level clustered standard errors and control variables as described in Section 3.2.5 (Model 3) 
Note that Table 4.11 shows only the topics that were identified by at least 10 percent of citizens as having been discussed. Figure 4.1 shows the percentage of citizens who identified that a topic was discussed in the last community dialogue citizens took part in at endline in the intervention group $(n=178)$.

Figure 4.1: Topics discussed in community dialogues

\section{Topics discussed in the last community dialogue citizens took part in, intervention group at endline}

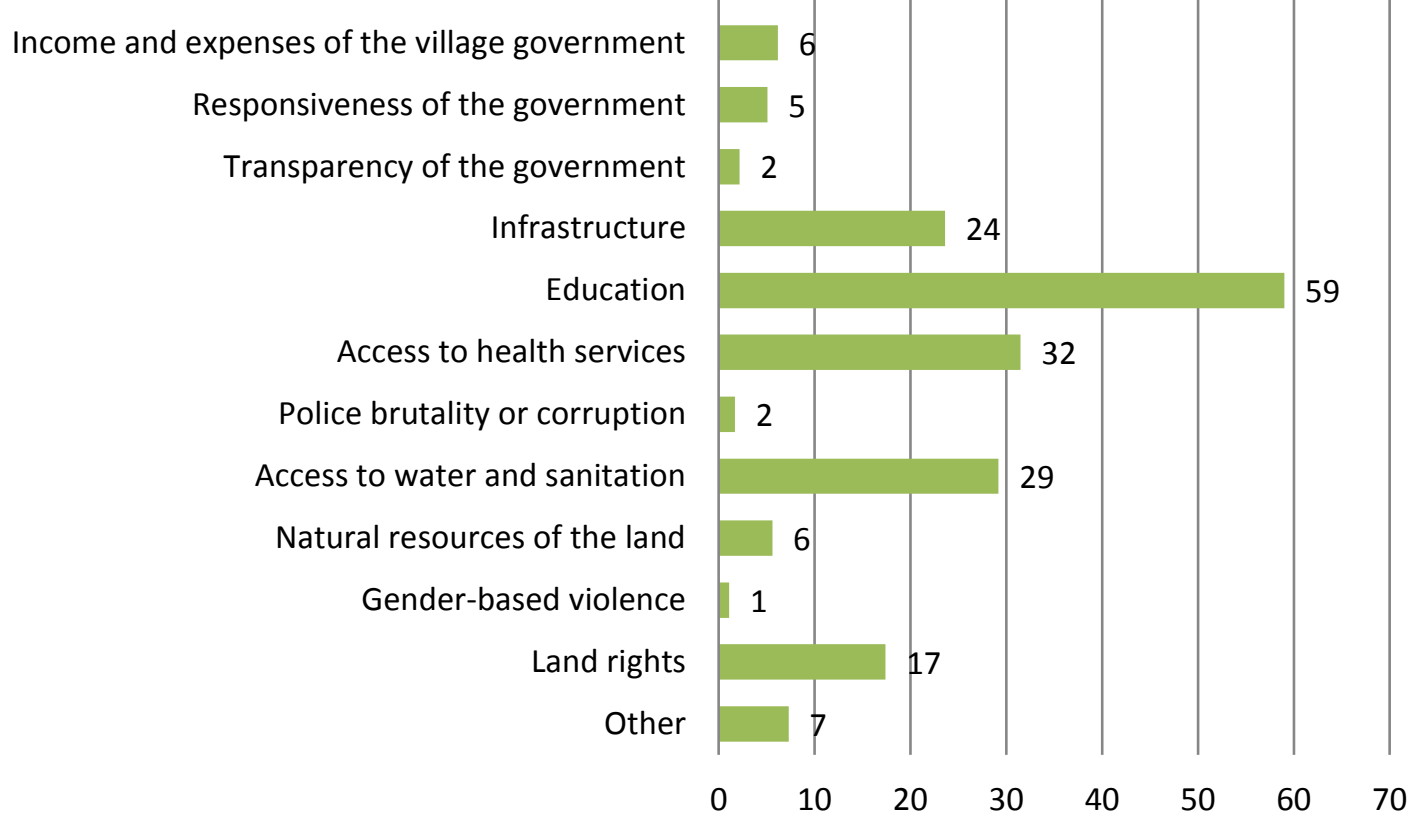

In the first phase of Chukua Hatua, the fact that citizens did not have access to discuss issues among themselves was identified as a limitation. ${ }^{24}$ Table 4.12 shows that 15 percent of citizens participated in meetings among themselves at baseline in the intervention group. The project is not significantly impacting this, compared to citizens in villages with a traditional approach to animation. Similarly, no significant impact was observed on the share of citizens reporting issues to local government authorities or to journalists. 
Table 4.12: Citizens' organizing and reporting (closed spaces)

\begin{tabular}{lcccc}
\hline & $\begin{array}{c}\text { Participated in } \\
\text { meetings with } \\
\text { citizens - without } \\
\text { any village } \\
\text { leaders/officials }\end{array}$ & $\begin{array}{c}\text { Reported any } \\
\text { issues to the } \\
\text { hamlet, village, } \\
\text { ward or district } \\
\text { leaders }\end{array}$ & $\begin{array}{c}\text { Reported any } \\
\text { issues to } \\
\text { journalists }\end{array}$ \\
\hline Effect of time in the comparison group (Time) & $-0.0498^{*}$ & 0.0565 & -0.00332 \\
Effect of being in the intervention group at & $(0.0298)$ & $(0.0360)$ & $(0.00570)$ \\
baseline (Project) & -0.0287 & 0.0170 & -0.00228 \\
Impact of the project (Time*Project) & $(0.0244)$ & $(0.0403)$ & $(0.00676)$ \\
& 0.0449 & -0.0689 & 0.00830 \\
Observations & $(0.0432)$ & $(0.0480)$ & $(0.00912)$ \\
Number of citizens & 1,404 & 1,404 & 1,404 \\
Mean at baseline in the comparison group & 702 & 702 & 702 \\
Mean at baseline in the intervention group & 0.143 & 0.226 & 0.0133 \\
\hline Robust standard erts & 0.147 & 0.272 & 0.00998 \\
\hline
\end{tabular}

Robust standard errors in parentheses

${ }^{* * *} p<0.01,{ }^{* *} p<0.05,{ }^{*} p<0.1$

Difference-in-differences with random effects, village level clustered standard errors and control variables as described in Section 3.2.5 (Model 3)

As a result of the project, citizens are more likely to report issues related to access to water, compared to citizens reporting issues to leaders in the comparison areas (Table 4.13). But it appears that this is driven by men, women being overall less likely to report an issue related to this topic (decrease of 8 percentage points). In addition, women are more likely to report issues related to gender-based violence to leaders as a result of the project (increase of 19 percentage points, compared to women in the comparison group). Women are also more likely to report 'other' issues than the ones listed (increase of 10 percentage points) and significantly less likely to report an issue related to education (decrease of 26 percentage points). 
Table 4.13: Topics of issues reported to leaders or officials

\begin{tabular}{|c|c|c|c|c|c|c|}
\hline & Land rights & $\begin{array}{l}\text { Gender- } \\
\text { based } \\
\text { violence }\end{array}$ & $\begin{array}{l}\text { Access to } \\
\text { water }\end{array}$ & $\begin{array}{l}\text { Access to } \\
\text { health } \\
\text { services }\end{array}$ & Education & Other \\
\hline \multicolumn{7}{|l|}{ Overall } \\
\hline $\begin{array}{l}\text { Effect of time in the comparison group } \\
\text { (Time) }\end{array}$ & $\begin{array}{c}0.0139 \\
(0.0402)\end{array}$ & $\begin{array}{c}0.0258 \\
(0.0489)\end{array}$ & $\begin{array}{l}-0.119^{* *} \\
(0.0526)\end{array}$ & $\begin{array}{l}0.00876 \\
(0.0322)\end{array}$ & $\begin{array}{c}0.0246 \\
(0.0607)\end{array}$ & $\begin{array}{l}- \\
0.00776 \\
(0.0641)\end{array}$ \\
\hline $\begin{array}{l}\text { Effect of being in the intervention group at } \\
\text { baseline (Project) }\end{array}$ & $\begin{array}{c}0.0612 \\
(0.0806)\end{array}$ & $\begin{array}{l}-0.0137 \\
(0.0568)\end{array}$ & $\begin{array}{l}-0.178^{* *} \\
(0.0832)\end{array}$ & $\begin{array}{l}-0.0640 \\
(0.0576)\end{array}$ & $\begin{array}{l}-0.0752 \\
(0.0569)\end{array}$ & $\begin{array}{l}0.198^{*} \\
(0.105)\end{array}$ \\
\hline Impact of the project (Time ${ }^{\star}$ Project) & $\begin{array}{l}0.00864 \\
(0.0707)\end{array}$ & $\begin{array}{c}0.0400 \\
(0.0646)\end{array}$ & $\begin{array}{l}0.172^{\star \star} \\
(0.0754)\end{array}$ & $\begin{array}{c}0.0351 \\
(0.0600)\end{array}$ & $\begin{array}{c}-0.119 \\
(0.0729)\end{array}$ & $\begin{array}{l}-0.0525 \\
(0.0998)\end{array}$ \\
\hline $\begin{array}{l}\text { Observations } \\
\text { Number of citizens } \\
\text { Mean at baseline in the comparison group } \\
\text { Mean at baseline in the intervention group }\end{array}$ & $\begin{array}{c}365 \\
301 \\
0.250 \\
0.294 \\
\end{array}$ & $\begin{array}{c}365 \\
301 \\
0.132 \\
0.0459 \\
\end{array}$ & $\begin{array}{l}365 \\
301 \\
0.221 \\
0.119 \\
\end{array}$ & $\begin{array}{c}365 \\
301 \\
0.0882 \\
0.101 \\
\end{array}$ & $\begin{array}{c}365 \\
301 \\
0.191 \\
0.229 \\
\end{array}$ & $\begin{array}{c}365 \\
301 \\
0.191 \\
0.294 \\
\end{array}$ \\
\hline \multicolumn{7}{|l|}{ Testing for differential impacts } \\
\hline $\begin{array}{l}\text { Effect of being a woman in the comparison } \\
\text { group at baseline (Gender) }\end{array}$ & $\begin{array}{l}-0.150 \\
(0.120)\end{array}$ & $\begin{array}{l}0.274^{* * *} \\
(0.0873)\end{array}$ & $\begin{array}{c}-0.328^{* * *} \\
(0.0902)\end{array}$ & $\begin{array}{l}-0.0634 \\
(0.0711)\end{array}$ & $\begin{array}{l}-0.101 \\
(0.0632)\end{array}$ & $\begin{array}{c}0.126 \\
(0.114)\end{array}$ \\
\hline $\begin{array}{l}\text { And in the treatment group } \\
\text { (Gender*Project) }\end{array}$ & $\begin{array}{l}0.0888 \\
(0.141)\end{array}$ & $\begin{array}{l}-0.256^{* * *} \\
(0.0975)\end{array}$ & $\begin{array}{l}0.330^{* * *} \\
(0.107)\end{array}$ & $\begin{array}{c}0.0836 \\
(0.0892)\end{array}$ & $\begin{array}{c}0.126 \\
(0.0973)\end{array}$ & $\begin{array}{l}-0.0362 \\
(0.137)\end{array}$ \\
\hline $\begin{array}{l}\text { Impact of the project among men } \\
\text { (Time*Project) }\end{array}$ & $\begin{array}{l}0.0458 \\
(0.100)\end{array}$ & $\begin{array}{l}-0.0503 \\
(0.0549)\end{array}$ & $\begin{array}{l}0.328^{* * *} \\
(0.0947)\end{array}$ & $\begin{array}{c}0.0920 \\
(0.0794)\end{array}$ & $\begin{array}{l}-0.0352 \\
(0.0955)\end{array}$ & $\begin{array}{l}-0.165^{\star} \\
(0.0878)\end{array}$ \\
\hline $\begin{array}{l}\text { Differential impacts between women and } \\
\text { men (Gender*Time }{ }^{\star} \text { Project) }\end{array}$ & $\begin{array}{r}-0.0924 \\
(0.177)\end{array}$ & $\begin{array}{l}0.240^{*} \\
(0.144)\end{array}$ & $\begin{array}{c}-0.407^{\star \star \star} \\
(0.124)\end{array}$ & $\begin{array}{l}-0.153 \\
(0.117)\end{array}$ & $\begin{array}{l}-0.223^{\star *} \\
(0.112)\end{array}$ & $\begin{array}{l}0.262^{*} \\
(0.159)\end{array}$ \\
\hline Observations & 365 & 365 & 365 & 365 & 365 & 365 \\
\hline $\begin{array}{l}\text { Number of citizens } \\
\text { Mean at baseline in the comparison group }\end{array}$ & 301 & 301 & 301 & 301 & 301 & 301 \\
\hline $\begin{array}{l}\text { Mean at baseline in the comparison group } \\
\text { among women } \\
\text { Mean at baseline in the intervention group }\end{array}$ & 0.192 & 0.308 & 0 & 0.0385 & 0.0769 & 0.269 \\
\hline among women & 0.242 & 0.0606 & 0.121 & 0.0909 & 0.242 & 0.364 \\
\hline
\end{tabular}

Robust standard errors in parentheses

${ }^{* * *} p<0.01,{ }^{* *} p<0.05,{ }^{*} p<0.1$

Difference-in-differences with random effects, village level clustered standard errors and control variables as described in Section 3.2.5 (Model 3); triple differences with random effects, village level clustered standard errors and control variables as described in Section 3.2.5 Model 5)

Note that Table 4.13 shows only the topics that were reported by at least 10 percent of citizens. Figure 4.2 shows the percentage of citizens who reported a given topic to leaders at endline in the intervention group, by gender of the respondent $(n=103)$. 
Figure 4.2: Topics discussed when reporting to the authorities

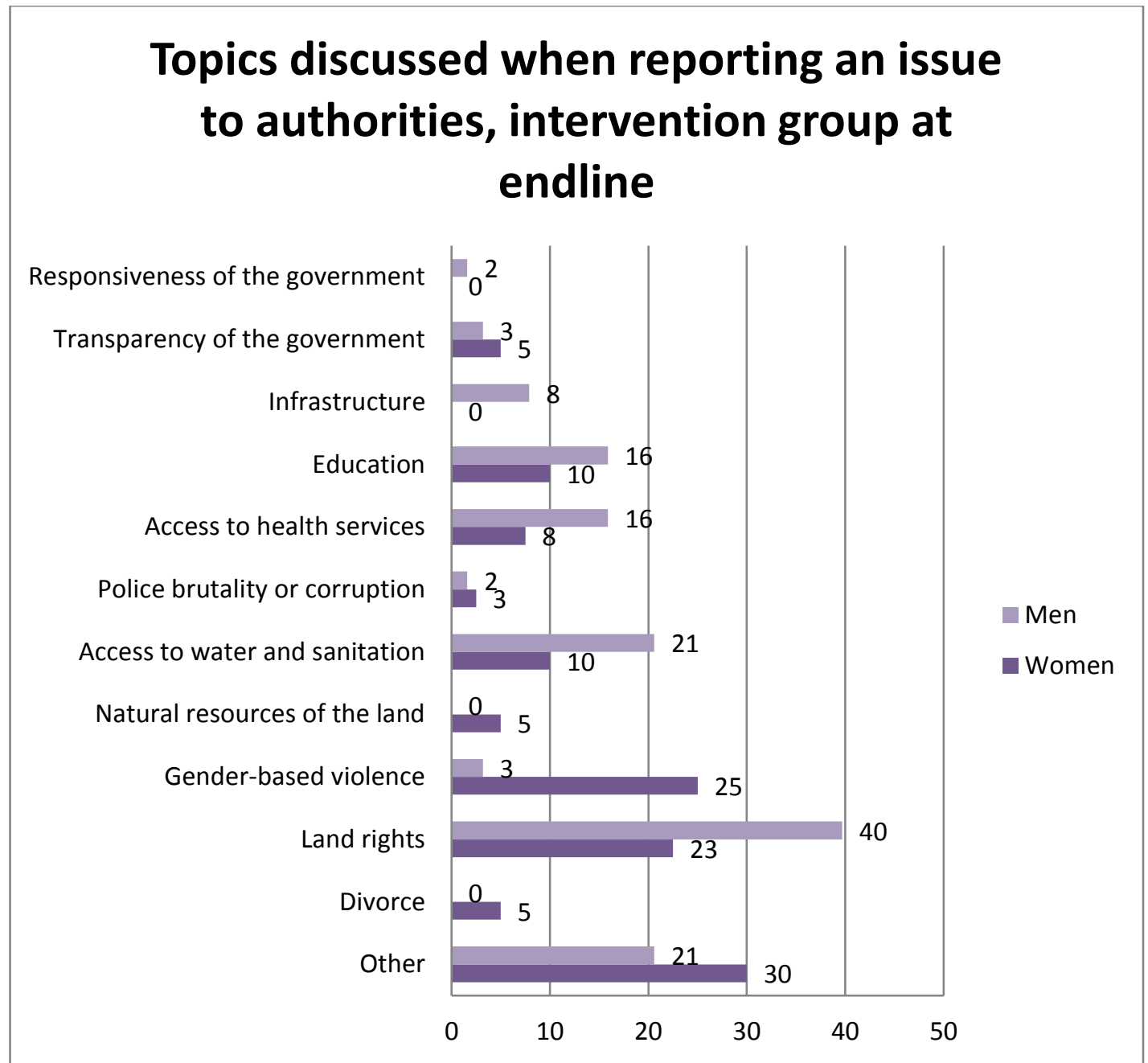

Comparing Figures 4.1 and 4.2 highlights the differences in topics discussed in public or closed spaces.

\section{Active citizenship}

Following the project definition of active citizenship (see Figure 2.2), we calculate a multidimensional index of active citizenship, made of:

- A score of knowledge of rights, to capture understanding of rights and responsibilities, rules and regulations.

- A score of participation in different civic activities, to capture involvement in community issues and leading/influencing community to take action. In particular, we take into account participation in community dialogues and village assemblies, having reported issues to leaders or journalists, having joined a protest, having spoken to other citizens about their rights, having informal conversation about rights, having mobilized others, of having fund raised.

- A score of participation in community groups, to capture interest in the well-being of the community at large.

The ICT-enabled approach is not making a significant difference on active citizenship measured through this index (Table 4.14) for women and men (although women score significantly lower than men on this index). 
Table 4.14: Active citizenship multidimensional index

\begin{tabular}{|c|c|}
\hline & $\begin{array}{l}\text { Active citizenship } \\
\text { multidimensional index }\end{array}$ \\
\hline \multicolumn{2}{|l|}{ Overall } \\
\hline Intervention mean & 0.41 \\
\hline Comparison mean & 0.42 \\
\hline Impact of the project & $\begin{array}{l}-0.01 \\
(0.02)\end{array}$ \\
\hline Observations (intervention group) & 381 \\
\hline Observations (total) & 673 \\
\hline \multicolumn{2}{|l|}{ Testing for differential impacts } \\
\hline $\begin{array}{l}\text { Effect of being a woman in the comparison } \\
\text { group }\end{array}$ & $\begin{array}{l}-0.07^{* *} \\
(0.03)\end{array}$ \\
\hline Effect of being in intervention among men & $\begin{array}{l}-0.03 \\
(0.02)\end{array}$ \\
\hline Differential impact for men and women & $\begin{array}{c}0.03 \\
(0.03)\end{array}$ \\
\hline
\end{tabular}

\subsubsection{Interaction with and perception of local government}

As shown through the Chukua Hatua experience (Green, 2015), and through the qualitative case studies, the animation approach requires to build the relationship between animators and local leaders, which takes time and may come with tensions (see Section 4.2.5). In this context, we observe an increase in the share of animators being invited to participate in meetings with local government authorities in the last 12 months, as a result of the project, compared to animators in villages relying mainly on the traditional approach. Indeed, Table 4.15 shows that the project enabled an increase of 26 percentage points in the share of animators having been invited by hamlet or village leaders (significant at 10 percent), and an increase of 36 percentage points in the share of animators having been invited by ward or district leaders. ${ }^{25}$ 
Invited to participate in meetings with hamlet or village leaders
Invited to participate in meetings with ward or district leaders
Effect of time in the comparison group (Time)

Effect of being in the intervention group at baseline (Project)

Impact of the project (Time* Project)
$-0.0112$

0.0586

$0.258^{*}$
0.0735

(0.0812)

0.166

$(0.116)$

$0.358^{\star *}$

$(0.140)$

Observations 119 114

Number of animators

Mean at baseline in the comparison group

Mean at baseline in the intervention group 0.697

Robust standard errors in parentheses

${ }^{* * *} p<0.01,{ }^{* *} p<0.05,{ }^{*} p<0.1$

Difference-in-differences with village level clustered standard errors (Model 1)

Overall, significantly more animators in the intervention group judge that their relationship with hamlet and village leaders or officials has improved as a result of being an animator.

(Table not shown; available upon request.) The qualitative case studies indeed highlight that the animator-leader relationship is fraught with frictions and tensions, and that this improved during the course of the project (see Section 4.2).

Consistent with the results presented in the previous section is the extent to which citizens engage with officials through lobby meetings, community dialogues or through reporting an issue has not been affected by the project (negative and non-significant effect). There was no differential impact between women and men; however, women were more likely not to engage than men in the first place (-27 percentage points compared to men, in the comparison group). Among citizens who reported an issue to leaders, they were more likely in the intervention group to report that the issue was not addressed (a 17 percentage points decrease, while 74 percent considered the issue addressed at baseline in the intervention group). 


\begin{tabular}{|c|c|c|}
\hline & \multirow[b]{2}{*}{$\begin{array}{l}\text { Participated in lobby } \\
\text { meeting community } \\
\text { dialogue or has reported } \\
\text { an issue to local leaders }\end{array}$} & \multirow{2}{*}{$\begin{array}{l}\text { Among those who } \\
\text { reported an issue } \\
\text { The issue reported to } \\
\text { leaders was addressed }\end{array}$} \\
\hline & & \\
\hline Effect of time in the comparison group (Time) & $\begin{array}{l}0.126^{* * *} \\
(0.0385)\end{array}$ & $\begin{array}{c}0.0982 \\
(0.0647)\end{array}$ \\
\hline $\begin{array}{l}\text { Effect of being in the intervention group at } \\
\text { baseline (Project) }\end{array}$ & $\begin{array}{c}0.0359 \\
(0.0458)\end{array}$ & $\begin{array}{l}0.173^{* *} \\
(0.0693)\end{array}$ \\
\hline Impact of the project (Time ${ }^{\star}$ Project) & $\begin{array}{l}-0.0315 \\
(0.0495)\end{array}$ & $\begin{array}{l}-0.166^{\star *} \\
(0.0805)\end{array}$ \\
\hline Observations & 1,404 & 366 \\
\hline Number of citizens & 702 & 302 \\
\hline Mean at baseline in the comparison group & 0.395 & 0.618 \\
\hline Mean at baseline in the intervention group & 0.484 & 0.743 \\
\hline
\end{tabular}

Robust standard errors in parentheses

*** $p<0.01,{ }^{* *} p<0.05,{ }^{*} p<0.1$

Difference-in-differences with random effects, village level clustered standard errors and control

variables as described in Section 3.2.5 (Model 3)

However, citizens are more likely to report that the village meetings are happening at least every three months as a result of the project, which shows an impact of the project on this aspect of local governance, compared to villages with a traditional animation approach (Table 4.17). At baseline, 84 percent of citizens identified that village meetings were taking place every three months or more often, and the project has enabled a 16 percentage point increase (by law, village meetings have to take place at least every three months).

Table 4.17: Frequency of village meetings instituted by law

\begin{tabular}{lc}
\hline & $\begin{array}{c}\text { Village meetings took place } \\
\text { every 3 months or more often }\end{array}$ \\
\hline Effect of time in the comparison group (Time) & $-0.173^{\star *}$ \\
Effect of being in the intervention group at baseline (Project) & $(0.0706)$ \\
& -0.0164 \\
Impact of the project (Time*Project) & $(0.0557)$ \\
& $0.160^{\star *}$ \\
Observations & $(0.0763)$ \\
Number of ciitizens & 1,404 \\
Mean at baseline in the comparison group & 702 \\
Mean at baseline in the intervention group & 0.834 \\
\hline
\end{tabular}

Robust standard errors in parentheses

${ }^{* * *} p<0.01,{ }^{* *} p<0.05,{ }^{*} p<0.1$

Difference-in-differences with random effects, village level clustered standard errors and control

variables as described in Section 3.2.5 (Model 3)

This did not translate into more transparency or availability at the village level (Table 4.18): 63 percent of citizens declared that village leaders have presented income and expenses of the village since September 2017, and 77 percent that the village executive officer has been more available for citizens since September 2017, and this was very similar in the comparison group. 
are estimated through PS weighted regressions with clustered standard errors at the village level (Model 6).

At district level, 17 percent of citizens declared that district leaders have presented income and expenses since September 2017 (against 5 percent of citizens in the comparison group). More citizens also considered that district officers' availability has improved as a result of the project (46 percent, against 28 percent in the comparison group) (Table 4.20).

Table 4.20: transparency and availability of district leaders and officials

\begin{tabular}{lcc} 
& $\begin{array}{c}\text { District leaders have } \\
\text { presented income } \\
\text { and expenses since } \\
\text { September 2017 } \\
(\%)\end{array}$ & $\begin{array}{c}\text { District officers have } \\
\text { been more available } \\
\text { for citizens since } \\
\text { September 2017 } \\
(\%)\end{array}$ \\
\hline Overall & 17.24 & 46.03 \\
\hline Intervention mean & 5.30 & 28.47 \\
Comparison mean & $11.6^{* * *}$ & $17.2^{* *}$ \\
Impact of the project & $(4.4)$ & $(7.2)$ \\
Observations (intervention group) & 174 & 252 \\
Observations (total) & 321 & 439 \\
\hline Testing for differential impacts & & 3.6 \\
\hline Effect of being a woman in the comparison & $10.5^{* *}$ & $(10.3)$ \\
group & $(5.0)$ & $15.9^{*}$ \\
Effect of being in intervention among men & $15.7^{* * *}$ & $(9.5)$ \\
Differential impact for men and women & $(3.4)$ & 6.7 \\
\hline
\end{tabular}

Standard errors in parentheses; ${ }^{*} p<0.1,{ }^{\star *} p<0.05,{ }^{* * *} p<0.01$; PSM estimates are bootstrapped with 1,000 repetitions, standard errors are clustered at the village level (Model 4). Differential impacts are estimated through PS weighted regressions with clustered standard errors at the village level (Model 6).

The survey included questions on responsiveness of leaders or officials (village, ward and district levels) and the project did not impact the perception of citizens of their responsiveness. According to citizens, the project did not impact the ease in accessing relevant information from different authorities either. (Table not shown; available upon request.) Note that trust in governmental institutions among women and men citizens was not affected by the project. (Table not shown; available upon request.)

\subsubsection{Mobilization and bottom-up reform agenda}

\section{Stories of mobilization (animators and citizens)}

To understand further the mobilizations and activism ongoing in the setting of the project, animators and citizens were asked to share a story at the beginning of the interview (building on the SenseMaker ${ }^{26}$ approach). The interviewer asked: 'Think about your life and that of other village members since September 2017. I would like you to share a story about any type of mobilization that has taken place in your village since September 2017. Could you please elaborate on what happened, who was involved and what was the outcome?' The follow-up questions were related to the story shared. The respondent was asked to give a title to the story they shared, and to interpret their own story based on these questions.

Animators involved in the project are significantly more likely to share a story of mobilization, as shown in Table 4.21 (an increase of 13 percentage points, while 84 percent of animators Governance and Accountability through Digitalization in Tanzania 
shared a story in the comparison group). Among those who shared a story, animators in both groups are as likely to be personally involved in the mobilization they describe (and this is the case in most of stories shared - 86 percent in the comparison group). The stories shared in the intervention group are much more likely to involve the use of social media (increase of 42 percentage points. Only 14 percent of animators in the comparison group shared a story that involved social media) to improve the outcome of the story, and when social media is used for it to be considered instrumental.

Table 4.21: Stories of mobilization shared by animators

\begin{tabular}{|c|c|c|c|c|c|}
\hline & \multirow[b]{2}{*}{$\begin{array}{l}\text { Shared a } \\
\text { story of } \\
\text { mobilization }\end{array}$} & \multicolumn{4}{|c|}{ Among those who shared a story } \\
\hline & & $\begin{array}{l}\text { Animator } \\
\text { personally } \\
\text { involved in } \\
\text { the } \\
\text { mobilization }\end{array}$ & $\begin{array}{l}\text { Use of } \\
\text { social } \\
\text { media } \\
\text { involved } \\
\text { in the } \\
\text { story }\end{array}$ & $\begin{array}{c}\text { Outcome } \\
\text { of the } \\
\text { story - } 0 \\
\text { negative, } \\
10 \\
\text { positive }\end{array}$ & $\begin{array}{c}\text { Importance } \\
\text { of the use } \\
\text { of social } \\
\text { media - } 0 \\
\text { not at all, } \\
10 \text { very }{ }^{27}\end{array}$ \\
\hline Impact of the project (Project) & $\begin{array}{l}0.131^{\star *} \\
(0.0565)\end{array}$ & $\begin{array}{l}0.0175 \\
(0.132)\end{array}$ & $\begin{array}{c}0.419^{* * *} \\
(0.139)\end{array}$ & $\begin{array}{c}2.362^{\star * *} \\
(0.658)\end{array}$ & $\begin{array}{l}2.528^{\star} \\
(1.412)\end{array}$ \\
\hline Observations & 62 & 56 & 56 & 56 & 26 \\
\hline $\begin{array}{l}\text { R-squared } \\
\text { Mean at endline in the comparison }\end{array}$ & 0.178 & 0.044 & 0.406 & 0.160 & 0.177 \\
\hline group & 0.840 & 0.857 & 0.143 & 3.429 & 4.667 \\
\hline
\end{tabular}

Robust standard errors in parentheses

${ }^{* * *} p<0.01,{ }^{* *} p<0.05,{ }^{*} p<0.1$

Multivariate regression with baseline control variables (Model 2)

In the comparison group, only three animators shared a story that involved social media. Looking at these stories in more detail allows exploring whether the mechanisms behind the use of social media, although rare, are different in the comparison group. ${ }^{28}$

The first story is called 'About pasture':

'Conservation stopped people tending their cattle along the crater; before this order this area was used to tending and feeding their cattle because that is the only area they could get grass during the dry season. The villagers were mobilized because they are all breeders, so as animator, I talked to them in order to mobilize them. After grazing was stopped during the dry season, many cows died because they could not be fed nor be given water. And also the amount of milk decreased during the dry season and sometimes they don't get milk at all. I posted on social media and they sent traditional leaders to go and meet the chief conservator. I also tagged the minister who is responsible. All villagers joined together on this issue because they all own cows. The people who opposed the mobilization are people who work in conservation, although they are Maasai.' (Story shared by a man animator in Arusha, above 35 years old.)

While the first story shows direct use of social media, the two other stories are less clear on the way social media was involved.

The second story is called 'Unavailability of village office':

'The problem was that we did not have a village office; I mobilized the villagers to contribute some amount so as to solve the problem. Hence the contributions were made and the support from the government was given to the citizens.' (Story shared by a man animator in Arusha, below 35 years old.) 
The third story is called 'Accident':

'An accident involving a motorcyclist who hit a police car resulted in the motorcyclist breaking his hand. We mobilized to take him to the hospital. No one died. The incident happened near the police station.' (Story shared by a woman animator in Geita, below 35 years old.)

In the first story shared by a former Chukua Hatua animator in the comparison group, the mechanism behind the use of social media is similar to the project logic, and similar to the stories in which social media is involved shared by the project animators - although more frequent in that group. ${ }^{29}$ For example, one animator tells a story called 'Government mobilization on cotton cultivation':

'Villagers planted cotton and did not have pesticides for their cotton. The animator mobilized the farmers by calling a meeting and agreeing to take pictures of their destroyed cotton and post it on social media. The farmers were happy as three days after the pictures were posted online, the government sent the pesticides to them.' (Story shared by a man animator in Geita, above 35 years old.)

Another one is called 'Boundaries conflict':

'There was a conflict of boundaries between two villages. The animators played a key role in mobilization around the conflict, which was caused by the gas reserve on the boundary of the village. Animators reported the matter at a district level and the case ended by everyone being shown their boundaries.' (Story shared by a woman animator in Mtwara, below 35 years old.)

Another one is called 'Land conflict':

'There was a conflict between the villagers and the village government. It happened after the government invaded the village's land without giving the owners information. This event led villagers to riot and some of the villagers to report the problem to the higher government authorities. The village government prohibited those who went to report the problem from attending village meetings. Later the district director called for a meeting to stop the behaviour of the village leaders, but village leaders did not adhere to the district director's orders and proceeded with using the land, cutting and burning trees. The villagers reported to the authorities again, but nothing has been done so far.' (Story shared by a man animator in Arusha, above 35 years old.)

Another one is called 'Let us have a good response in education for the coming generation': 'Animators were not happy with the situation at school with students having to sit on the floor. They called for a meeting and explained the problem. It was also reported at the village leaders meeting; animators and citizens discussed how to solve such problems by using available resources, such as trees, to create the desks.' (Story shared by a woman animator in Kigoma, below 35 years old.)

On this matter, the qualitative case studies report (Towo et al., 2019) describes four cases of such mobilization and their outcomes in detail, presenting the village context and history of mobilization. These are related to school facilities, school staff and land use by a company in two villages in Arusha and one village in Kigoma. In the Nduta refugee camp, the qualitative case study describes mobilization supported by the use of smartphones related to water and sanitation infrastructure maintenance, domestic physical violence and sexual violence against women.

Among those who shared a story of mobilization, the project animators were significantly less likely to share a story related to access to social services, and more likely to share a story related to other topics (respect of the rights of Tanzanian citizens, transparency of local government, responsiveness of local government and others) than those in the comparison group. (Table not shown; available upon request.) As mobilization around discrimination and violence against women and girls emerged as a theme from the case studies and from the reading of all the stories shared by animators, we reclassified the stories based on whether they are related to discrimination or violence against women and girls. Animators in the 
intervention group are significantly more likely to share a story on this topic than in the comparison group (increase of 21 percentage points, with one story out of 21 being about it in the comparison group. Table not shown; available upon request). The stories are not easy to read, but are available upon request. The titles of the stories in the intervention group are as follows: 'Gender discrimination', 'Gender discrimination and cruelty', 'Raping', 'Shocking event', 'Invasion in the farms', 'Two old women raped by a young man', 'Gender cruelty event', 'Unfair treatment'.

The same approach was followed with the citizens, and only 55 percent of citizens had a story to share in the intervention group, and that was not impacted by the project (Table 4.22). This speaks to previous results on citizens' engagement. Among those who shared a story, 67 percent of respondents were personally involved in the described mobilization. This is not statistically different in both groups. A very small share of citizens identified the use of social media as being part of the story they shared ( 6 percent in the intervention group, not impacted by the project). The results are not different for women and men.

Table 4.22: Stories of mobilization shared by citizens

\begin{tabular}{|c|c|c|c|c|}
\hline & \multirow[b]{2}{*}{$\begin{array}{c}\text { Shared a story of } \\
\text { mobilization } \\
(\%)\end{array}$} & \multicolumn{3}{|c|}{ Among citizens who shared a story } \\
\hline & & $\begin{array}{l}\text { Respondent } \\
\text { personally } \\
\text { involved in the } \\
\text { mobilization } \\
(\%)\end{array}$ & $\begin{array}{c}\text { Use of social } \\
\text { media involved } \\
\text { in the story } \\
(\%)\end{array}$ & $\begin{array}{c}\text { Outcome of the } \\
\text { story }-0 \\
\text { negative, } 10 \\
\text { positive }\end{array}$ \\
\hline \multicolumn{5}{|l|}{ Overall } \\
\hline Intervention mean & 55.38 & 66.82 & 6.16 & 4.35 \\
\hline Comparison mean & 58.68 & 75.00 & 4.70 & 3.91 \\
\hline $\begin{array}{l}\text { Impact of the project } \\
\text { Observations }\end{array}$ & $\begin{array}{l}-3.3 \\
(8.6)\end{array}$ & $\begin{array}{l}-6.7 \\
(6.5)\end{array}$ & $\begin{array}{c}1.2 \\
(2.6)\end{array}$ & $\begin{array}{l}0.51 \\
(0.41)\end{array}$ \\
\hline (intervention group) & 381 & 211 & 211 & 211 \\
\hline Observations (total) & 673 & 390 & 390 & 390 \\
\hline \multicolumn{5}{|l|}{$\begin{array}{l}\text { Testing for differential } \\
\text { impacts }\end{array}$} \\
\hline $\begin{array}{l}\text { Effect of being a woman } \\
\text { in the comparison group }\end{array}$ & $\begin{array}{c}8.5 \\
(5.7)\end{array}$ & $\begin{array}{c}3.1 \\
(10.1)\end{array}$ & $\begin{array}{l}7.4^{* *} \\
(3.2)\end{array}$ & $\begin{array}{l}0.97^{\star *} \\
(0.42)\end{array}$ \\
\hline $\begin{array}{l}\text { Effect of being in } \\
\text { intervention among men }\end{array}$ & $\begin{array}{l}-3.5 \\
(7.9)\end{array}$ & $\begin{array}{l}-3.7 \\
(8.5)\end{array}$ & $\begin{array}{l}4.5^{*} \\
(2.5)\end{array}$ & $\begin{array}{l}0.88^{*} \\
(0.52)\end{array}$ \\
\hline $\begin{array}{l}\text { Differential impact for } \\
\text { men and women }\end{array}$ & $\begin{array}{c}0.7 \\
(6.6)\end{array}$ & $\begin{array}{l}-10.4 \\
(13.3)\end{array}$ & $\begin{array}{l}-5.6 \\
(4.7) \\
\end{array}$ & $\begin{array}{l}-0.89 \\
(0.63)\end{array}$ \\
\hline
\end{tabular}

Standard errors in parentheses; ${ }^{*} p<0.1,{ }^{* *} p<0.05,{ }^{* * *} p<0.01$; PSM estimates are bootstrapped with 1,000 repetitions, standard errors are clustered at the village level (Model 4). Differential impacts are estimated through PS weighted regressions with clustered standard errors at the village level (Model 6).

Comparing the results between citizens and animators, animators appear to be more positive than citizens about the outcome of the stories they shared as being a result of the project.

\section{Human rights violation}

The project did not impact awareness of prevalence of domestic violence and ability to divorce, or support of hamlet leaders to the survivor, as shown in Table 4.23. Note that 18 percent of citizens in the intervention group are aware of situation where a woman in the village could not divorce her husband, in spite of him treating her cruelly, and 9 percent of the hamlet leaders not issuing a letter attesting of domestic violence, after a woman reported the abuse. Awareness seem to have changed on two topics, however. First, as a result of the project, women citizens are significantly more likely to acknowledge that a man from the 
village inherited from his parents, while his sister did not, (+13 percentage points among women respondents). Second, men and women citizens are more likely to acknowledge that a girl under 18 got married in the village: 25 percent of citizens do so in the comparison group, against 38 percent in the intervention group.

Table 4.23: citizens' awareness of instances of women and girls' right violation in their village

A woman in your village reported to the hamlet leader having been

A woman in your village could not divorce her husband, in spite of him treating her cruelly

(\%) beaten by her husband. The hamlet leader did not issue a letter attesting of the situation.

\section{A man from your village inherited from his parents, while his sister did not. \\ In your village, a girl under 18 got married.} (\%)

21.26

37.80

25.01

8.17

15.13

$12.8^{* *}$

\section{1}

1.0

(2.8)

6.1

Impact of the project

381

381

(intervention group)

673

381

673

$\begin{array}{cc}0.4 & 4.5 \\ (2.3) & (3.7) \\ -0.4 & -0.2 \\ (1.6) & (3.2) \\ 3.0 & 13.6^{* *} \\ (3.7) & (5.9)\end{array}$

\section{Testing for differential} impacts

Effect of being a woman
in the comparison group
Effect of being in
intervention among men
Differential impact for
men and women

$\begin{array}{cc}9.9^{\star *} & 0.4 \\ (4.8) & (2.3) \\ 0.8 & -0.4 \\ (4.0) & (1.6) \\ 3.5 & 3.0 \\ (6.8) & (3.7)\end{array}$

3.4

Standard errors in parentheses; * $p<0.1,{ }^{* *} p<0.05,{ }^{* * *} p<0.01$; PSM estimates are bootstrapped with 1,000 repetitions, standard errors are clustered at the village level (Model 4). Differential impacts are estimated through PS weighted regressions with clustered standard errors at the village level (Model 6).

Note that the survey did not include questions on awareness or prevalence of female genital mutilation, but two of the cases studied by the qualitative team identify it as a major human rights violation ongoing in the villages in Arusha (see Towo et al., 2019). Animators of one of the two villages studied are mobilizing on the matter. The quantitative data show that only 42 percent of citizens identify that female genital mutilation is not legal, and 40 percent that someone performing female genital mutilation on someone under 18 is committing an offence of cruelty to children (see Appendix 2 for the questions included on knowledge of rights in the survey). ${ }^{30}$

The project did not impact prevalence, or awareness of prevalence, on land rights violation, as shown in Table 4.24. In the intervention group, 11 percent of citizens are aware of the government not involving village members before using a part of their land; 6 percent of citizens are aware of a company extracting natural resources from a land in the village or nearby not paying a share of its annual sales to the local government authorities. 
Table 4.24: Citizens' awareness of instances of land rights violation in their village

\begin{tabular}{lcc}
\hline & $\begin{array}{c}\text { The government did } \\
\text { not involve the } \\
\text { village members } \\
\text { before using a part of } \\
\text { the land that they } \\
\text { possess } \\
(\%)\end{array}$ & $\begin{array}{c}\text { A company extracting } \\
\text { natural resources from a } \\
\text { land in the village or } \\
\text { nearby is not paying a } \\
\text { share of its annual sales } \\
\text { to the local government } \\
\text { authorities } \\
(\%)\end{array}$ \\
\hline Overall & & \\
\hline Intervention mean & 11.02 & 5.77 \\
Comparison mean & 10.24 & 5.97 \\
& 0.8 & -0.2 \\
Impact of the project & $(2.4)$ & $(3.3)$ \\
Observations (intervention group) & 381 & 381 \\
Observations (total) & 673 & 673 \\
\hline Testing for differential impacts & & -10.0 \\
\hline Effect of being a woman in the comparison & $6.2^{*}$ & $(6.7)$ \\
group & $(3.3)$ & -4.3 \\
& -1.4 & $(5.7)$ \\
Effect of being in intervention among men & $(2.9)$ & 8.5 \\
& 4.9 & $(7.4)$ \\
\hline Differential impact for men and women & $(3.9)$ & \\
Standard errors in parentheses; ${ }^{*} p<0.1,{ }^{* *} p<0.05,{ }^{* * *} p<0.01 ;$ PSM estimates are bootstrapped \\
with 1,000 repetitions, standard errors are clustered at the village level (Model 4). Differential impacts \\
are estimated through PS weighted regressions with clustered standard errors at the village level \\
(Model 6). & & \\
\end{tabular}

However, Table 4.25 shows some small but significant effect on compensation and service levy. Almost 4 percent of households have received compensation from a company using their land in the past 12 months in the intervention group, against less than 1 percent in the comparison group. 10 percent of citizens identify that the district government has received the service levy from company exploiting natural resources from their land, against only 5 percent in the comparison group (difference significant at 10 percent). This effect seems to be driven by women respondents in the intervention group. This suggests that the project may have improved information on the matter, rather than actual change at district level. 


\begin{tabular}{|c|c|c|c|}
\hline & $\begin{array}{c}\text { The household } \\
\text { received } \\
\text { compensation } \\
\text { from a company } \\
\text { using their land } \\
\text { in the past } 12 \\
\text { months } \\
(\%)\end{array}$ & $\begin{array}{l}\text { The government } \\
\text { has received } \\
\text { compensation in } \\
\text { the last } 12 \\
\text { months from a } \\
\text { company } \\
\text { using collective } \\
\text { land } \\
(\%)\end{array}$ & $\begin{array}{l}\text { The district } \\
\text { government has } \\
\text { received the } \\
\text { service levy from } \\
\text { company } \\
\text { exploiting natural } \\
\text { resources from } \\
\text { the land in the } \\
\text { last } 12 \text { months } \\
(\%)\end{array}$ \\
\hline \multicolumn{4}{|l|}{ Overall } \\
\hline Intervention mean & 3.67 & 7.35 & 10.24 \\
\hline Comparison mean & 0.66 & 5.86 & 5.18 \\
\hline Impact of the project & $\begin{array}{l}3.0^{* *} \\
(1.4)\end{array}$ & $\begin{array}{l}1.5 \\
(3.1)\end{array}$ & $\begin{array}{l}5.1^{*} \\
(3.0)\end{array}$ \\
\hline Observations (intervention group) & 381 & 381 & 381 \\
\hline Observations (total) & 673 & 673 & 673 \\
\hline \multicolumn{4}{|l|}{ Testing for differential impacts } \\
\hline $\begin{array}{l}\text { Effect of being a woman in the } \\
\text { comparison group }\end{array}$ & $\begin{array}{l}-2.1 \\
(2.0)\end{array}$ & $\begin{array}{l}-5.4^{*} \\
(3.2)\end{array}$ & $\begin{array}{l}-6.4^{\star *} \\
(2.7)\end{array}$ \\
\hline $\begin{array}{l}\text { Effect of being in intervention } \\
\text { among men }\end{array}$ & $\begin{array}{l}2.4 \\
(1.8)\end{array}$ & $\begin{array}{l}-2.0 \\
(3.6)\end{array}$ & $\begin{array}{c}1.5 \\
(3.6)\end{array}$ \\
\hline $\begin{array}{l}\text { Differential impact for men and } \\
\text { women }\end{array}$ & $\begin{array}{c}1.1 \\
(2.3)\end{array}$ & $\begin{array}{r}6.7^{*} \\
(3.6) \\
\end{array}$ & $\begin{array}{l}6.8^{*} \\
(3.5) \\
\end{array}$ \\
\hline
\end{tabular}

\section{Social services}

The survey explored changes in social services in the village since September 2017, through questions about actual new building, renovation or improvement on:

- Education facilities (pre-primary, primary, secondary and high school)

- Health facilities (dispensary, health centre and hospital)

- Electricity (home connection to the grid)

- Water infrastructure (home connection to an improved source)

- Road into the village

- Public toilet and other facilities.

The survey also included questions on future plan to build or improve education and health facilities, and electricity infrastructure. Using this information, we calculate four different scores and the impact results are presented in Table 4.26. First, it appears that building, renovation or improvement has taken place in significantly more areas in the intervention villages than in the comparison ones: in the comparison group, changes have been observed by citizens in two of the six above-mentioned areas, while this is closer to three in the intervention group. Second, the total number of improvements is also going up, but not significantly for the whole sample (only according to men respondents at 10 percent, and to animators. Table not shown; available upon request). There seem to be more plans for building or improvement agreed by the government that citizens are aware of: from 0.3 to 0.7 on average (difference significant at 10 percent). Note that 50 percent of citizens in the intervention group identify that the government agreed on any such plan in the future (and that is not statistically different from the comparison group). 
Table 4.26: Building, renovation or improvement and future plans

\begin{tabular}{|c|c|c|c|c|}
\hline & $\begin{array}{c}\text { Building, } \\
\text { renovation or } \\
\text { improvement } \\
\text { in } 6 \text { areas of } \\
\text { social } \\
\text { services - } \\
\text { Number of } \\
\text { areas }\end{array}$ & $\begin{array}{l}\text { Total number } \\
\text { of building, } \\
\text { renovations } \\
\text { or } \\
\text { improvements }\end{array}$ & $\begin{array}{c}\text { Plan of } \\
\text { building or } \\
\text { improvement } \\
\text { in } 3 \text { areas of } \\
\text { social } \\
\text { services - } \\
\text { Number of } \\
\text { areas }\end{array}$ & $\begin{array}{l}\text { Any plan of } \\
\text { building or } \\
\text { improvement } \\
\text { in } 3 \text { areas of } \\
\text { social } \\
\text { services } \\
(\%)\end{array}$ \\
\hline \multicolumn{5}{|l|}{ Overall } \\
\hline Intervention mean & 2.62 & 3.26 & 0.67 & 47.24 \\
\hline Comparison mean & 2.05 & 2.77 & 0.33 & 31.44 \\
\hline Impact of the project & $\begin{array}{l}0.57^{\star *} \\
(0.28)\end{array}$ & $\begin{array}{l}0.49 \\
(0.39)\end{array}$ & $\begin{array}{l}0.34^{*} \\
(0.19)\end{array}$ & $\begin{array}{c}15.8 \\
(13.0)\end{array}$ \\
\hline Observations (intervention group) & 381 & 381 & 381 & 381 \\
\hline Observations (total) & 673 & 673 & 673 & 673 \\
\hline \multicolumn{5}{|l|}{ Testing for differential impacts } \\
\hline $\begin{array}{l}\text { Effect of being a woman in the } \\
\text { comparison group }\end{array}$ & $\begin{array}{l}-0.04 \\
(0.13)\end{array}$ & $\begin{array}{l}-0.14 \\
(0.18)\end{array}$ & $\begin{array}{l}-0.05 \\
(0.07)\end{array}$ & $\begin{array}{l}-8.4 \\
(6.2)\end{array}$ \\
\hline $\begin{array}{l}\text { Effect of being in intervention among } \\
\text { men }\end{array}$ & $\begin{array}{l}0.57^{\star *} \\
(0.28)\end{array}$ & $\begin{array}{l}0.56^{*} \\
(0.34)\end{array}$ & $\begin{array}{l}0.38^{*} \\
(0.21)\end{array}$ & $\begin{array}{l}17.0 \\
(13.9)\end{array}$ \\
\hline $\begin{array}{l}\text { Differential impact for men and } \\
\text { women }\end{array}$ & $\begin{array}{l}-0.01 \\
(0.21)\end{array}$ & $\begin{array}{l}-0.14 \\
(0.35)\end{array}$ & $\begin{array}{l}-0.11 \\
(0.12)\end{array}$ & $\begin{array}{l}-3.7 \\
(9.3)\end{array}$ \\
\hline
\end{tabular}

Standard errors in parentheses; ${ }^{*} p<0.1,{ }^{* *} p<0.05,{ }^{* * *} p<0.01$; PSM estimates are bootstrapped with 1,000 repetitions, standard errors are clustered at the village level (Model 4). Differential impacts are estimated through PS weighted regressions with clustered standard errors at the village level (Model 6).

\subsection{QUALITATIVE CASE STUDIES}

\section{Authors: Esther Towo, Benson Ndiege, Ezra Wango and Mwanahawa Mhina}

The qualitative case studies were carried out in four villages: two in Arusha, and in one village and refugee camp in Kigoma. A discussion of the main observations is presented here, drawing from four cases in which mobilization and outcome were observed. The four cases are not representative of the whole project as the cases were purposefully selected from among those with a high level of mobilization and visible changes in human rights promotion. Because the case studies focused on the relationship between animators, citizens and leaders, the cases were selected among villages which had improved relationships between local government duty bearers (district, ward and village), animators and citizens by the course of the project (see Section 3.3). Each case is presented in detail in the case study report.

\subsubsection{Voice}

Online platforms promoted individual and collective action in engaging citizens to address their problems. Animators got information from citizens related to their problems and shared them through tweets, messages on WhatsApp, and Facebook groups. Through these online platforms, the voice of the citizens reached higher government authorities. For example, a village leader remarked: 'There was a land conflict between village $B$ and a neighbouring village last year, the animator took photos of what was happening between the village chairperson and the police. He forwarded the photos to the district leaders, and we just saw the district leaders arriving within a short time and immediate action was taken.' This helped the citizens to get responses to some of their challenges in a short time. In some cases, the duty bearers communicated directly with animators on the challenges tweeted. For example, Governance and Accountability through Digitalization in Tanzania 
in village A an animator said; 'Last year there was a cholera outbreak in the village, I tweeted the matter. Then the Regional Commissioner contacted us.' Animators were highly motivated to search for information and communicated successfully to the higher authorities, like permanent secretaries and ministers. For example, in village $C$, an animator said 'We were happy to see deputy minister coming in our village to solve the sand mining conflict which we posted on Twitter.'

The extent and type of online activities that animators engaged with (Twitter vs WhatsApp groups in particular) varied from one location to another. Probably these were due to the sensitivity of the issues reported, and the proper identification of duty bearers and social media influencers to address the identified issues. In all cases studied, online platforms were used in parallel with offline platforms in raising the voice of citizens. The offline platforms comprised informal and formal meetings. The use of offline platforms helped animators to receive and disseminate information to and from citizens.

Moreover, live streaming and radio programmes were two different mechanisms that supplemented the use of online platforms through smartphones and offline activities in enhancing citizens' voice. The radio programmes facilitated debate between citizens and duty bearers. The radio programmes were useful in raising awareness on various issues related to human rights and social services. According to one of the interviewed project partners: 'The citizens used community radio to call out leaders to respond to various issues they raised.' With regard to Twitter and YouTube live streaming sessions, social media influencers played a key role. They facilitated animators with limited followers to reach and capture the attention of the public (see Section 4.2.4 for more on this).

\subsubsection{Dialogue}

Citizens' engagement in dialogue was facilitated by both online and offline platforms. Participation in formal village meetings improved over a period of time in all four cases. This was due to behavioural change, transparency of leaders, and increased awareness of citizens. A village leader said: 'The number of citizens attending meetings has increased from an average of 100 to 500.' The reason was that citizens preferred the manner in which meetings were conducted. An elderly male in village B said, 'The village leaders present all the matters related to the village in the village assembly.' The important issues presented included income and expenditure reports, which were read and elaborated in meetings. An elderly man said, 'Village leader present income and expenditure report.' A noticeable improvement in the meetings was women and youth participation. An elderly woman in village B said, 'Previous years, women were not participating in any village or traditional meeting. Since last year, there is a tremendous change. Women sit together with men and contribute their views in the meetings.' Women's recognition of their right to express their views has increased. An elderly man in village B said, 'Now women do participate in the meetings convened by the village government and give their opinions.' However, their participation in traditional meetings is still limited, as observed by an elderly man in the same village: 'Women do participate in meetings, but when traditional instruments occur, such as age set groups meetings, women are not involved because they do not belong to any age set groups.' Important to highlight that the quantitative results show that such improvement in village meeting attendance, and of women's attendance in particular, is not observed at scale (see Section 4.1.3). The four cases were studied because of mobilization and outcome having taken place in these areas, and behavioural changes that enabled higher village meetings participation appeared as a key factor.

On the other hand, the number of meetings convened and the participation of citizens increased. At scale, village meetings indeed appear to take place more regularly as a result of the project (see Section 4.1.4). In the four cases studied, this increase in the number of meetings and participation was influenced by the animators, who not only raised awareness to citizens, but also consulted leaders to convene such meetings. In some cases, traditional meetings were strengthened with respect to participation and contribution to development issues. The space for informal meetings increased with time. Discussion on development 
issues and human rights emerged in informal gatherings. It was in these informal meetings that different queries and issues were brought to light by the citizens. For instance, a youth in village A said, 'In our age set meetings we generate ideas and discuss contributions to development initiatives in the village.

Similarly, a youth in village B said, 'We discussed in our age set group the idea of not putting on the traditional sword "Sime". Then we consulted the elders, the elders agreed and then it was forwarded to the village government. The village government accepted the idea and came up with by-laws to guide that decision.'

Consultation between leaders and citizens increased as the relationship improved. A leader in village B said that 'the animators came and explained that they are here to promote, influence and advocate for community rights, we understood them and accepted them'. He added that 'they are too close to the citizens'. An animator in village B said, 'Currently, our relationship with village leaders is good as we consult them in everything we do. They work together with us and they understand us because they know and appreciate what we are doing as far as development activities of the village are concerned.' Citizens consulted their leaders on various issues affecting their lives. On the other hand, consultation between animators and leaders increased but varied from one village to another. This was because the level of conflicts and tensions between leaders and animators in villages varied (see Section 4.2.5). For example, in village $C$, despite the increased participation in meetings, freedom of speech was infringed, a male youth said. 'There was a tendency to accuse community members who were active in the village meetings on criminal offences.' This implies that tensions still existed in the community. It was observed that the level of consultations was different between the villages where the Chukua Hatua project was implemented before the current project, compared to those villages where Chukua Hatua was not implemented. In villages where Chukua Hatua was implemented, leaders were familiar with the concept of animation, and consultation between animators and leaders was an ongoing practice. The animators used consultations as a way of following-up on issues agreed on in various meetings. The use of consultation helped to resolve conflicts that emerged at the early stages of engagement in the four cases. Moreover, consultations between animators, citizens and LGAs improved as the relationship strengthened over time.

Online platforms contributed to the dialogues. In three of the four cases, there were village WhatsApp groups. For example, in village B, a WhatsApp group was formed by the citizens on spearheading development activities in the village, and the animator was amongst the initiators of the group. The animator in village B said, ' $A$ WhatsApp group was formed by the current youth age set and has contributed towards improvement of social infrastructure in the village, such as improvement of water suppl.' WhatsApp groups helped to increase the space for citizens to engage in dialogue with less control. A leader in village A said, 'These villagers have gone far enough to create a WhatsApp group known as "Village A Development Group". The group is composed of both villagers residing in the village and those who are outside the village. Through the group, different development agendas are discussed, mobilization is facilitated, and interventions are proposed and forwarded to the village government for approval and implementation.' The WhatsApp groups gave villagers (both residents and non-residents) an opportunity to give their views on the issues that affect their community. The use of WhatsApp groups was particularly strong in Arusha and area D. In village $\mathrm{C}$, the use of Twitter was predominant and effective; for example, the animator remarked, 'We tweeted about the shortage of teachers in primary schools and in less than three months, three teachers were posted.'

Likewise, Twitter, live streaming and radio promoted dialogue between citizens and duty bearers. The influencers had a great role to play in dialogues conducted online. They led conversations between duty bearers and citizens. One of the project partners explained that YouTube live streaming was used in discussions between duty bearers and citizens across Tanzania. The social media influencers were used in moderating discussions in both live streaming and Twitter (see Section 4.2.4 for more on this). 


\subsubsection{Accountability}

Online and offline platforms raised awareness amongst citizens on their rights, and enhanced accountability and responsiveness among leaders and citizens as shown in Section 4.2.1. Citizens had the capacity to call out leaders either through online or offline platforms, and thus improved transparency. In village B, an elderly man said, 'The village leaders present all the matters related to the village in the village assembly.' Another one added 'Village leader present income and expenditure report'. In village $\mathrm{C}$, the ministry responsible for contraction and a citizen engaged in a conversation on Twitter. Box 4.1 shows another example of the use of online platform in village $C$ for accountability. There were responses on various issues, for instance the number of meetings conducted increased, there was improvement in the mode of presentation on income and expenditure reports and on giving feedback on issues raised by the citizens. In area $D$, an elderly man highlighted that: 'The animators sensitize both male and female citizens to attend meetings that are

Box 4.1: Use of Twitter for accountability

'Village $C$ had a shortage of desks and students had to go to the school with traditional stools; we posted this news on Facebook and Twitter; citizens questioned leaders and leaders solved this due to animators' efforts.' Tweet posted in July 2018 by an animator.

conducted twice per month, and the attendance has been increasing over time.' An animator in village $C$ said, 'We managed to tweet about the land conflict that occurred at our village then the leaders from the districts came to rescue the situation.' Additionally, there were improvements in delivery of services to the citizens in all the four cases. For instance, a youth in area D said 'We thank Oxfam for coming with this programme. Before the programme, responses on various issues related to WASH were taking a long time. For now, it really takes a short time.'

\subsubsection{Use of digital tools}

The use of digital tools contributed to reaching the top leaders, such as district and regional leaders, ministers and permanent secretaries. Most of the animators showed the ability to use digital tools to reach and raise the voice of the citizens. The main online platforms used were Twitter and WhatsApp. Twitter assisted animators to reach government officials and other stakeholders. Through Twitter, animators created networks with different people and groups. WhatsApp was mainly useful in local discussions at village level (three of the four cases). Thus, it gave citizens space to discuss their challenges. Some of the LGAs were included in these WhatsApp groups. The major setback was that few citizens and leaders own smartphones in village $\mathrm{C}$. An animator responded that 'we do not tag our village leaders when we tweet because they do not own smartphones'. A female citizen in village B said, 'I can't afford to buy smartphones.' Another woman in the same village said, 'How can I buy a smartphone while I cannot meet household expenses? This implies that the major reason for not owning smartphone is inadequate income. The quantitative survey indeed shows that in September 2017, only 5 percent of women and 10 percent of men citizens owned a smartphone in the 19 project villages included in the survey (see Section 4.1.2). As a result, such discussions were limited.

WhatsApp groups were used by animators to coordinate and share information. An animator in village B said, 'Through animators' WhatsApp groups, we discuss different issues and challenges facing our communities and how to solve them.' This was important for sharing experiences and enhancing knowledge among the animators. The regional animators' WhatsApp group was useful for discussing the common issues in the region and thus were stronger than national WhatsApp groups.

As mentioned above, the YouTube live streaming and radio programmes supplemented the use of online platforms through smartphones and offline activities in identifying issues, disseminating information, discussing and finding solutions for various issues related to social services and human rights. Social media influencers were involved in the wider 
dissemination of information through Twitter. The animators tagged influential people, including social media influencers in order to reach more viewers. A partner said, 'Social influencer and activist helped a lot in sharing of information by re-tweeting the messages from animators.' An animator in village $\mathrm{C}$ remarked, 'It took us a long time to realize the importance of social media influencers.'

\subsubsection{Changes in relationship}

In most cases, the relationship between citizens, animator and leader was bad at the onset of the project but improved over time. For instance, a leader in village B said 'Leaders (local government) were ignoring the efforts and power of the youth, currently, they changed and work together with youth and community as a whole.' While the citizens in village C said, 'We see that the relationship between leaders and animators is not good. Leaders feel that the animators are interfering too much in too many issues in the village, especially their close follow up on different village matters.' The extent of conflicts and how it came to improve differ from one case to another. One of the reasons for conflict between animators and leaders was animators owning smartphones while the LGAs did not. Moreover, animators shared information on social media without consultation with leaders. In Kigoma the conflicts between animators, leaders and citizens were worse compared to Arusha. This is because, the project related to animation was new in Kigoma compared to Arusha where the Chukua Hatua project was implemented before. Moreover, the conflict between animator and citizens was due to misinterpretation of the activities of the role of animator by the citizens. For example, an animator in village $\mathrm{C}$ said, 'Citizens misinterpreted our activities at the beginning. They thought that we were spies. With time, they came to understand us and appreciated our efforts.' In Kigoma, Oxfam coordinators played a vital role in minimizing conflict between animators and local leaders through continuous consultation with both parties. A leader in area D said, 'At the beginning, animators were an obstacle; they did not understand their roles. Oxfam coordinator convened a meeting with animators and zone leaders.'

\subsubsection{Inclusiveness and equity}

The process of citizens' engagement promoted inclusiveness and equity in the community in all four cases. The use of online platforms complemented with offline platforms allowed citizens, including young women and men, and older women, to raise their voices without discrimination. These citizens were empowered to know their rights and have the power to make leaders understand that they have equal rights to remedy any matter related to the delivery of and access to social services. In addition, the animators ensured that there was a fair distribution of all the social services available, including a clean and healthy environment in area $\mathrm{D}$. The animators followed up on ensuring boys and girls go to school, and there was increased school attendance in village B. For instance, a female citizen in this village said 'We experience improvement on education. Children go to school and the construction of another primary school is in progress.' In addition, women were able to report matters related to gender violence, as evidenced by an animator in area D: 'There was a woman who was accused by her husband of giving birth to baby girls only. She was chased away from home. We recorded her story and sent to the coordinator, who forwarded the issue to IRC, which is the responsible organization. Moreover, there was a woman whose house was burnt by unknown people. We did the same.' 


\subsubsection{Sustainability}

The promotion of human rights and improved access to social services through citizen engagement with the use of online and offline methods resulted in transformation at individual, institutional and village level. At village level there has been a change in mindset, whereby citizens have been empowered to use their voice. This was evidenced by a youth citizen in village A who said, 'I took some photos during the cholera outbreak at the village and shared on my Facebook page and village WhatsApp group.' And leader in village A who highlighted the role of the WhatsApp group (see Section 4.2.2). At institutional level the use of social media and follow up fostered responsiveness and accountability amongst duty bearers (for instance Box 4.2 shows a citizen query to the permanent secretary during an online debate). At individual level, the animators were regarded as leaders because of increased confidence and sharing of information through social media. The confidence gained over time in connection with LGAs and top government leadership motivated the active citizens to continue using social media on sharing matters related to their villages and upscaling themselves to social media

Box 4.2: Active citizens' participation in online debate and tagging of social media influencer

'What efforts has your ministry taken in preparing charco-dams for pastoralists in the arid regions of this country, to support access to water for livestock and herders?' Tweet posted in September 2018 and retweeted. influencers. The animators showed the passion to continue. The animator WhatsApp group is turning into a strong network. They have elected leaders and they were making contributions as a strategy for continuity. Moreover, some of the animators gained popularity in their areas and they were expected to be leaders in the future. The experience showed that some animators from the Chukua Hatua have become political leaders, for instance in one village, the Ward councillor was a former animator. However, it was noted that such leaders did not accept the current animators. Some of the animators are still tweeting after the completion of the project (e.g. Box 4.3).

\subsection{TWITTER DATA ANALYSIS}

\section{Authors: Nicole Schwitter and Ulf Liebe}

The analysis of the Twitter data aimed to investigate to what extent influencers and animators from the four different regions use Twitter, what issues they raise and discuss, if and how others engage with their content, and to what extent animators and influencers are linked to specific key stakeholders.

\subsubsection{Tweeting behaviour}

Figure 4.3 plots the number of tweets per user in the dataset, distinguishing animators and influencers. The data cover a time period of 10 years of Twitter activity. As the analysis is restricted to active Twitter users, the minimum number of tweets of animators is 1 (influencers: 790 ). The median is 28 , suggesting that 50 percent of animators have made 28 tweets or more. The mean of 156 tweets and the maximum of 4,288 clearly shows that the distribution of tweets is skewed. Influencers tend to be a lot more active on Twitter (median: 5,774; mean: 4,646; maximum: 6,398). It needs to be noted that the maximum number of tweets retrievable is capped by the Twitter API (see also Section 3.4.2). Even though animators tend to have joined Twitter much later than influencers, the activity level of some 
has grown to be comparable to those of influencers, as five animators have made over 1,000 tweets (all of them coming from either Mtwara or Kigoma).

Figure 4.3: Distribution of number of tweets made per user

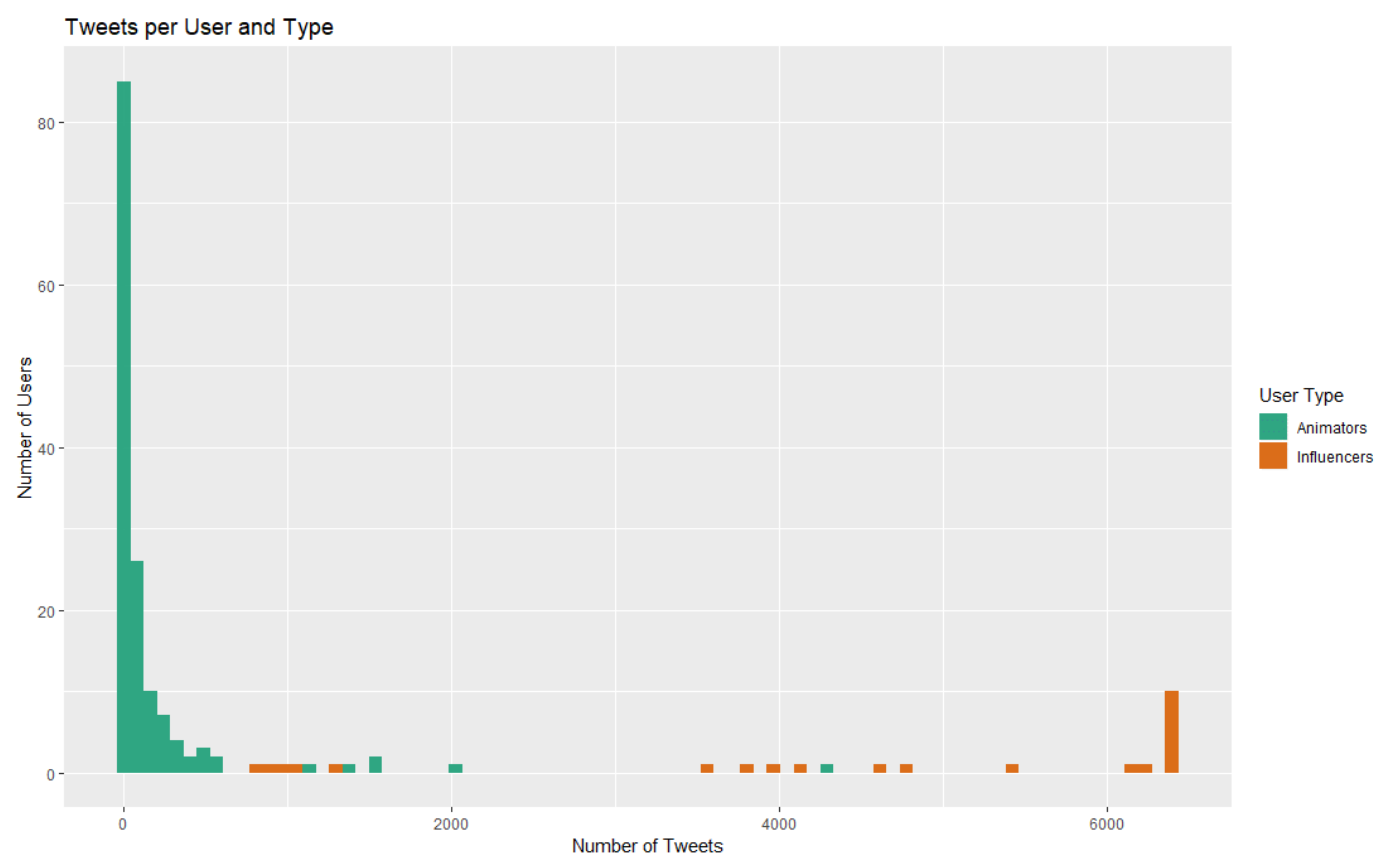

\subsubsection{Tweeting behaviour over time (after April 2017)}

Figure 4.4 shows the relative frequency per tweets of the animators in all of the four regions (number of tweets per day divided by the number of active Twitter users). Areas shaded in red refer to days of trainings organized in the setting of the project as well as to the animator summit (see Section 2.2). Clearly, tweeting behaviour is spurred by an Oxfam workshop. The workshop on digital tools was handing out smartphones to the animators and teaching them how to use them and social media, which had a clear effect on Twitter activity: before this workshop in October/November 2017, we observe next to none.

Over time, we observe levels of tweeting activity that are rather stable, but comparably low in Geita and Arusha. More activity is observed in Kigoma and Mtwara. These regions also show large variation in the frequency of tweets and some remarkable peaks in activity. Up until May 2019, tweeting activity is ongoing, even though airtime support through the project ceased at the end of March. 
Figure 4.4: Tweeting behaviour of animators over time

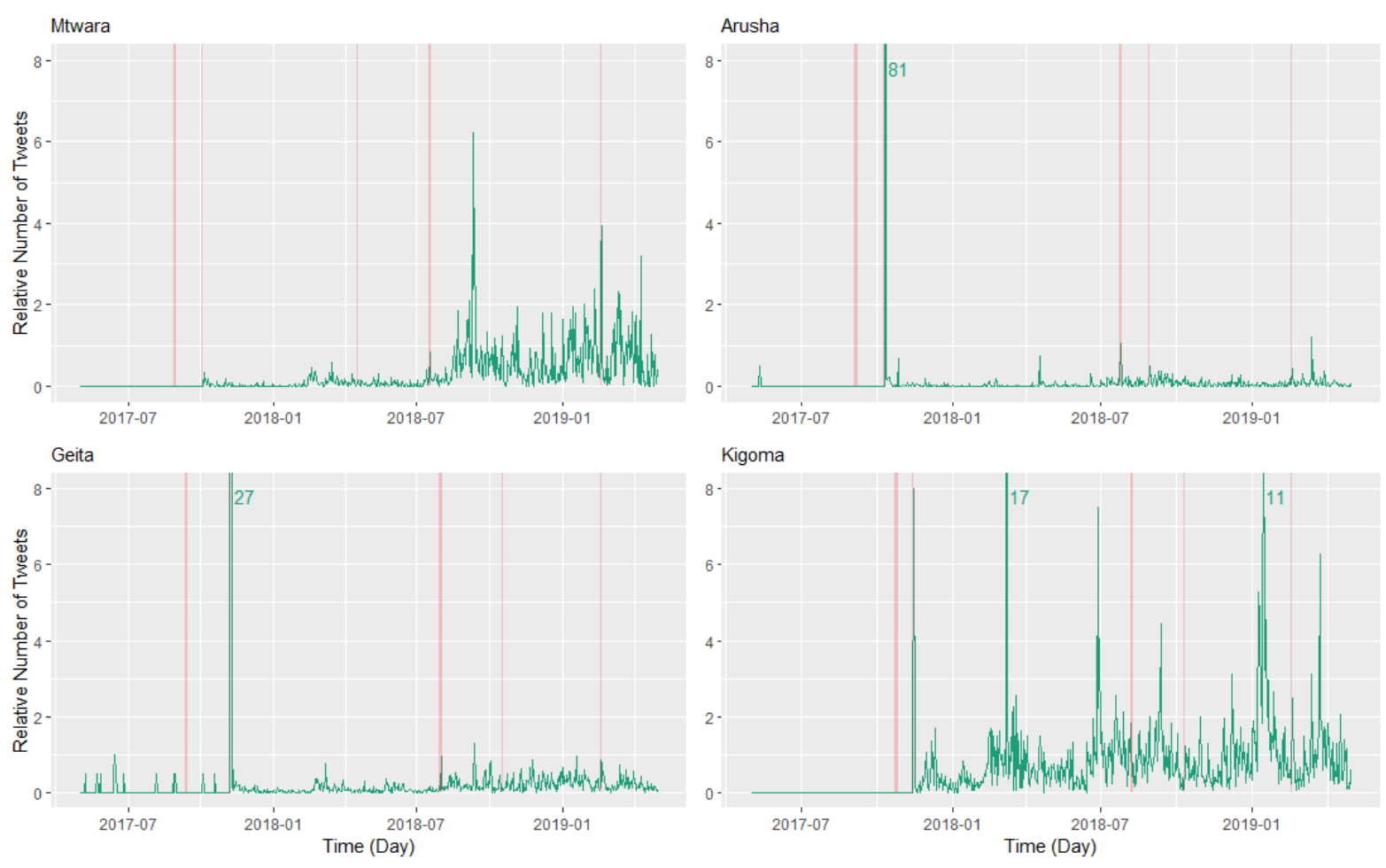

Due to the data restrictions employed by Twitter, the very high activity of some influencers, and the gaps between the dates of the data collection, changes in number of tweets over time of the influencers cannot be interpreted in an insightful way, as changes are in part just artefacts of these data limitations.

\subsubsection{Contents of tweets}

To understand which issues were raised by the involved Twitter users, the text of the tweets has been analysed. In Figure 4.5, word clouds are shown, which display the most often occurring words in the tweets (excluding stop words, the most common words of a language).

Word clouds for the four regions have been created separately. The word clouds of the animators make it clear that they mostly tweet in Swahili. The name of the project itself Chukua Hatua (take action) - is the most often occurring term in all of the tweets in all regions. Also, many tweets link to the Twitter account of Oxfam Tanzania and to relevant people, such as @billmarwa and local and national leaders. Tweeting behaviour of the animators seems thus highly linked to the project. They further mention a number of different societal issues: Terms such as ukatili (violence), serikali (government), mazingira (environment), afya (health), wanawake (women) or maji (water) are among the most often used words in all of the tweets.

A similar word cloud has been constructed for the influencers in Figure 4.6. Again, chakua hatua is the most occurring term in their tweets and different issues are raised. It can also be noted that some influencers post in English. 
Figure 4.5: Word clouds by region

\section{Mtwara}

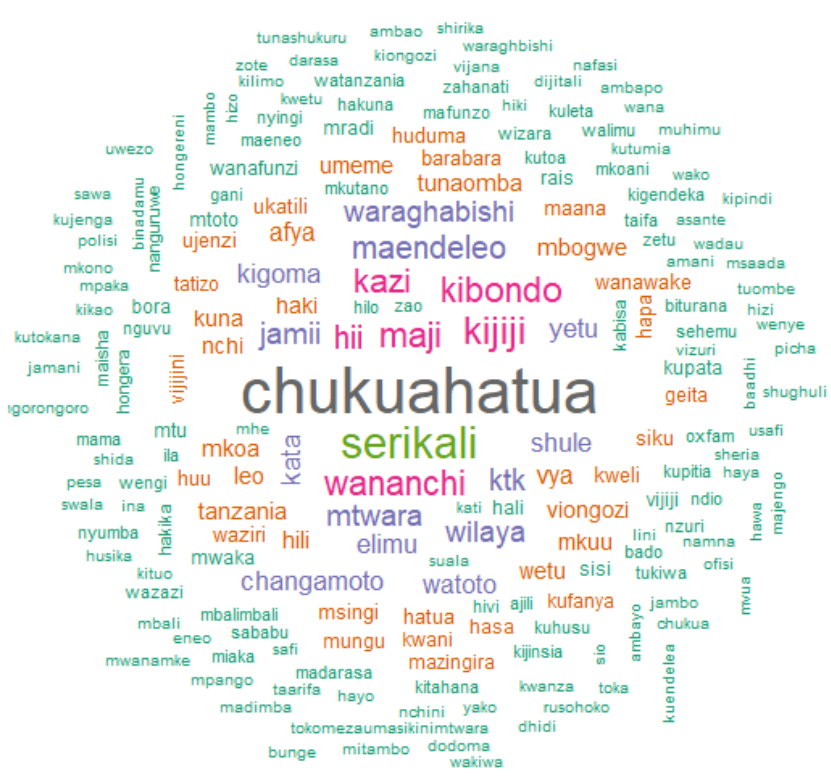

\section{Geita}

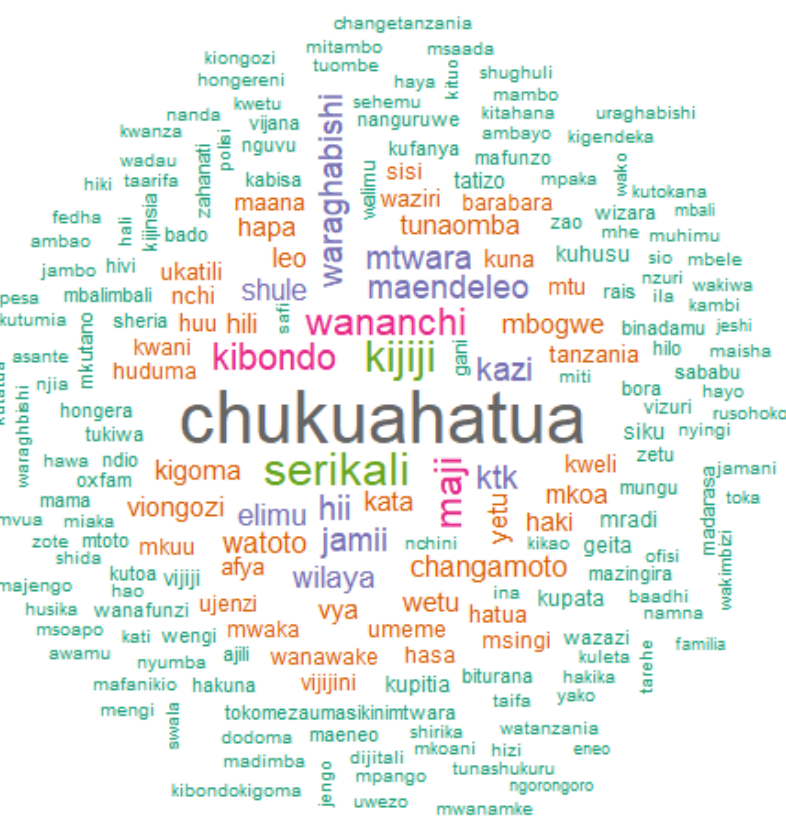

\section{Arusha}

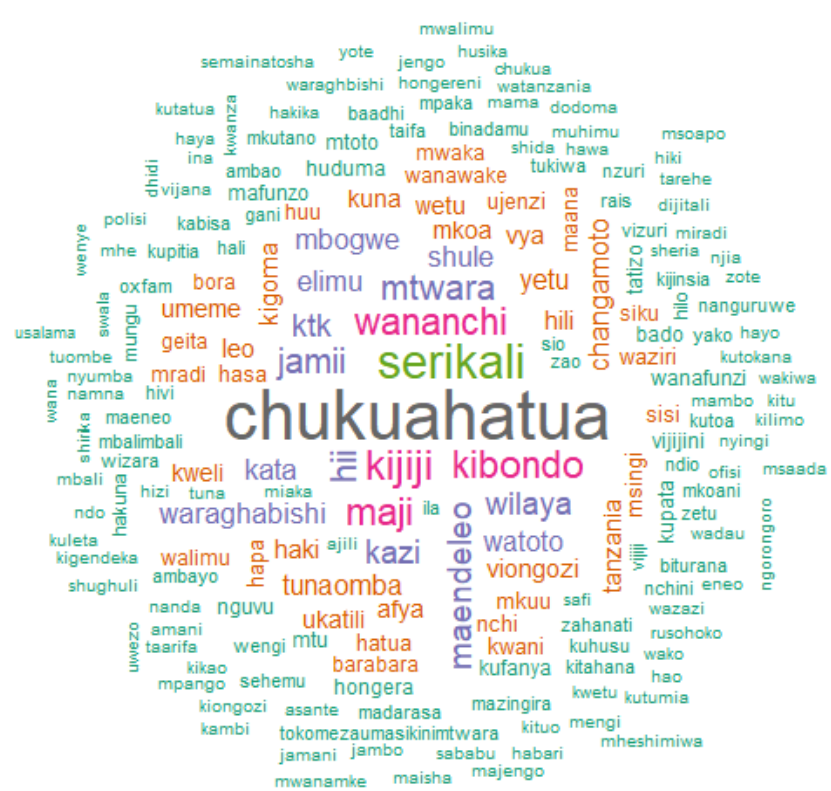

Kigoma

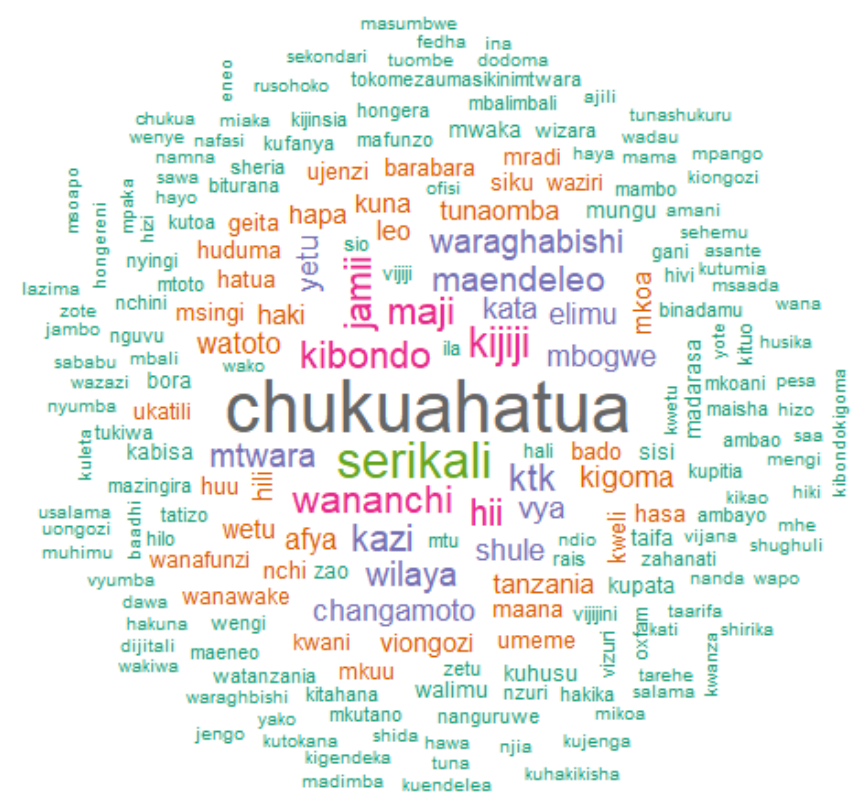


Figure 4.6: Word cloud of influencers

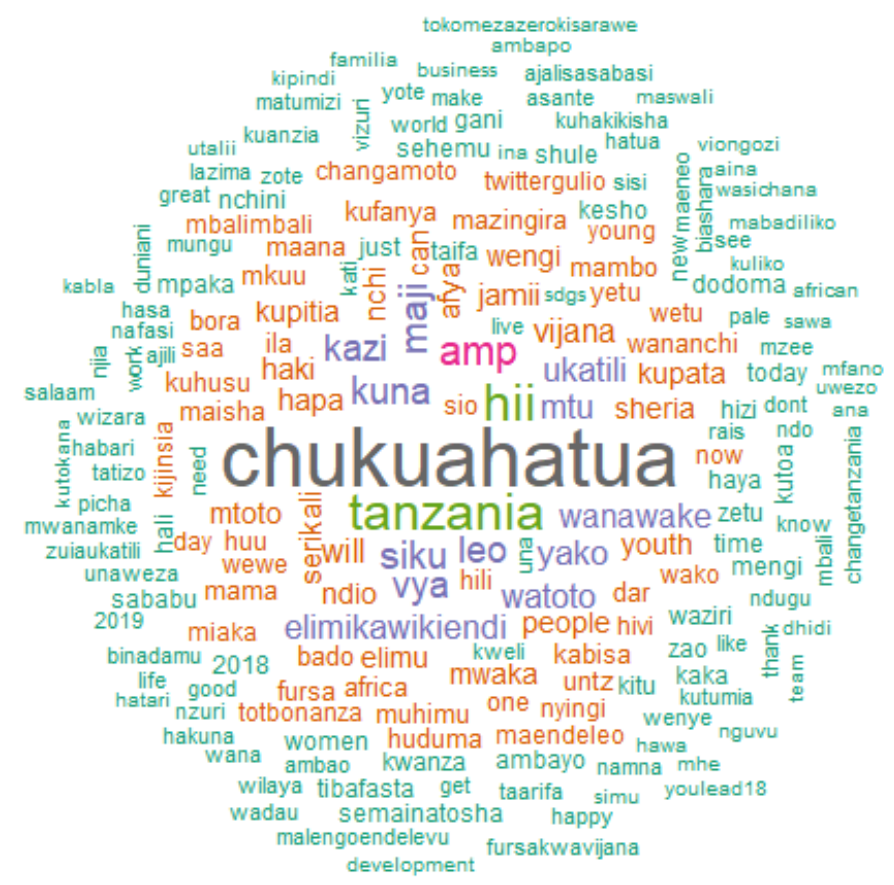

\subsubsection{Engagement with tweets}

One of the key areas of interest lies in exploring the level of engagement the animators have achieved on Twitter. In the following discussion, engagement is defined as the sum of likes and retweets on Twitter.

The amount of engagement varies between 0 and 508,357, with a median of 5 and a mean of 161.8. As these numbers suggest, the distribution of engagement by tweets is highly skewed. A large number of tweets provoke no reaction while others become extremely popular. This is the case for both animators and influencers, even though it is more pronounced for the influencers (median animators: 5 , mean animators: 40.84 , maximum animators: 141,315. Median influencers: 5, mean influencers: 186.7, maximum influencers: $508,357)$. As extreme cases of viral tweets would drive the statistical results, we exclude outliers from the analysis, defined as the 1 percent of the tweets that have received the most engagement. Restricting the analysis results in a median number of tweets for the animators of 4 (influencer: 5), mean of 12.53 (influencer: 21.09), and maximum of 883 (influencer: 896). The pattern still shows that tweets of influencers are, on average, more popular (see Figure 4.7; note the log scaling of the $y$-axis). However, some tweets in both groups received much attention. 
Figure 4.7: Violin plot of engagement

Engagement per Tweet

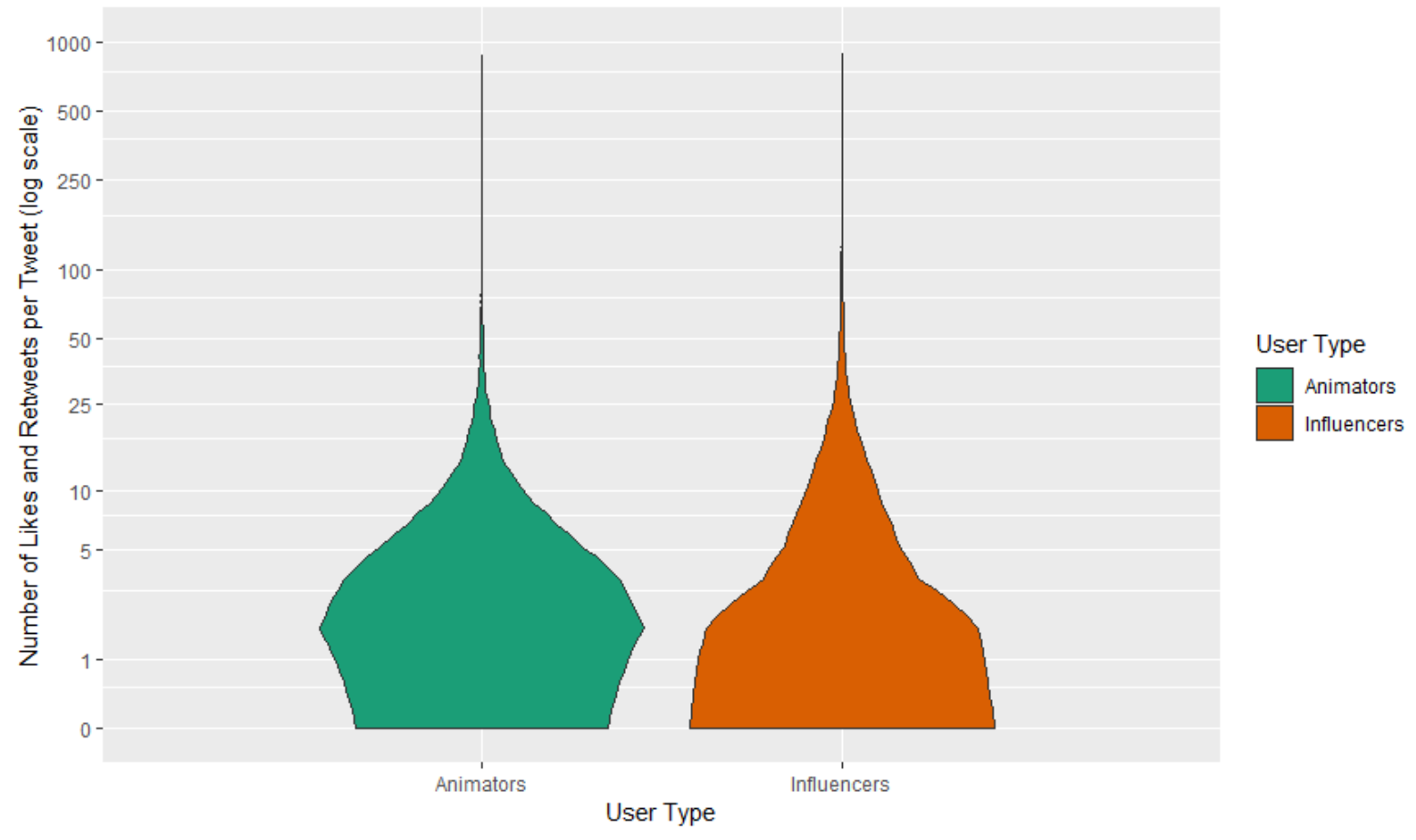

Figures 4.8 and 4.9 show how the rate of engagement (defined as engagement on tweets posted on a given day divided by total number of tweets posted on a day) has changed over time for the animators and the influencers, respectively. The tweets of the animators have started to receive engagement once they have started tweeting following the Oxfam workshops. While there is certain variation, there is a general increase of a base level of engagement, in particular in Mtwara. The influencers receive in general a higher level of attention which also shows variation over time.

Figure 4.8: Rate of engagement over time: animators
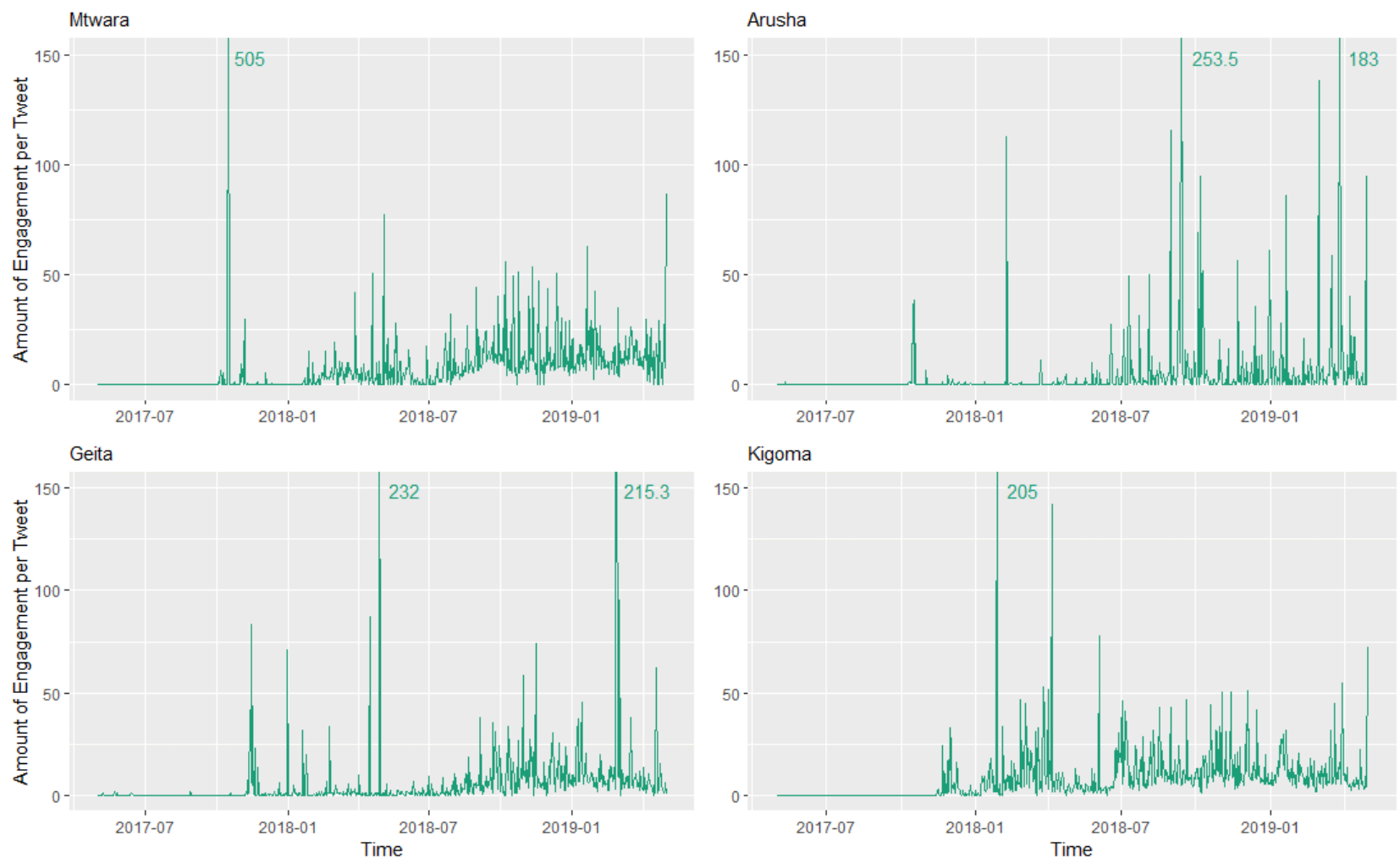

Governance and Accountability through Digitalization in Tanzania Impact Evaluation 2017-2019 
Figure 4.9: Rate of engagement over time: influencers

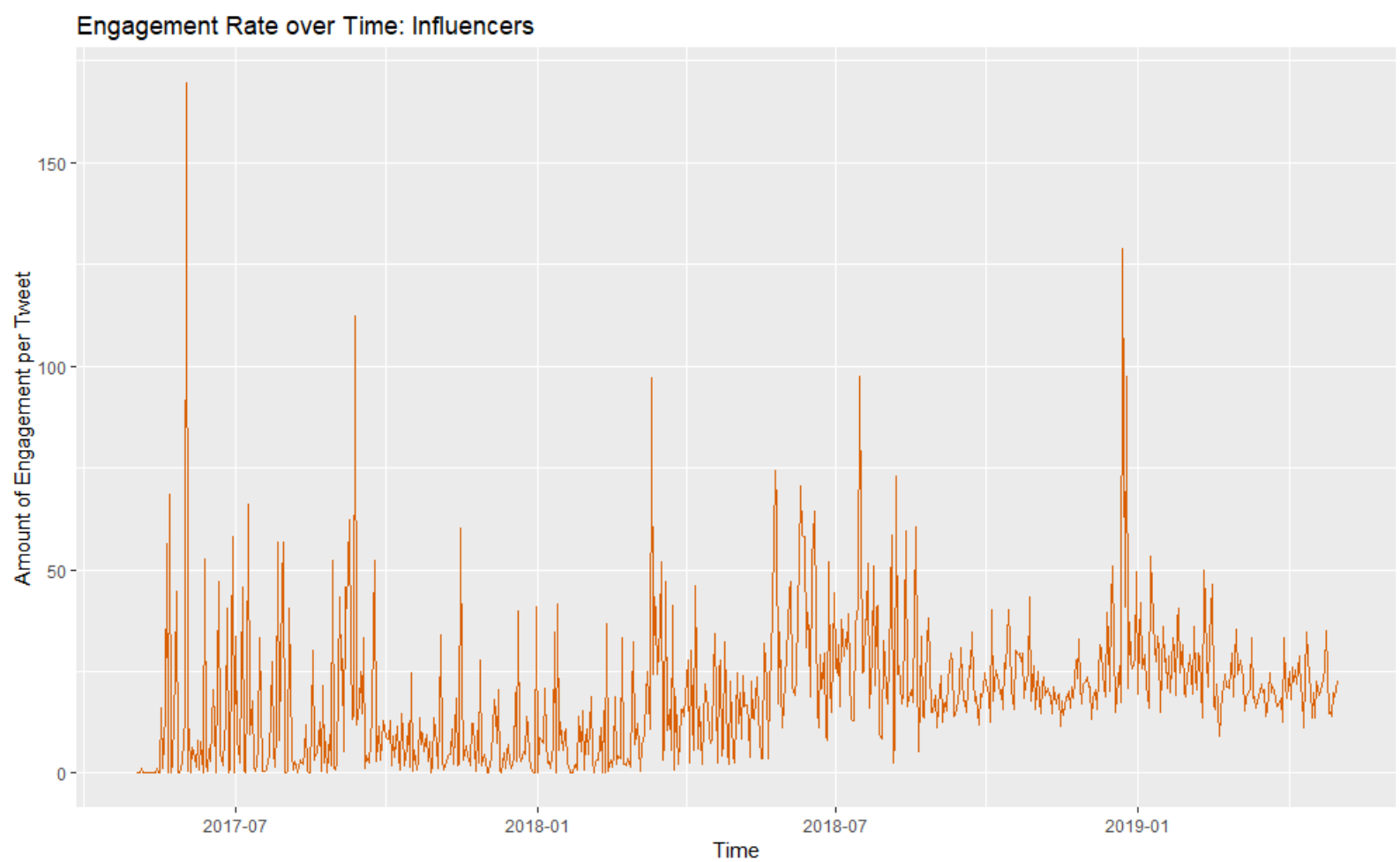

Finally, it was of interest to explore what characteristics of tweets determine the attention they receive. Figure 4.10 shows coefficient plots for multilevel regression (taking into account that tweets are nested into users) with the dependent variable being the logarithm of the amount of engagement. Results of the regression model confirm the previously described results. They show that tweets posted by influencers receive on average more attention than tweets posted by animators. As the binary variables for time in months suggest, the rate of engagement has increased over time. While there seems to be a downward trend in the most recent months, it is important to note that there also simply has been less time to engage with them. Furthermore, tweets posted on Wednesdays are significantly more popular than tweets posted on Mondays. 
Figure 4.10: Coefficient plot of determinants of engagement

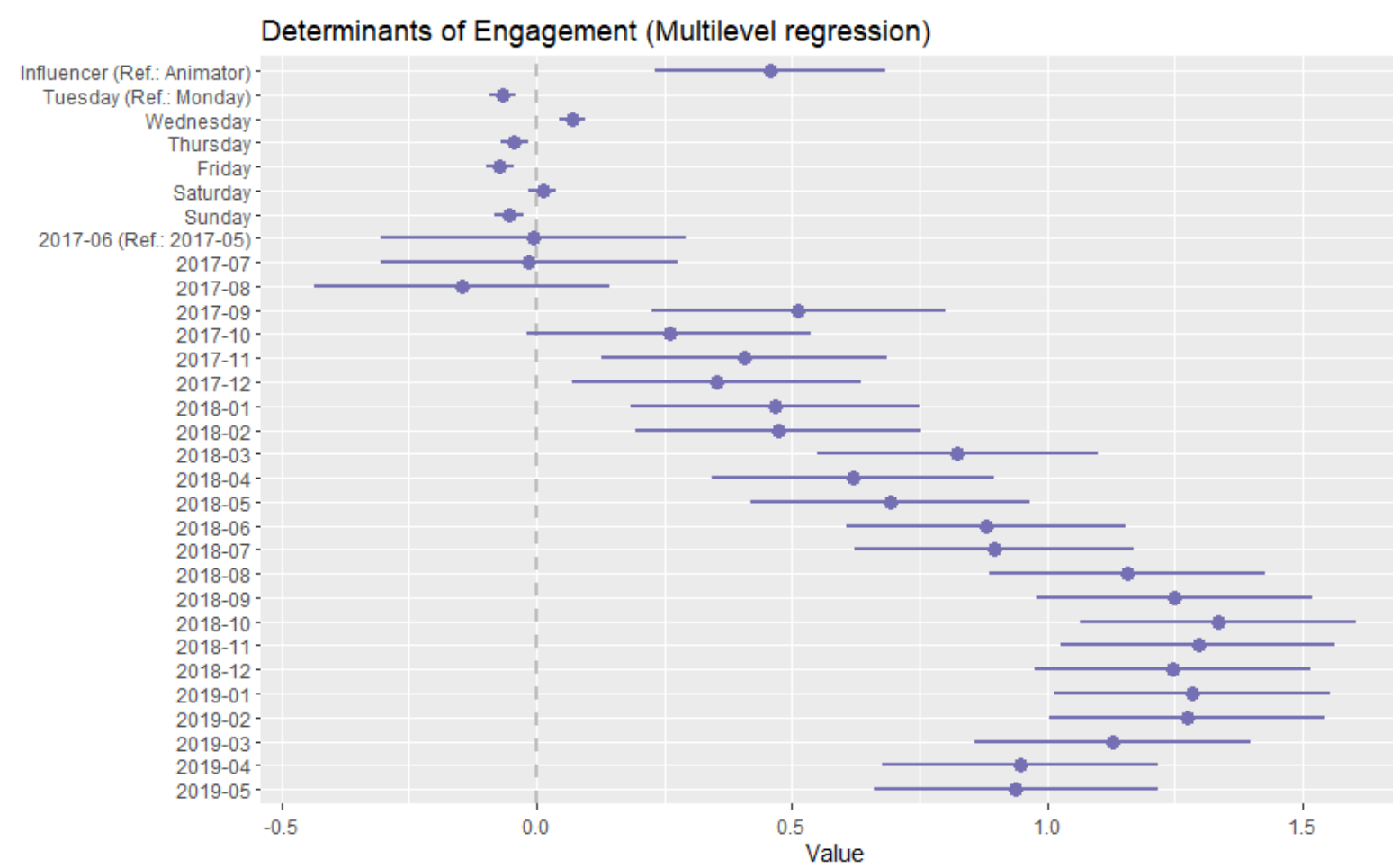

Note: Number of observations (tweets): 130942; number of groups (Twitter users): 166. Log likelihood: $215410.6(\mathrm{df}=34)$

To explore how the content of tweets influence their popularity, further regression models were calculated, which explored whether mentioning a certain topic and/or using a hashtag increased the engagement. Figure 4.11 shows the results (controlling again for user type, week day and month dummy as in previous model, coefficients not shown). If a tweet includes the words ukatili, ardhi, wanawake or afya, it tends to receive more engagement than when a tweet does not include these words, but the effects are not significant. However, using the hashtag \#chakuahatua leads, on average, to significantly more engagement. Tweets that have used the project hashtag receive more likes and retweets than tweets that do not use the hashtag. Hashtags on Twitter work as a mechanism to link tweets to a topic and increases a tweets findability/discoverability through the search. 
Figure 4.11: Coefficient plot of determinants of engagement

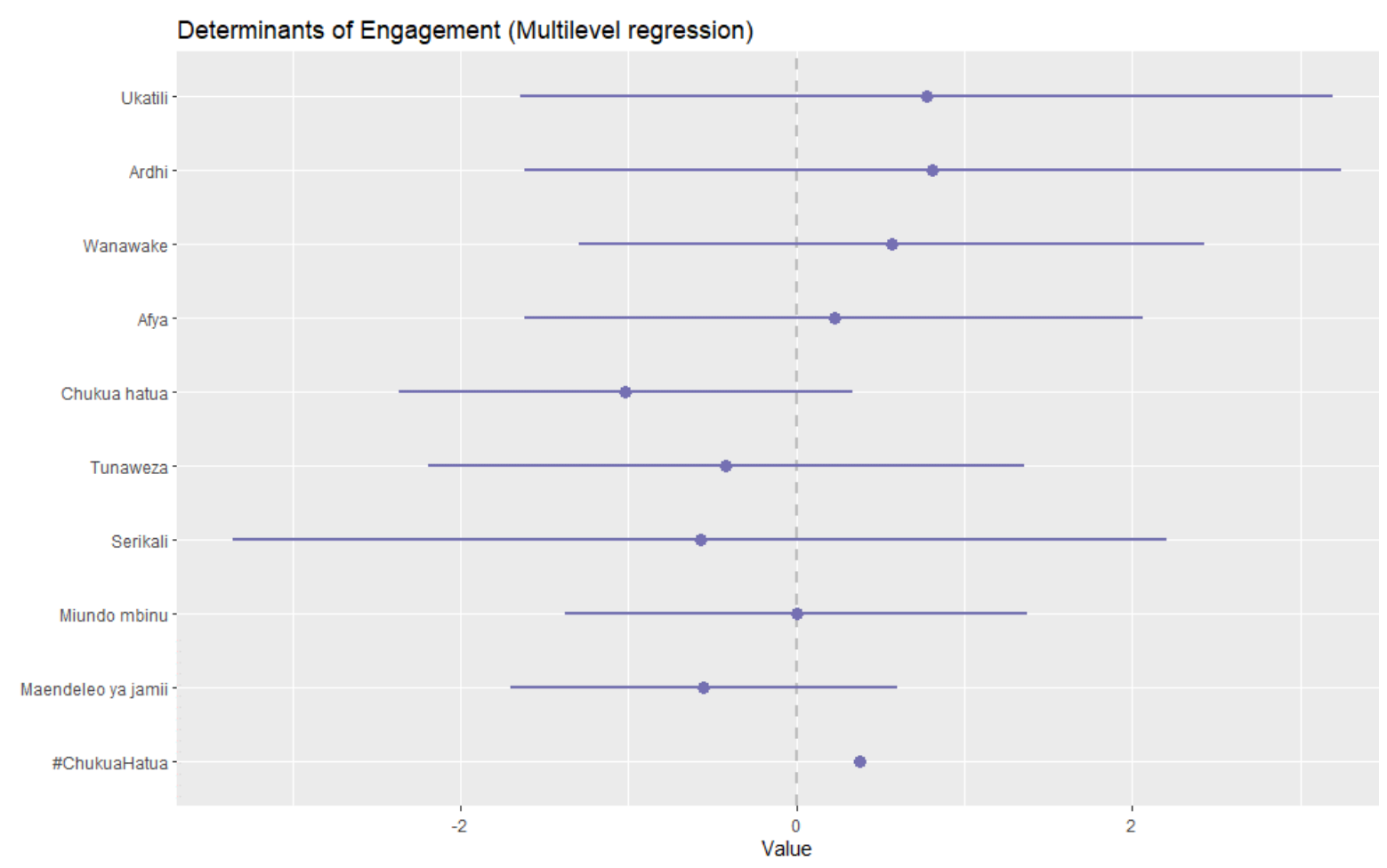

Note: Number of observations (tweets): 130942; number of groups (Twitter users): 166. Log likelihood: $215162.4(\mathrm{df}=44)$

\subsubsection{Network with key stakeholders}

A number of government officials, service providers, NGOs and CSOs are using Twitter, and it was of interest to explore which - if any - of these organizations and key stakeholders follow the animators and influencers on Twitter. The network of interest is thus a bipartite network in which only ties between these officials and animators/influencers are explored while ties within these groups are neglected. The network is treated as undirected as only one direction (officials following animators/influencers) is taken into account.

Figure 4.12 shows that the majority (103 out of 169) of users are not followed by any official accounts. Figure 4.13 is restricted to animators and influencers with relations. The officials are further classified into five subgroups: 1) national level leaders (e.g. ministers or the president), 2) local level leaders (e.g. regional commissioners), 3) national companies and public agencies (e.g. service providers), 4) Tanzanian NGOs or CSOs coalitions and 5) Oxfam and partner CSOs. Figure 4.13 shows that most of the animators and influencers that are followed have only one official account following them; only few are followed by several official accounts. In total, 22 key stakeholders and organizations follow at least one of the animators or influencers in the project, but only four have comparatively many $(>15)$ ties: three of those accounts are partner institutions while one of them is a national minister. 
Figure 4.12: Network of key stakeholders and animators/influencers

- National Politicians

- Regional Politicians

Companies and Agencies

- NGO/CSO Coalitions

Oxfam and Partners

- Animators

Influencers
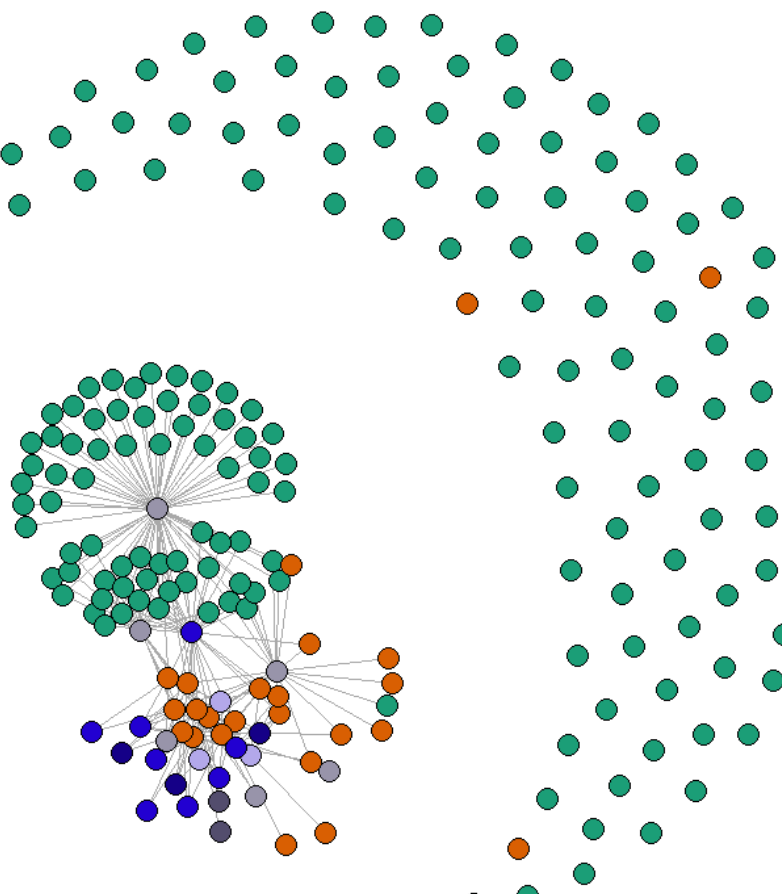

Politicians

- Regional Politicians

Companies and Agencies

- NGO/CSO Coalitions

Oxfam and Partners

- Animators

Influencers 


\subsection{DIGITAL TECHNOLOGIES AS ENABLERS}

Drawing from the qualitative case studies report, Sections 4.1 to 4.3 and additional quantitative analysis, this section brings together the evidence available to test the eight assumptions laid down as the main mechanisms for digital technologies to enhance the animation model. The quotes come from the qualitative case studies report (Towo et al., 2019) which discusses in more detail how each mechanism materializes in the four cases.

\subsubsection{Inviting/informing citizens in a more efficient manner}

Both the qualitative and quantitative analyses show that most of the informing or mobilizing of citizens is happening offline, with only 7 percent of citizens who own a smartphone at baseline in the intervention group, and 15 percent of men and 6 percent of women who use social media in the intervention group at endline. From the animators' perspective, the quantitative data also does not confirm that the use of ICT makes the invitation process more efficient than in the comparison group.

Drawing from some of the best examples of mobilization, the case studies show that there could be potential for this in the future: "an animator said, "We have a WhatsApp group that help us in mobilizing citizens to participate in development initiatives. Youth are more active." The groups were used in sharing and disseminating of information to citizens and leaders.' (Towo et al., 2019). Age is indeed identified as a key characteristic of citizens using social media, through the quantitative data.

\subsubsection{Creating new spaces for discussions with less direct control}

Similarly, the qualitative and quantitative results show that only a few citizens access online spaces. 'There were village WhatsApp groups. These groups helped to increase the space for citizens to engage in dialogue with less control. The WhatsApp groups gave community members (both residents and non-residents) an opportunity to give their views on the issues that affect their community.'(Towo et al., 2019)

Significantly more animators use WhatsApp and Facebook groups on local issues as a result of the project (the project increases the share of animators using such group by 73 percentage points, and by 65 percentage points respectively). When restricting this analysis to animators who use social media, we observe a sharp significant increase in the share of animators who are part of a Facebook group on local issues as a result of the project. This means that this space particularly has been more invested in by animators as a result of the project.

\subsubsection{Searching for information}

As per the previous mechanisms, take-up at citizens' level is limited. However, we also note that citizens are significantly less likely to access information about access to services from an online platform (decrease of 4 percentage points, significant at 1 percent. Table not shown; available upon request).

Animators, however, are much more likely to access information on their own rights or rights of others in their community (an increase of 48 percentage points, significant at 1 percent) and on access to services (an increase of 34 percentage points, significant at 5 percent) through online platforms as a result of the project. This is confirmed by the qualitative case studies: 'Most animators used their smartphones in searching for information. Animators from [the four cases] asserted that they were using their smartphones in visiting search engines like Google and social media like Twitter and Facebook. An animator in village B said, "Since I got this smartphone, it's like the world is in my hand".' (Towo et al., 2019) 


\subsubsection{Receiving information, provided by other animators or active citizens}

We also observe that animators are much more likely to access information on their own rights or rights of others in their community through talking to someone they know (face to face or over the phone) as a result of the project (an increase of 43 percentage points, significant at 1 percent), but as likely to access information on access to services through this channel. The qualitative case studies highlight the importance of the use of online platforms to share info among themselves, such as WhatsApp groups, Facebook or Twitter. 'An active citizen from village $\mathrm{C}$ said, "I took some photos during the cholera outbreak at the village and shared in my Facebook page and village WhatsApp group". Animators shared information among themselves through WhatsApp groups.'(Towo et al., 2019)

\subsubsection{Receiving information provided by Oxfam and partners through the project app}

This mechanism was not implemented as the project app was designed and developed during the project.

\subsubsection{Accessing new spaces to call out leaders online in the presence of outsider witnesses}

Animators are more likely to use social media to be part of conversations with leaders and officials as a result of the project (increase of 49 percentage points in the share of animators, significant at 1 percent). The qualitative case studies highlight that the main online platforms used to call out leaders were Twitter and WhatsApp, with regional differences on the use of different platforms (which the Twitter data analysis also shows). Overall, Twitter is identified as the platform to reach national-level leaders or stakeholders. The word clouds presented in Section 4.3.2 show that the president and other officials are tagged in the tweets, while most animators are not followed by officials directly (Section 4.3.3). In some regions, Twitter is also the platform to reach regional or district-level leaders, while in other regions, WhatsApp groups, which include the district, ward or village leaders, were formed and used to call-out leaders. Different online platforms were hence used for different purposes, depending on the regional context - which leaders use a given platform and the perceived sensitivity to call-out leaders publicly in a setting of shrinking civic spaces.

In the Nduta Refugee Camp, a citizen said that 'the use of online platforms helped us to get immediate response from leaders and service providers'. However, as mentioned above, while there is interest and involvement of some citizens, at scale, the project is not making a significant impact (citizens in both groups are as likely to use social media to be part of conversations with leaders and officials, and this is less than 2 percent of citizens in the intervention group).

The qualitative case studies also highlight that in one region in particular, radio programmes on community radio were used for citizens' to call out their leaders. YouTube live streaming sessions also promoted discussions between duty bearers and citizens across Tanzania. The Twitter data analysis also shows that tweets posted on Wednesdays (when these sessions took place) are significantly more popular than tweets posted on Mondays. Wednesdays were the days were such debates were organized.

\subsubsection{Coordination between animators is more efficient (quicker) and animators are more connected}

As a result of the project, the share of animators who discussed issues related to rights or access to services with other animator(s) outside of the village has increased significantly (an increase of 40 percentage points, significant at 1 percent). We also observed a sharp increase in animators having checked in with other animators or activists regularly (an increase of 43 percentage points, significant at 1 percent). This is confirmed by the data gathered through the case studies. 'Through WhatsApp groups the animators were 
coordinated. Within the groups they were sharing information on what happened within their respective villages/areas. Discussions within the groups helped animators to improve their knowledge in constructing tweets and identifying challenges facing their communities. An animator said through our WhatsApp groups, we edit our tweets. Furthermore our WhatsApp group is evolving into a strong network".'(Towo et al., 2019)

\subsubsection{Amplifying role of other active social media users}

The qualitative case studies underline the role of social media influencers 'in sharing of information sent by animators to duty bearers. They facilitated animators to reach and capture the attention of the public by re-tweeting as a partner said "social influencer and activist helped a lot in sharing of information by re-tweeting the messages from animators." The influencers had great role to play in dialogues conducted online. They led conversation between duty bearers and citizens. However, most animators had limited access to social media influencers. An animator remarked that "it took us a long time to realize the importance of social media influencers". Furthermore, animators and social media influencers were not connected from the beginning of the project.' (Towo et al., 2019)

The analysis of the Twitter data of the project's animators and influencers indeed shows that online engagement was built over time. The network analysis presented in Section 4.3.3 shows that influencers are more likely to be followed by at least one key account than animators. It also shows the importance of the use of the \#chukuahatua for tweets to get traction. 


\section{CONCLUSIONS}

\subsection{CONCLUSIONS}

The 'Governance and Accountability through Digitalization' project took place between 2017 and 2019 in rural areas in Arusha, Mtwara, Kigoma and Geita in Tanzania. The project built on the traditional animation approach developed through Oxfam's former project 'Chukua Hatua' and enhanced it by the use of digital tools. The impact evaluation analyses the added-value of the digitalization component, compared to traditional animation approach, between September 2017 and February 2019. A quantitative quasi-experimental design explores the impact at scale among citizens, and to a lesser extent, among animators. It is complemented by four qualitative case studies that explore how relationships between the key actors have evolved with the introduction of the digitalization component, among four successful cases of mobilization and outcomes. The data generated on Twitter by animators and other stakeholders was also collected and helped build a broader picture of the project. While each component separately explores different questions, Bringing the three components together contributes to understanding the mechanisms that enabled the changes observed at scale.

As a result of the project, and compared to animators relying on traditional approaches to animation, we observed a change in online practices among the project animators higher usage of social media overall and for animation related activities. Significantly, more animators use WhatsApp and Facebook groups on local issues as a result of the project and use social media to be part of conversations with leaders. This is confirmed by the Twitter data analysis, which shows increasing trend of tweets among animators after the project started, and following key activities of the project, while also showing regional variation on the matter. Different online platforms were, indeed, used for different purposes, depending on the regional context - which leaders or officials use a given platform on the one hand, and the perceived sensitivity to call-out leaders publicly in a setting of shrinking civic spaces on the other hand. The project had a significant impact on animators' connection with other animators within the village and outside. Animators also appeared to be more engaged with citizens than those in the comparison group as a result of the project (meeting-up with citizens for individual conversations, organized meetings with citizens without officials, and with citizens and officials), but equally as likely to participate in village meetings. Eighteen months after the project started, animators were significantly more likely to be willing to keep carrying out animation activities moving forward than animators in the comparison areas.

Among a representative sample of citizens, we observed that women and men citizens in the project villages were more likely to know the village animators as a result of the project, compared to women and men citizens in villages where animators rely only on traditional animation approach. However, their offline engagement with animators or with civic activities (through discussion or meetings with animators, meetings among citizens, meetings with leaders or reporting of issues to officials) was not significantly impacted by the project. In villages where high level of mobilization and visible changes in human rights promotion were observed, transparency of leaders and increased awareness of citizens led to behavioural changes and increased participation in formal village meetings, according to the case studies. Sustained and stronger behavioural change of leaders and citizens will hence be key to see an impact at scale on village meeting participation, opening-up formal spaces to bring about change. However, at scale, the project has had an impact on the topics of the issues discussed in 
community dialogues, as well as the one reported directly to the authorities. In particular, women citizens are more likely to report issues related to violence to the leaders as a result of the project, while men are more likely to report issues related to access to water. Note that these mechanisms lead to different topics being discussed overall, and by women and men citizens in particular, as community dialogues are open and public spaces, while reporting is a private mechanism.

Citizens' access to and use of online platforms is very low - and even lower for women compared to men - and not impacted by the project. The main limitation identified by citizens is the lack of access to devices. However, the qualitative case studies highlight that there is interest, particularly among youth. Through the quantitative data, age is identified as a key characteristic of citizens using social media.

The project contributed to building citizens' sense of 'power to', in particular through the development of individuals' ability to decide for themselves about their participation in community activities, or travelling outside of the community or their attitude in public forum. We did not measure impact on citizens' sense of 'power within', nor on active citizenship, as defined in the setting of the project.

As a result of the project, and compared to villages in which traditional animation was ongoing at baseline, leaders and officials at different levels (village, ward, district) were more likely to open spaces to animators 18 months after the project started. The qualitative case studies show that the relationship between animators and leaders has not been an easy one from the start. There have been conflicts between animators and leaders or officials, and many efforts to build relationships, including through mitigation by the project's team. This seems to be particularly strong in areas where supported animation practices did not pre-exist the project under review.

There is evidence that some aspects of governance at village level have improved (village meetings are more frequent), but citizens also report that leaders are less likely to address the individual issues they reported. At ward or district level, leaders are perceived as more available and transparent by citizens.

As a result of the project, animators are more likely to share stories of mobilization, to share stories in which social media was involved and to judge that the mobilization had a more positive outcome than animators in the comparison group. On the other hand, citizens in the project villages are as likely as citizens in the comparison group to share such stories, and the content of the stories is not different (their own involvement, involvement of social media, outcome of the mobilization). It is important to highlight that overall, citizens are less likely to be involved than animators in the story they shared. The qualitative case studies present in detail four cases of mobilization, which involved the use of smartphones and social media, and which led to actual changes in the village. These are related to school facilities, school staff and land use by a company in two villages in Arusha and one village in Kigoma. In the refugee camp, the qualitative case study describes mobilization supported by the use of smartphones related to water and sanitation infrastructure maintenance, domestic physical violence and sexual violence against women. As this theme emerged from the case studies, we reclassified the stories shared by the animators and found that animators in the project areas are significantly more likely to share stories of mobilization about discrimination or violence against women than ones in the comparison areas.

At scale, there is evidence that the project has resulted in some change in social services, with more areas of social services in which renovation, improvement or building have been undertaken, than in the comparison group (although the total number of renovations or improvements is not statistically significantly different between the two groups), and more plans seem to be initiated for future building or 
improvement. More households have received compensation from a company using their land (small effect size, but significant at 5 percent). The project did not affect awareness of citizens or prevalence of cases of land right violation. However, the project resulted in significantly more awareness of unequal inheritance practices among women, and of marriage of girls under 18 among men and women citizens.

When looking at the assumptions behind the introduction of the ICT component, and what this component was aiming to enable, the data gathered by the different sources help invalidate some assumptions and identify the strongest ones. First, as mentioned above, a very small share of citizens engage with online platforms - and an even smaller share of women - making the online platforms a tool for animators' and leaders' interaction mainly, although the case studies show that there is interest, in particular among the youngest citizens. The ICT component enables animators to access new spaces which are perceived to have less direct control (WhatsApp groups in particular) and to coordinate among themselves, as well as to improve their connectedness and strengthen the network of animators. Animators search information thanks to the smartphones and the internet, and subsequently share it among themselves. Access to Twitter and WhatsApp in particular has enabled animators to access new spaces to call-out leaders. Both platforms are used for different purposes, however, depending on who has to be reached, who will listen and the context specific to each region. The qualitative case studies indeed show that ward or village leaders do not necessarily have access to the technology themselves, which could be a source of tension; in addition, depending on the region, district or regional leaders or officials may be part of WhatsApp groups with animators and citizens, but may not be on Twitter. Overall Twitter has been used to reach national level leaders or stakeholders. The analysis of the data gathered from animators and influencers of the project also shows that engagement was built over time and that the use of the \#chukuahatua was critical for tweets to get traction.

While the impact evaluation is looking at the impact after 18 months of activities, which is a very short timeframe, a key question is about the sustainability of the approach. The evidence gathered shows that in February 2019, animators were willing to keep carrying on animation activities (more so than in the comparison group), and they are still tweeting at the time of writing of the report (two months after the end of the direct project's support). Both the Twitter data analysis and the qualitative case studies highlight that a few animators became as active as the social media influencers by the end of the project. However, drawing from the comparison group trend of changes in behaviour over time, there may be a risk of disengagement. Drawing from baseline targeting process and quantitative survey experience and the qualitative case studies, there also seems to be a trend for animators to become involved in politics after their being involved in such a project.

At citizen level, the sustainability of the project will also depend on leaders' responsiveness over time at different government levels. If renovation plans are not implemented or individual issues reported more rarely addressed, there will be a risk of disappointment and further disengagement. 


\subsection{PROGRAMME LEARNING CONSIDERATIONS}

\section{Identify the current barriers for citizens, and women citizens in particular, to engage with animators and civic activities}

Citizens who are the most likely to know the animators are more likely to be men than women, more likely to already involved in the decision making of community groups than not, and to be in Mtwara and Kigoma, compared to the other regions. Moving forward, understanding the specific barriers that citizens of Arusha and Geita face in engaging with animators on the one hand, and the barriers for men who are not already involved in the decision making of community groups overall on the other hand, will be critical. Similarly, what are the factors that explain the fact that women are significantly less likely to know the animators on the one hand, and to engage with online platforms, and offline civic activities on the other hand? Understanding specific barriers that women face and reasons they put forward for not engaging online or offline will be critical in order to define appropriate strategies. In addition, not all women will face the same barriers (the situation in Arusha and Geita may be different from Mtwara and Kigoma, as mentioned above for example, but also within each village). This will require consulting women and men citizens, and particularly the ones that are not already close to Oxfam, partners, animators or village institutions.

\section{Consider supporting citizens' organizing among themselves}

In the project areas in September 201715 percent of citizens participated in meetings among themselves and 16 percent participated in meeting with animators without officials. This has not been significantly impacted by the project. This is an overall low share of citizens while Chukua Hatua's first pilot identified 'the lack of spaces and forums for citizens to discuss their accountability issues among themselves' as a struggle to be tackled (Oxfam's Rights to be heard framework, Hopkins et al., 2014). In the absence of widely owned informal closed spaces for citizens, and given that such online spaces, such as WhatsApp groups, are not available to most citizens but are to animators, there is a risk of the animation approach to becoming very centralized and somehow disconnected from the citizens. Moving forward, it will be key to identify how to strengthen the link between animators and citizens, and make sure that animators open up safe spaces - which they are part of or not - for women and men citizens to organize and contribute to setting up their reform agenda.

\section{Strengthen the project's strategies to support relationship-building between animators and leaders, at village level in particular, and to mitigate risks for animators}

While animators are accessing technology through the project, village- and ward-level leaders (and sometimes higher level as well) do not have access to such technology, and this was sometimes perceived as threatening. The project has worked with leaders at inception phase and has developed strategies throughout the project to mitigate risks for animators, diffuse tensions between leaders and animators, and strengthen their collaboration. This component has been key and will have to be strengthened, particularly in areas where Chukua Hatua was not pre-existing. Similarly, during the project lifespan, civic spaces in Tanzania have shrunk and control over online spaces has been strong according to analysts and researchers. Risk mitigation, offline and online, is a critical component to carry forward. 
Appendix 1: Summary statistics at baseline

The tables below show summary statistics for the animator sample (Table A1.1) and for the citizen sample (Table A1.2). Averages in the intervention and comparison groups are presented, and the significance of the difference between the two groups is tested.

Table A1.1 Balance checks, animators' sample

\begin{tabular}{|c|c|}
\hline $\begin{array}{c}\text { Comparison } \\
\text { mean }\end{array}$ & $\begin{array}{l}\text { Intervention } \\
\text { mean }\end{array}$ \\
\hline
\end{tabular}

\begin{tabular}{|c|c|c|c|c|c|}
\hline \multicolumn{6}{|c|}{ Animator characteristics - Demographics and Livelihood } \\
\hline Animator age & 39.400 & 33.561 & 0.040 & 71 & ** \\
\hline Animator is a woman & 0.433 & 0.537 & 0.397 & 71 & \\
\hline Animator knows how to read and write & 0.933 & 0.976 & 0.389 & 71 & \\
\hline Animator completed primary education & 0.267 & 0.512 & 0.038 & 71 & ** \\
\hline Animator's main activity is farming & 0.433 & 0.537 & 0.397 & 71 & \\
\hline Animator was a teacher & 0.067 & 0.000 & 0.096 & 71 & * \\
\hline Married or partnership & 0.833 & 0.610 & 0.042 & 71 & ** \\
\hline Single & 0.067 & 0.171 & 0.198 & 71 & \\
\hline Widowed & 0.100 & 0.049 & 0.412 & 71 & \\
\hline Separated/divorced & 0.000 & 0.171 & 0.017 & 71 & ** \\
\hline \multicolumn{6}{|l|}{ Household characteristics } \\
\hline Household size (winsorized) & 6.700 & 6.146 & 0.432 & 71 & \\
\hline Household head (share) & 0.633 & 0.512 & 0.316 & 71 & \\
\hline $\begin{array}{l}\text { Spouse } \\
\text { Asset ownership of the animator's household }\end{array}$ & 0.333 & 0.220 & 0.291 & 71 & \\
\hline Generator & 0.034 & 0.026 & 0.834 & 68 & \\
\hline Solar panel & 0.414 & 0.564 & 0.226 & 68 & \\
\hline Smartphone & 0.276 & 0.615 & 0.005 & 68 & *** \\
\hline Radio & 0.621 & 0.744 & 0.285 & 68 & \\
\hline Television & 0.207 & 0.231 & 0.818 & 68 & \\
\hline Mobile phone & 1.000 & 0.949 & 0.222 & 68 & \\
\hline Computer & 0.034 & 0.051 & 0.743 & 68 & \\
\hline Bicycle & 0.345 & 0.513 & 0.173 & 68 & \\
\hline Animal-drawn cart & 0.034 & 0.128 & 0.183 & 68 & \\
\hline Motorbike & 0.138 & 0.179 & 0.651 & 68 & \\
\hline Boat with a motor & 0.000 & 0.026 & 0.393 & 68 & \\
\hline $\begin{array}{l}\text { Agricultural land } \\
\text { Farm animals (cows, bulls, other cattle, } \\
\text { horses, donkeys, mules, goats, sheep, } \\
\text { chickens, or other poultry) }\end{array}$ & 0.517 & 0.872 & 0.001 & 68 & *** \\
\hline \multicolumn{6}{|l|}{ Status and involvement in the community } \\
\hline Participation in any group (share) & 0.724 & 0.692 & 0.780 & 68 & \\
\hline $\begin{array}{l}\text { Number of groups the respondent participated } \\
\text { in }\end{array}$ & 1.103 & 1.154 & 0.854 & 68 & \\
\hline Participation in livestock rearers' group & 0.138 & 0.179 & 0.651 & 68 & \\
\hline Participation in cooperatives or farmers' group & 0.138 & 0.256 & 0.238 & 68 & \\
\hline Participation in political group & 0.069 & 0.077 & 0.903 & 68 & \\
\hline
\end{tabular}

Governance and Accountability through Digitalization in Tanzania Impact Evaluation 2017-2019 
Table A1.1 Continued. Balance checks, animators' sample

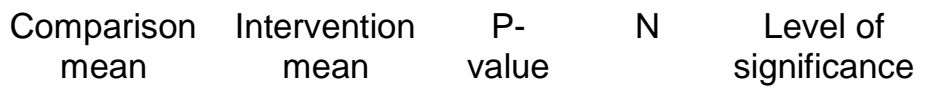

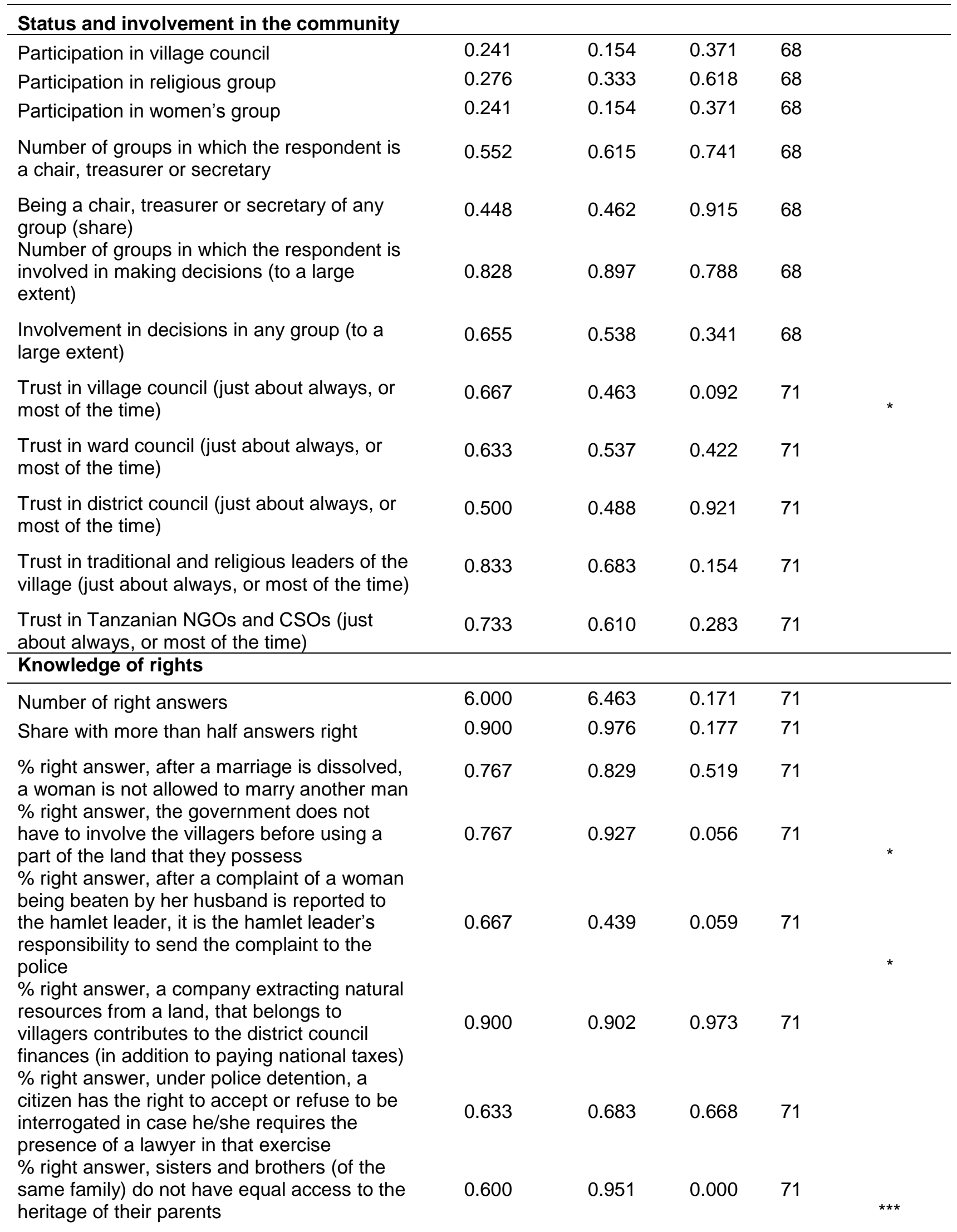


Table A1.1 Continued. Balance checks, animators' sample

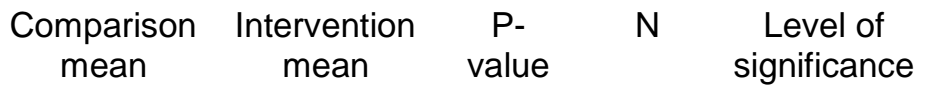

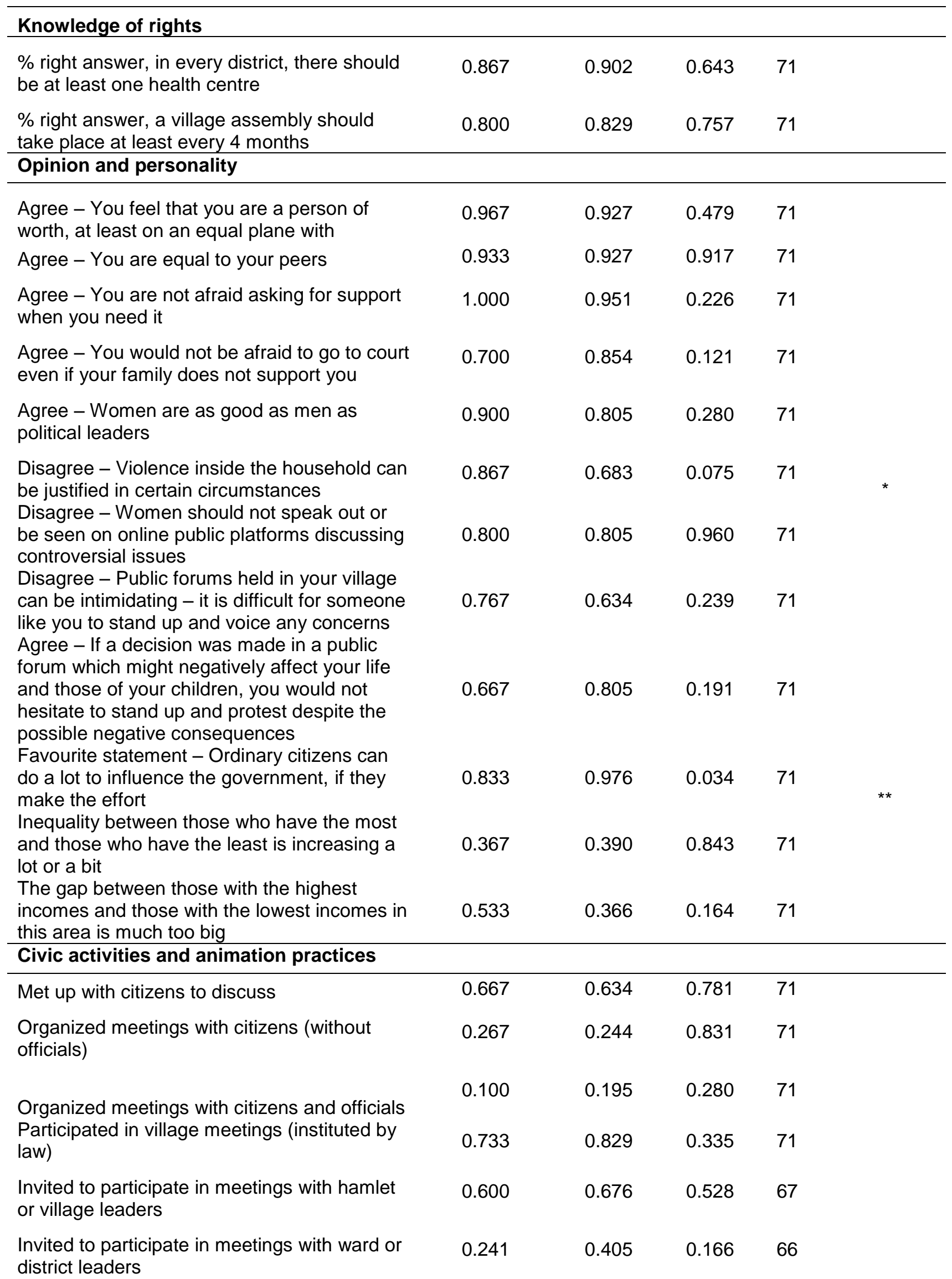

Governance and Accountability through Digitalization in Tanzania Impact Evaluation 2017-2019 
Table A1.1 Continued. Balance checks, animators' sample

\begin{tabular}{|c|c|c|}
\hline $\begin{array}{c}\text { Comparison } \\
\text { mean }\end{array}$ & $\begin{array}{l}\text { Intervention } \\
\text { mean }\end{array}$ & $\begin{array}{l}\mathrm{P}- \\
\text { value }\end{array}$ \\
\hline
\end{tabular}

\begin{tabular}{|c|c|c|c|c|c|}
\hline \multicolumn{6}{|l|}{ Civic activities and animation practices } \\
\hline $\begin{array}{l}\text { Educated and shared your skills and } \\
\text { experiences with others }\end{array}$ & 0.800 & 0.634 & 0.134 & 71 & \\
\hline $\begin{array}{l}\text { Energized people to act with you and join } \\
\text { action }\end{array}$ & 0.833 & 0.756 & 0.438 & 71 & \\
\hline $\begin{array}{l}\text { Sent out a message to elicit a speedy and } \\
\text { organized response }\end{array}$ & 0.333 & 0.634 & 0.012 & 71 & ** \\
\hline $\begin{array}{l}\text { Checked in with other animators or activists } \\
\text { regularly }\end{array}$ & 0.733 & 0.707 & 0.813 & 71 & \\
\hline Updated each other in cases of emergency & 0.500 & 0.707 & 0.077 & 71 & * \\
\hline $\begin{array}{l}\text { Reported any issues to the hamlet or village } \\
\text { leaders }\end{array}$ & 0.467 & 0.537 & 0.567 & 71 & \\
\hline $\begin{array}{l}\text { Reported any issues to the ward or district } \\
\text { leaders }\end{array}$ & 0.067 & 0.195 & 0.128 & 71 & \\
\hline Reported any issues to journalists & 0.033 & 0.073 & 0.479 & 71 & \\
\hline Reported any issues to CSO & 0.067 & 0.268 & 0.030 & 71 & ** \\
\hline $\begin{array}{l}\text { Does not feel very isolated conducting } \\
\text { animation activities }\end{array}$ & 0.700 & 0.707 & 0.948 & 71 & \\
\hline $\begin{array}{l}\text { Discussed issues related to rights or access to } \\
\text { services with other animator(s) }\end{array}$ & 0.600 & 0.683 & 0.477 & 71 & \\
\hline $\begin{array}{l}\text { Discussed issues related to rights or access to } \\
\text { services with other animator(s) }\end{array}$ & 0.300 & 0.585 & 0.017 & 71 & ** \\
\hline $\begin{array}{l}\text { Received any information from an external } \\
\text { source that helped you raised awareness }\end{array}$ & 0.267 & 0.537 & 0.023 & 71 & ** \\
\hline $\begin{array}{l}\text { Received other external support } \\
\text { Willing to keep organizing activities/facilitating }\end{array}$ & 0.067 & 0.317 & 0.010 & 71 & ** \\
\hline $\begin{array}{l}\text { discussions around rights and access to social } \\
\text { services in the village }\end{array}$ & 0.967 & 0.951 & 0.753 & 71 & \\
\hline $\begin{array}{l}\text { Money identified as a challenge moving } \\
\text { forward }\end{array}$ & 0.533 & 0.415 & 0.329 & 71 & \\
\hline $\begin{array}{l}\text { Power (even though I raise my voice, it is not } \\
\text { heard) }\end{array}$ & 0.133 & 0.073 & 0.408 & 71 & \\
\hline Lack of responses from local government & 0.200 & 0.390 & 0.089 & 71 & * \\
\hline Lack of interest from citizens & 0.100 & 0.098 & 0.973 & 71 & \\
\hline \multicolumn{6}{|l|}{ Digital use } \\
\hline Owned (personally) a mobile phone & 0.933 & 0.854 & 0.301 & 71 & \\
\hline Owned (personally) a smartphone & 0.233 & 0.488 & 0.029 & 71 & ** \\
\hline Owned or had regular access to a smartphone & 0.233 & 0.512 & 0.017 & 71 & ** \\
\hline Has used a computer & 0.033 & 0.146 & 0.118 & 71 & \\
\hline Has used a smartphone & 0.233 & 0.512 & 0.017 & 71 & ** \\
\hline Read newspaper at least once a week & 0.133 & 0.341 & 0.047 & 71 & ** \\
\hline Watched TV at least once a week & 0.433 & 0.488 & 0.655 & 71 & \\
\hline Listened to the radio at least once a week & 0.833 & 0.659 & 0.103 & 71 & \\
\hline Observations & 30 & 41 & & & \\
\hline
\end{tabular}


Table A1.2 Balance checks, citizens' sample

Comparison Intervention $P$-value

mean mean

Level of significance

\begin{tabular}{|c|c|c|c|c|c|}
\hline \multicolumn{6}{|l|}{$\begin{array}{l}\text { Citizen characteristics - Demographics } \\
\text { and Livelihood }\end{array}$} \\
\hline Citizen age & 38.872 & 37.195 & 0.257 & 901 & \\
\hline Citizen is a woman & 0.533 & 0.481 & 0.052 & 901 & * \\
\hline Citizen knows how to read and write & 0.561 & 0.701 & 0.089 & 901 & * \\
\hline Citizen completed primary education & 0.146 & 0.176 & 0.455 & 901 & \\
\hline Citizen's main activity is farming & 0.467 & 0.579 & 0.379 & 901 & \\
\hline Citizen from Arusha & 0.345 & 0.303 & 0.825 & 901 & \\
\hline Citizen from Kigoma & 0.000 & 0.151 & 0.077 & 901 & * \\
\hline Citizen from Geita & 0.313 & 0.257 & 0.741 & 901 & \\
\hline Citizen from Lindi/Mtwara & 0.342 & 0.290 & 0.765 & 901 & \\
\hline Married or partnership & 0.747 & 0.739 & 0.854 & 901 & \\
\hline Single & 0.107 & 0.160 & 0.145 & 901 & \\
\hline Widowed & 0.070 & 0.048 & 0.100 & 901 & \\
\hline Separated/divorced & 0.076 & 0.052 & 0.364 & 901 & \\
\hline \multicolumn{6}{|l|}{ Household characteristics } \\
\hline Household size (winsorized) & 5.880 & 6.263 & 0.448 & 901 & \\
\hline Household head (share) & 0.530 & 0.485 & 0.087 & 901 & * \\
\hline Spouse & 0.350 & 0.322 & 0.325 & 901 & \\
\hline Child & 0.070 & 0.093 & 0.312 & 901 & \\
\hline Father/mother & 0.039 & 0.060 & 0.172 & 901 & \\
\hline Other & 0.010 & 0.041 & 0.013 & 901 & ** \\
\hline \multicolumn{6}{|l|}{$\begin{array}{l}\text { Asset ownership of the citizen's household } \\
\text { (share owning) }\end{array}$} \\
\hline Generator & 0.030 & 0.028 & 0.914 & 866 & \\
\hline Solar panel & 0.285 & 0.315 & 0.565 & 866 & \\
\hline Smartphone & 0.090 & 0.122 & 0.240 & 866 & \\
\hline Radio & 0.495 & 0.594 & 0.181 & 866 & \\
\hline Television & 0.160 & 0.127 & 0.449 & 866 & \\
\hline Mobile phone & 0.739 & 0.775 & 0.431 & 866 & \\
\hline Computer & 0.014 & 0.026 & 0.253 & 866 & \\
\hline Bicycle & 0.391 & 0.516 & 0.292 & 866 & \\
\hline Animal drawn cart & 0.014 & 0.036 & 0.301 & 866 & \\
\hline Motorbike & 0.095 & 0.124 & 0.351 & 866 & \\
\hline Boat with a motor & 0.003 & 0.008 & 0.325 & 866 & \\
\hline Agricultural land & 0.508 & 0.785 & 0.039 & 866 & ** \\
\hline $\begin{array}{l}\text { Farm animals (cows, bulls, other } \\
\text { cattle, horses, donkeys, mules, goats, } \\
\text { sheep, chickens, or other poultry) }\end{array}$ & 0.693 & 0.691 & 0.978 & 866 & \\
\hline $\begin{array}{l}\mathrm{HH} \text { in the first } 20 \% \text { of the asset-based } \\
\text { wealth distribution }\end{array}$ & 0.315 & 0.141 & 0.053 & 866 & * \\
\hline $\begin{array}{l}\mathrm{HH} \text { in the second } 20 \% \text { of the asset-based } \\
\text { wealth distribution }\end{array}$ & 0.188 & 0.235 & 0.175 & 866 & \\
\hline $\begin{array}{l}\mathrm{HH} \text { in the third } 20 \% \text { of the asset-based } \\
\text { wealth distribution }\end{array}$ & 0.207 & 0.255 & 0.328 & 866 & \\
\hline $\begin{array}{l}\mathrm{HH} \text { in the fourth } 20 \% \text { of the asset-based } \\
\text { wealth distribution }\end{array}$ & 0.130 & 0.165 & 0.432 & 866 & \\
\hline
\end{tabular}


Table A1.2 Continued. Balance checks, citizens' sample

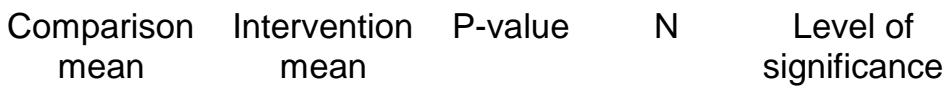

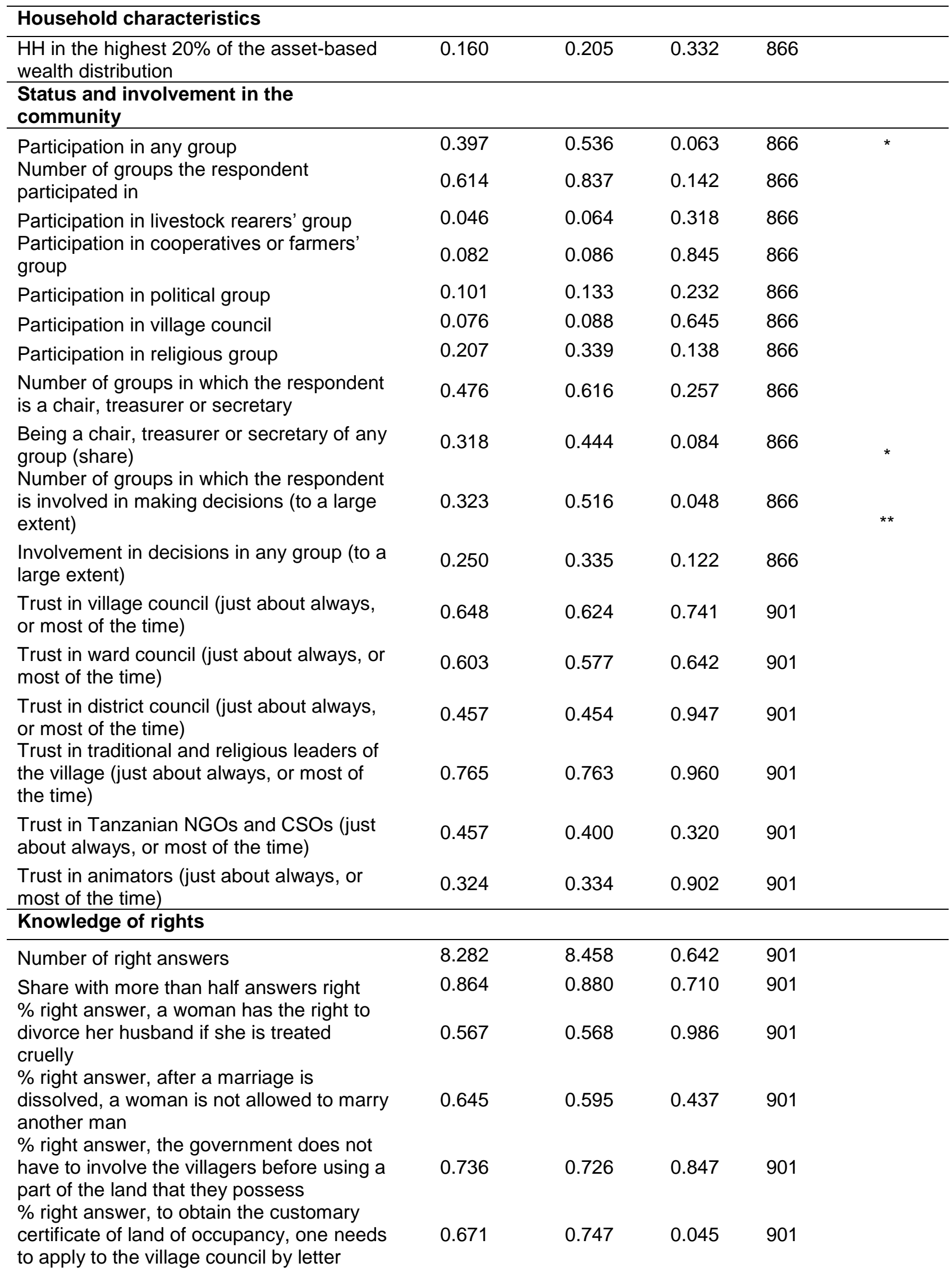


Table A1.2 Continued. Balance checks, citizens' sample

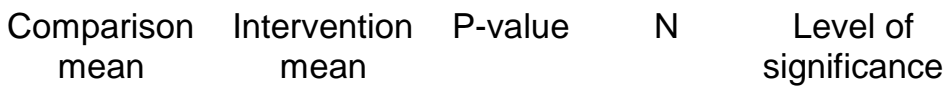

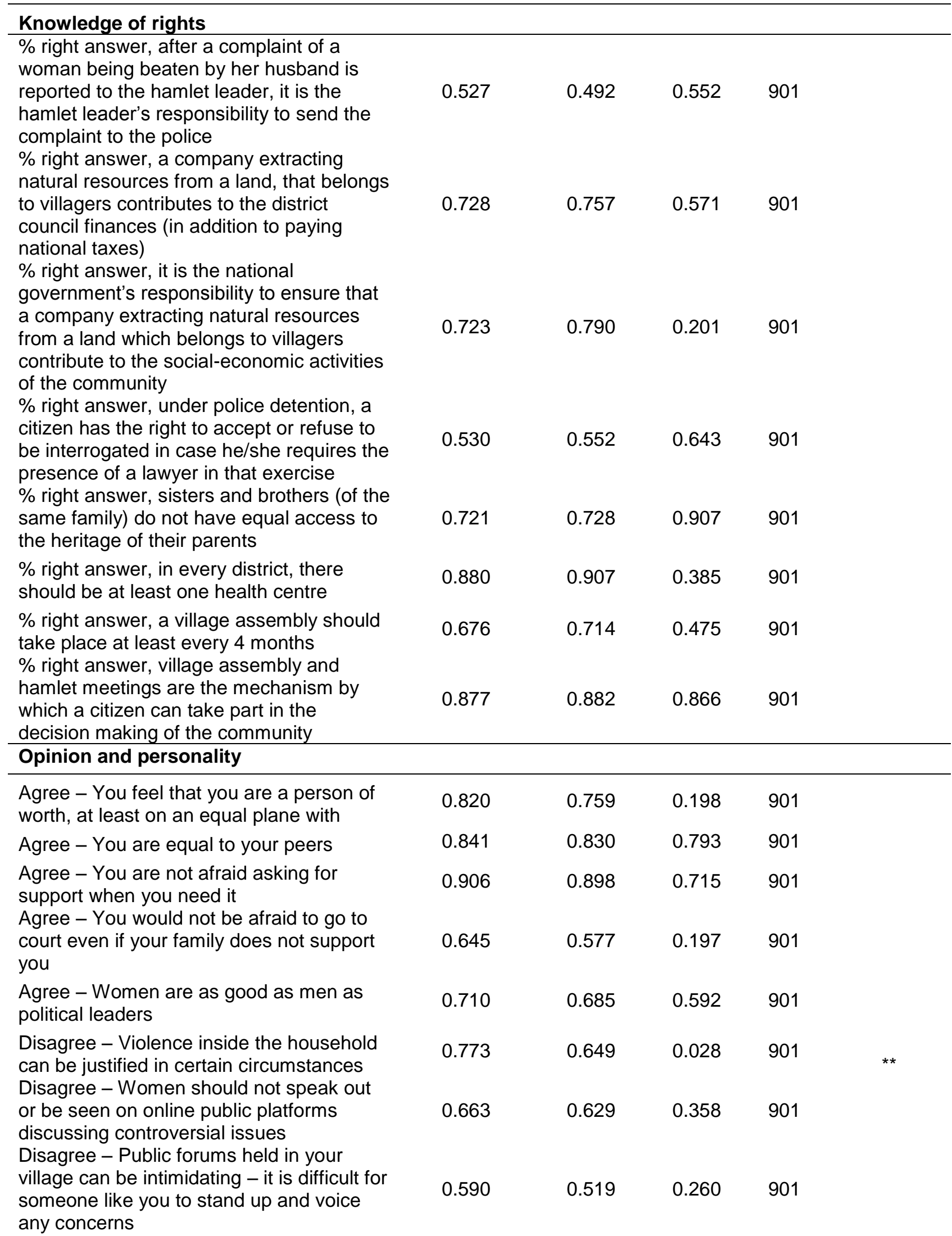


Table A1.2 Continued. Balance checks, citizens' sample

Comparison Intervention P-value $\mathrm{N}$ mean mean

Level of significance

\section{Opinion and personality}

Agree - If a decision was made in a public forum which might negatively affect your

life and those of your children, you would not hesitate to stand up and protest

0.527

0.490

0.488

901

despite the possible negative

consequences

Favourite statement - Ordinary citizens

can do a lot to influence the government, if

they make the effort

Inequality between those who have the

most and those who have the least is

0.801

0.337

901

increasing a lot or a bit

$\begin{array}{llll}0.480 & 0.560 & 0.267 & 901\end{array}$

The gap between those with the highest

incomes and those with the lowest

0.407

0.481

$0.142 \quad 901$

incomes in this area is much too big

\section{Civic activities}

Participated in meetings with citizens

(without any village leaders/officials)

0.141

0.135

0.883

901

Invited to participate in meetings organized

by the village animator(s) (without any

0.104

0.149

0.417

901

village leaders/officials)

Average number of participation in

meetings organized by the village

animator(s) (without any village

3.125

2.597

0.269

117

leaders/officials)

Met up with (one of) the village

animator(s), for individual conversations

around their rights and access to services

Know any person playing the role of

animator in your village

Invited to participate in meeting with

citizens and officials (community dialogues

or lobby meetings)

Village meetings (instituted by law) took

place every 3 months or more often

$\begin{array}{llll}0.076 & 0.114 & 0.307 & 901\end{array}$

Participated in village meetings (instituted by law)

$\begin{array}{llll}0.167 & 0.216 & 0.371 & 901\end{array}$

Average number of participation in village meetings

Reported any issues to the hamlet, village, ward OR district leaders

$\begin{array}{llll}0.287 & 0.324 & 0.332 & 901\end{array}$

Reported any issues to journalists

\section{Digital use}

Owned (personally) a mobile phone

$\begin{array}{llll}0.825 & 0.832 & 0.853 & 901\end{array}$

Owned (personally) a smartphone

$\begin{array}{llll}0.760 & 0.737 & 0.588 & 901\end{array}$

Has used a computer

$\begin{array}{llll}2.612 & 2.556 & 0.895 & 802\end{array}$

Has used a smartphone

$\begin{array}{llll}0.214 & 0.253 & 0.235 & 901\end{array}$

Read newspaper at least once a week

0.010

0.010

0.901

901

Watched TV at least once a week

0.496

0.523

0.641

901

0.060

0.089

0.232

901

0.016

0.037

0.096

901

0.076

0.114

0.185

901

0.131

0.151

0.593

901

Listened to the radio at least once a week

0.363

0.315

0.413

901

0.535

0.597

0.305

901 
Table A1.2 Continued. Balance checks, citizens' sample

\begin{tabular}{|c|c|c|c|}
\hline $\begin{array}{c}\text { Comparison } \\
\text { mean }\end{array}$ & $\begin{array}{l}\text { Intervention } \\
\text { mean }\end{array}$ & P-value & $\mathrm{N}$ \\
\hline
\end{tabular}

\section{Digital use}

Felt comfortable to a small or very small extent with village animator using a

smartphone

0.172

0.348

0.049

176

Observations

$383 \quad 518$

Note: Standard errors are clustered at the village level; ${ }^{* * *} \mathrm{p}<0.01,{ }^{* *} \mathrm{p}<0.05,{ }^{*} \mathrm{p}<0.1$. 


\section{APPENDIX 2: KNOWLEDGE OF RIGHTS}

At baseline and endline, the survey included a module in which citizens were asked to identify whether a statement about their rights was true or false. This appendix presents the statements used in both modules.

\section{Table A2.1 Baseline module}

\begin{tabular}{|c|c|}
\hline & Correct answers \\
\hline \multicolumn{2}{|l|}{ Rights to divorce } \\
\hline $\begin{array}{l}\text { According to the national law, a woman has the right to divorce her } \\
\text { husband if she is treated cruelly. }\end{array}$ & TRUE \\
\hline $\begin{array}{l}\text { According to the national law, after a marriage is dissolved, a woman is } \\
\text { not allowed to marry another man. }\end{array}$ & FALSE \\
\hline \multicolumn{2}{|l|}{ Land rights } \\
\hline $\begin{array}{l}\text { According to the national law, the government does not have to involve } \\
\text { the villagers before using a part of the land that they possess. }\end{array}$ & FALSE \\
\hline $\begin{array}{l}\text { According to the national law, to obtain the customary certificate of land } \\
\text { of occupancy, one needs to apply to the village council by letter. }\end{array}$ & TRUE \\
\hline \multicolumn{2}{|l|}{ Gender-based violence } \\
\hline $\begin{array}{l}\text { According to the national law, after a complaint of a woman being } \\
\text { beaten by her husband is reported to the hamlet leader, it is the hamlet } \\
\text { leader's responsibility to send the complaint to the police. }\end{array}$ & TRUE \\
\hline \multicolumn{2}{|l|}{ Natural resources } \\
\hline $\begin{array}{l}\text { According to the national law, a company extracting natural resources } \\
\text { from a land that belongs to villagers contributes to the district council } \\
\text { finances (in addition to paying national taxes). }\end{array}$ & TRUE \\
\hline $\begin{array}{l}\text { According to the national law, it is the national government's } \\
\text { responsibility to ensure that a company extracting natural resources } \\
\text { from a land which belongs to villagers contribute to the social-economic } \\
\text { activities of the community. }\end{array}$ & TRUE \\
\hline \multicolumn{2}{|l|}{ Rights vis-à-vis the police } \\
\hline $\begin{array}{l}\text { According to the national law, under police detention, a citizen has the } \\
\text { right to accept or refuse to be interrogated in case he/she requires the } \\
\text { presence of a lawyer in that exercise. }\end{array}$ & TRUE \\
\hline \multicolumn{2}{|l|}{ Rights to inheritance } \\
\hline $\begin{array}{l}\text { According to the national law, sisters and brothers (of the same family) } \\
\text { do not have equal access to the heritage of their parents. }\end{array}$ & FALSE \\
\hline \multicolumn{2}{|l|}{ Access to health services } \\
\hline $\begin{array}{l}\text { According to the health policy, in every district, there should be at least } \\
\text { one health centre. }\end{array}$ & TRUE \\
\hline \multicolumn{2}{|l|}{ Rights to participate in community decision making } \\
\hline $\begin{array}{l}\text { According to the national law, a village assembly should take place at } \\
\text { least every } 4 \text { months. }\end{array}$ & FALSE \\
\hline $\begin{array}{l}\text { Village assembly and hamlet meetings are the mechanism by which a } \\
\text { citizen can take part in the decision making of the community. }\end{array}$ & TRUE \\
\hline
\end{tabular}


Table A2.2 Endline module

\begin{tabular}{|c|c|}
\hline & Correct answers \\
\hline \multicolumn{2}{|l|}{ Early marriage } \\
\hline According to the national law, girls under 18 can marry. & FALSE \\
\hline \multicolumn{2}{|l|}{ Rights to education } \\
\hline According to the law, completing primary education is compulsory. & TRUE \\
\hline $\begin{array}{l}\text { According to the national law, parents could face prison if their child } \\
\text { drops-out from school because of them. }\end{array}$ & TRUE \\
\hline \multicolumn{2}{|l|}{ Natural resources exploitation } \\
\hline $\begin{array}{l}\text { According to the national law, Local Government Authorities are not } \\
\text { entitled to a share of the annual sales of a company extracting natural } \\
\text { resources from the land. }\end{array}$ & FALSE \\
\hline \multicolumn{2}{|l|}{ Children's rights } \\
\hline $\begin{array}{l}\text { According to the national law, for children below } 18 \text {, child labour is } \\
\text { forbidden. }\end{array}$ & TRUE \\
\hline \multicolumn{2}{|l|}{ Female Genitalia Mutilation } \\
\hline According to the national law, Female Genitalia Mutilation is legal. & FALSE \\
\hline $\begin{array}{l}\text { According to the national law, someone performing Female Genitalia } \\
\text { Mutilation on someone under } 18 \text { is committing an offence of cruelty to } \\
\text { children. }\end{array}$ & TRUE \\
\hline \multicolumn{2}{|l|}{ Process to claim rights } \\
\hline $\begin{array}{l}\text { As a citizen, if your rights regarding access to social services are not } \\
\text { respected and you communicated it to the hamlet chair person, it is her } \\
\text { or his responsibility to bring it up at the ward level. }\end{array}$ & TRUE \\
\hline \multicolumn{2}{|l|}{$\begin{array}{l}\text { Rights to participate in community decision making (same as } \\
\text { baseline) }\end{array}$} \\
\hline $\begin{array}{l}\text { According to the national law, a village assembly should take place at } \\
\text { least every } 4 \text { months. }\end{array}$ & FALSE \\
\hline $\begin{array}{l}\text { Village assembly and hamlet meetings are the mechanism by which a } \\
\text { citizen can take part in the decision making of the community. }\end{array}$ & TRUE \\
\hline
\end{tabular}




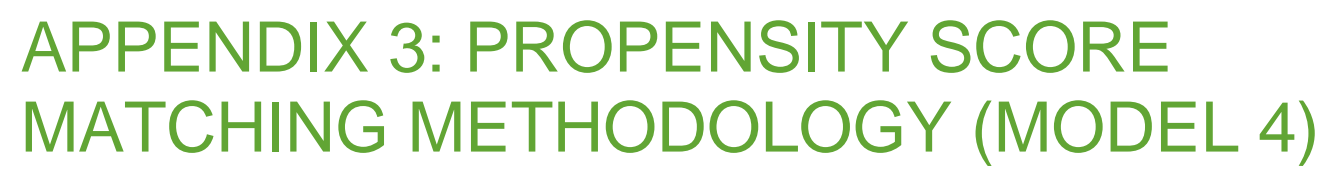

The analysis of outcome variables presented in Section 4.1 of this report involved group mean comparisons using propensity-score matching (PSM) when the outcome variable was not measured at baseline. The basic principle of PSM is to match each citizen living in project areas with a citizen leaving in a comparison area that was observationally similar at baseline and to obtain the project treatment effect by averaging the differences in outcomes across the two groups after project completion. Unsurprisingly, there are different approaches to matching, i.e. to determining whether or not an individual is observationally 'similar' to another individual. For an overview, we refer to Caliendo and Kopeinig (2008).

The following sections describe and test the specific matching procedures followed for some analyses in this impact evaluation.

\section{Estimating propensity scores}

Given that it is extremely hard to find two individuals with exactly the same characteristics, Rosenbaum and Rubin (1983) demonstrate that it is possible to match individuals using a prior probability for an individual to be in the intervention group, naming this its propensity score. More specifically, propensity scores are obtained by pooling the units from both the intervention and comparison groups and using a statistical probability model (e.g. a probit regression) to estimate the probability of participating in the project, conditional on a set of observed characteristics.

Table A3.1 presents the probit regression results used to estimate the propensity scores in our context. To guarantee that none of the matching variables were affected by the intervention, we only considered variables that were measured at baseline, and only those variables that were unlikely to have been influenced by anticipation of project participation (Caliendo and Kopeinig, 2008).

Table A3.1: Estimating the propensity score on variables used for matching

\begin{tabular}{|c|c|c|c|}
\hline & $\begin{array}{c}\text { Marginal } \\
\text { effect }\end{array}$ & Standard error & p-value \\
\hline \multicolumn{4}{|l|}{ Being in the intervention group } \\
\hline Citizen age & $-0.01^{*}$ & 0.01 & 0.03 \\
\hline Citizen age squared & 0.00 & 0.00 & 0.06 \\
\hline Citizen is a woman & 0.03 & 0.04 & 0.48 \\
\hline Citizen knows how to read and write & $0.12^{*}$ & 0.05 & 0.02 \\
\hline Participation in any group & $0.11^{*}$ & 0.05 & 0.03 \\
\hline $\begin{array}{l}\text { Number of groups in which the respondent is involved in } \\
\text { making decisions (to a large extent) }\end{array}$ & 0.04 & 0.03 & 0.23 \\
\hline $\begin{array}{l}\text { Felt comfortable to a small or very small extent with village } \\
\text { animator using a smartphone }\end{array}$ & $0.23^{\star *}$ & 0.08 & 0.01 \\
\hline $\begin{array}{l}\mathrm{HH} \text { in the second } 20 \% \text { of the asset-based wealth } \\
\text { distribution }\end{array}$ & $0.20^{\star \star \star}$ & 0.06 & 0.00 \\
\hline $\mathrm{HH}$ in the third $20 \%$ of the asset-based wealth distribution & $0.20^{\star \star \star}$ & 0.06 & 0.00 \\
\hline $\mathrm{HH}$ in the fourth $20 \%$ of the asset-based wealth distribution & $0.15^{*}$ & 0.07 & 0.03 \\
\hline $\begin{array}{l}\mathrm{HH} \text { in the highest } 20 \% \text { of the asset-based wealth } \\
\text { distribution }\end{array}$ & $0.16^{*}$ & 0.07 & 0.01 \\
\hline Household size (winsorized) & $0.01^{*}$ & 0.01 & 0.02 \\
\hline Know any person playing the role of animator in your village & -0.00 & 0.06 & 0.96 \\
\hline Participated in village meeting (instituted by law) & -0.06 & 0.05 & 0.18 \\
\hline Citizen from Arusha & -0.02 & 0.06 & 0.73 \\
\hline Citizen from Geita & $-0.23^{\star \star \star}$ & 0.05 & 0.00 \\
\hline Observations & 669 & & \\
\hline
\end{tabular}


The construction of the wealth index is described in Section 5. Variables dated 2009 are estimates, based on recall data.

Dependent variable is binary, taking 1 for project participant households, and 0 otherwise.

${ }^{*} p<0.1,{ }^{* *} p<0.05,{ }^{* * *} p<0.01$.

\section{Defining the region of common support}

After estimating the propensity scores, the presence of a good common support area needs to be checked. The area of common support is the region where the propensityscore distributions of the treatment and comparison groups overlap. The common support assumption ensures that 'treatment observations have a comparison observation 'nearby' in the propensity score distribution' (Heckman, LaLonde and Smith, 1999). Since some significant differences were found between the intervention and comparison groups in terms of the baseline and demographic characteristics (as detailed in Section 3.2.4), some of the citizens in the intervention group are too different from the comparison group to allow for meaningful comparison. We developed a minima and maxima comparison, deleting all observations whose propensity score was smaller than the minimum and larger than the maximum in the opposite group (Caliendo and Kopeinig, 2008). In this particular case, nine of the $669^{31}$ citizens surveyed - all nine being in the comparison villages - were dropped because they lay outside the common support area. This means that the estimates of differences in outcome characteristics between the two groups apply to this subsample of project participants and nonparticipants; that is, they do represent the surveyed population as a whole (less than 2 percent of observations fell out of the common support).

Figure A3.1 illustrates the area of common support and indicates the proportion of households lying on and off the common support area, by treatment group.

\section{Figure A3.1: Propensity score on and off common support}

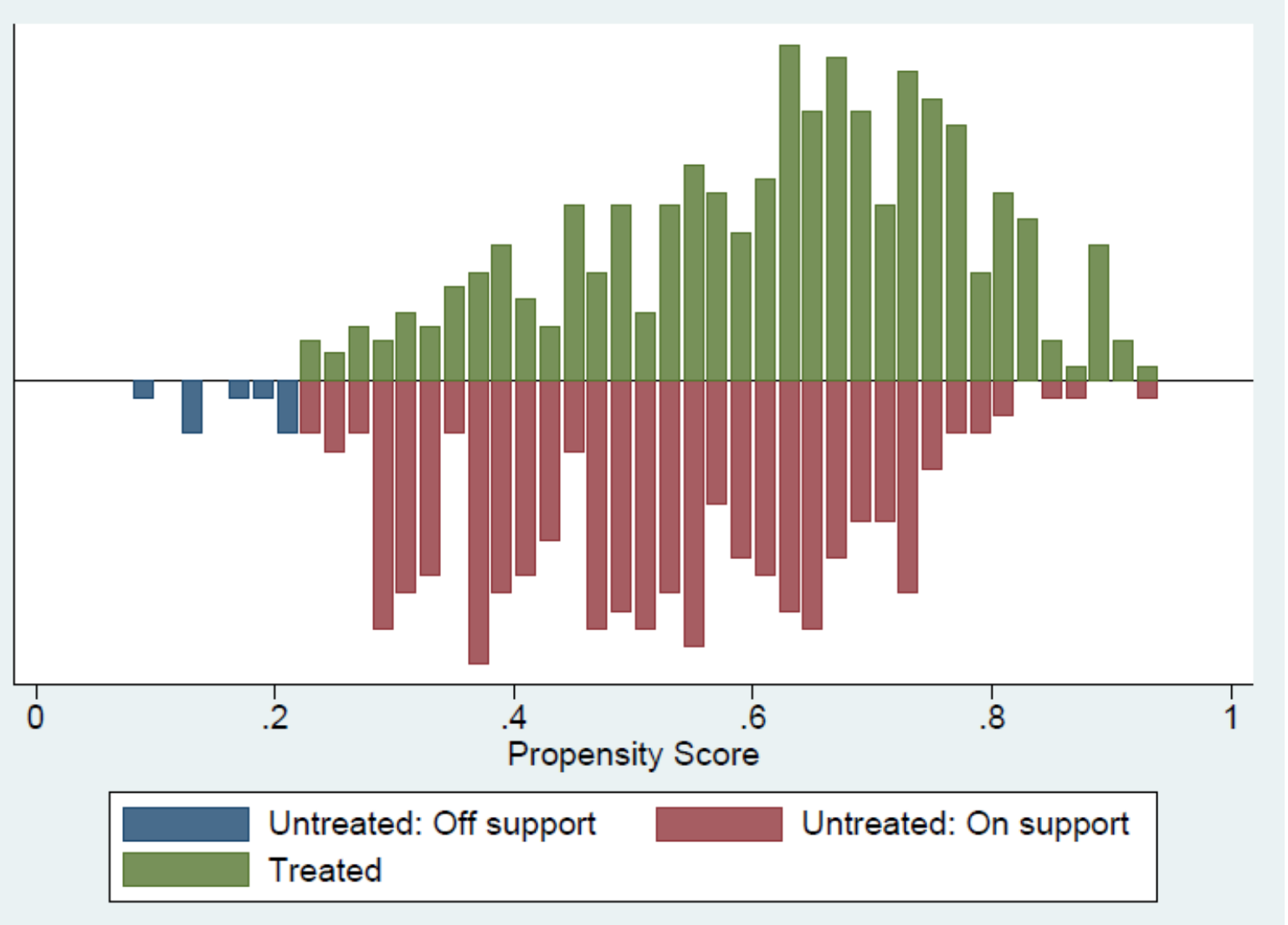




\section{Matching intervention households to comparison households}

Following Rosenbaum and Rubin (1983), after estimating the propensity scores and defining the area of common support, individuals are matched on the basis of their propensity score. The literature has developed a variety of matching procedures. For the main results presented in this report using a matching model, we chose to employ the method of kernel matching. The kernel matching method weights the contribution of each comparison group member, attaching greater weight to those comparison observations that provide a better match with the treatment observations. One common approach is to use the normal distribution with mean zero as a kernel, and weights given by the distribution of the differences in propensity score. Thus 'good' matches get a larger weight than 'poor' matches.

We used the psmatch2 module in STATA using 0.06 as a bandwidth and restricted the analysis on the area of common support. When using PSM, standard errors of the estimates were bootstrapped using 1,000 repetitions to account for the additional variation caused by the estimation of the propensity scores and the determination of the common support. ${ }^{32}$

For PSM to be valid, the intervention group and the matched comparison group need to be balanced in that they need to be similar in terms of their observed baseline characteristics. This should be checked. The most straightforward method of doing this is to test whether there are any statistically significant differences in baseline covariates between the intervention and comparison groups in the matched sample. The balance of each of the matching variables after kernel matching is shown in Table A3.2 (the estimates are provided using PS weighted regressions, clustering at the village level). None of the variables implemented for the matching is statistically significant once the matched sample is used.

Table A3.2: Balancing test on the set of covariates used for matching, after matching

\begin{tabular}{|c|c|c|c|}
\hline & $\begin{array}{l}\text { Intervention } \\
\text { group mean }\end{array}$ & $\begin{array}{l}\text { Comparison } \\
\text { group mean }\end{array}$ & $p$-value \\
\hline Citizen is a woman & 0.5 & 0.52 & 0.6 \\
\hline Citizen age & 38.18 & 39.05 & 0.66 \\
\hline Citizen age squared & 1701.82 & 1776.5 & 0.66 \\
\hline Citizen knows how to read and write & 0.72 & 0.72 & 1 \\
\hline Participation in any group & 0.57 & 0.57 & 0.89 \\
\hline $\begin{array}{l}\text { Number of groups in which the } \\
\text { respondent is involved in making } \\
\text { decisions (to a large extent) }\end{array}$ & 0.57 & 0.56 & 0.99 \\
\hline $\begin{array}{l}\text { Felt comfortable to a small or very } \\
\text { small extent with village animator } \\
\text { using a smartphone }\end{array}$ & 0.07 & 0.06 & 0.65 \\
\hline $\begin{array}{l}\mathrm{HH} \text { in the second } 20 \% \text { of the asset- } \\
\text { based wealth distribution }\end{array}$ & 0.24 & 0.23 & 0.89 \\
\hline $\begin{array}{l}\mathrm{HH} \text { in the third } 20 \% \text { of the asset- } \\
\text { based wealth distribution }\end{array}$ & 0.25 & 0.26 & 0.95 \\
\hline $\begin{array}{l}\mathrm{HH} \text { in the fourth } 20 \% \text { of the asset- } \\
\text { based wealth distribution }\end{array}$ & 0.17 & 0.16 & 0.87 \\
\hline $\begin{array}{l}\mathrm{HH} \text { in the highest } 20 \% \text { of the asset- } \\
\text { based wealth distribution }\end{array}$ & 0.2 & 0.2 & 0.96 \\
\hline Household size (winsorized) & 6.34 & 6.32 & 0.97 \\
\hline
\end{tabular}

Governance and Accountability through Digitalization in Tanzania Impact Evaluation 2017-2019 
Table A3.2 Continued: Balancing test on the set of covariates used for matching, after matching

\begin{tabular}{lccc}
\hline & $\begin{array}{c}\text { Intervention } \\
\text { group mean }\end{array}$ & $\begin{array}{c}\text { Comparison } \\
\text { group mean }\end{array}$ & p-value \\
\hline $\begin{array}{l}\text { Know any person playing the role of } \\
\text { animator in your village }\end{array}$ & 0.22 & 0.2 & 0.71 \\
$\begin{array}{l}\text { Participated in village meetings } \\
\text { (instituted by law) }\end{array}$ & 0.73 & 0.71 & 0.59 \\
Citizen from Arusha & 0.28 & 0.27 & 0.98 \\
Citizen from Geita & 0.26 & 0.25 & 0.93 \\
\hline Observations & 660 & & \\
\hline
\end{tabular}

The matching process reduces the differences between the two groups. Among 72 variables, seven are statistically significantly different after the matching process, and these seven variables are presented in Table A3.3. 
Table A3.3: Balancing test on other baseline characteristics, after matching

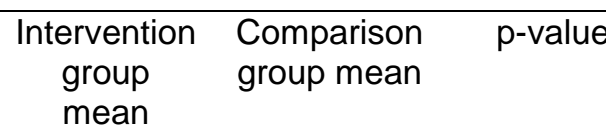

Other relationship to the head than head, spouse, child, parent

0.03

0.01

0.06

The HH owned a mobile phone

0.78

0.87

0.01

The $\mathrm{HH}$ owned an animal drawn cart

0.03

0.01

0.06

Trust in Tanzanian NGOs and CSOs - just about always, or most of the time -

0.41

0.51

0.09

Disagree - Violence inside the household can be justified in certain circumstances

Agree - If a decision was made in a public forum which might negatively affect your life and those of your children, you would not hesitate to stand up and protest despite the possible negative consequences 


\section{APPENDIX 4: MULTIDIMENSIONAL INDICES OF 'POWER WITHIN' AND 'POWER TO'}

Based on literature review and understanding of the setting in which the project takes place, we identified characteristics associated with 'power within' and 'power to', presented in the table below. Each characteristic was then transformed into a dummy indicator (see the column 'definition' in the table below). We then aggregated all indicators in an index: the number of indicators in which each citizen reaches the threshold was counted, and the total is divided by the number of indicators. The resulting ratio - the proportion of indicators in which each citizen scored above the threshold - is defined as the index for each sense of power.

This approach is similar to the multidimensional measurement of women's empowerment (Lombardini et al., 2017) and resilience capacities, developed in Oxfam's Effectiveness Reviews, ${ }^{33}$ and inspired by the Alkire-Foster method used by the Oxford Poverty and Human Development Initiative. ${ }^{34}$

Table A4.1: Indicators of 'power within' and 'power to'

\begin{tabular}{|c|c|c|c|}
\hline & Dimension & Rationale & Definition \\
\hline \multirow{5}{*}{$\begin{array}{l}\frac{5}{c} \\
\frac{1}{3} \\
\frac{1}{3} \\
\frac{1}{0} \\
0\end{array}$} & $\begin{array}{l}\text { Knowledge of } \\
\text { rights and } \\
\text { responsibilities }\end{array}$ & $\begin{array}{l}\text { As a citizen, 'power within' is about the } \\
\text { realization that one has rights and } \\
\text { responsibilities and that those elected } \\
\text { should serve those who elected them. }\end{array}$ & $\begin{array}{l}\text { Citizen scores more than the median } \\
\text { share of right responses ( } 0.75 \text { at } \\
\text { baseline and endline). }\end{array}$ \\
\hline & $\begin{array}{l}\text { Belief in collective } \\
\text { action's } \\
\text { effectiveness }\end{array}$ & $\begin{array}{l}\text { Belief in collective action's effectiveness } \\
\text { is a sign of 'power within' being built, } \\
\text { and is needed for individuals to be able } \\
\text { to claim their rights. According to the } \\
\text { Powercube.net, "Power within" is the } \\
\text { capacity to imagine and have hope; it } \\
\text { affirms the common human search for } \\
\text { dignity and fulfilment.' }\end{array}$ & $\begin{array}{l}\text { Citizen picks 'Ordinary citizens can do a } \\
\text { lot to influence the government, if they } \\
\text { make the effort' over 'There is not much } \\
\text { that ordinary citizens can do to influence } \\
\text { the government'. }\end{array}$ \\
\hline & Self-confidence & $\begin{array}{l}\text { Self-confidence contributes to one's } \\
\text { inner sense of power. Following the } \\
\text { Powercube.net, "'Power within" has to } \\
\text { do with a person's sense of self-worth } \\
\text { and self-knowledge.' }\end{array}$ & $\begin{array}{l}\text { Citizen agrees with the statement 'You } \\
\text { feel that you are a person of worth, at } \\
\text { least on an equal plane with others' and } \\
\text { with the statement 'You are equal to } \\
\text { your peers (e.g. sisters, friends, } \\
\text { colleagues, etc.)'. }\end{array}$ \\
\hline & Self-esteem & $\begin{array}{l}\text { Self-esteem contributes to one's inner } \\
\text { sense of power. Following the } \\
\text { Powercube.net, "Power within" has to } \\
\text { do with a person's sense of self-worth } \\
\text { and self-knowledge.' }\end{array}$ & $\begin{array}{l}\text { Citizen agrees with the statement 'You } \\
\text { are not afraid of asking for support when } \\
\text { you need it' and 'You would not be } \\
\text { afraid to go to court even if your family } \\
\text { does not support you'. }\end{array}$ \\
\hline & $\begin{array}{l}\text { Gender role about } \\
\text { speaking up }\end{array}$ & $\begin{array}{l}\text { Perception of others' political role and } \\
\text { public behaviours contribute to one's } \\
\text { inner sense of power. For women in } \\
\text { particular, Lombardini et al. (2017) } \\
\text { highlight that '“Power within" is } \\
\text { described by indicators referring to how } \\
\text { a woman perceives herself and other } \\
\text { women in the society'. }\end{array}$ & $\begin{array}{l}\text { Citizen agrees with the statement } \\
\text { 'Women are as good as men as political } \\
\text { leaders' and disagrees with the } \\
\text { statement 'Women should not speak out } \\
\text { or be seen on online public platforms } \\
\text { discussing controversial issues } \\
\text { (Facebook, Twitter, Instagram, etc.)'. }\end{array}$ \\
\hline
\end{tabular}


Table A4.1 continued: Indicators of 'power within' and 'power to'

\begin{tabular}{|c|c|c|c|}
\hline & Dimension & Rationale & Definition \\
\hline \multirow{5}{*}{ 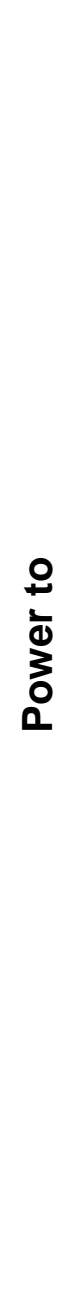 } & $\begin{array}{l}\text { Connection with } \\
\text { other citizens }\end{array}$ & $\begin{array}{l}\text { Not being isolated contributes to building } \\
\text { a sense of power towards collective } \\
\text { action. Following the Powercube.net, } \\
\text { 'Power to' (...) when based on mutual } \\
\text { support, opens up the possibilities of } \\
\text { joint action, or 'power with'. }\end{array}$ & $\begin{array}{l}\text { Citizen met more than the median } \\
\text { number of villagers (who are not part of } \\
\text { their household) in a regular day in the } \\
\text { last } 12 \text { months. }\end{array}$ \\
\hline & $\begin{array}{l}\text { Ability to decide for } \\
\text { one's own } \\
\text { movement and } \\
\text { participation in } \\
\text { community } \\
\text { activities }\end{array}$ & $\begin{array}{l}\text { Citizens have agency to engage with } \\
\text { community activities and travel freely. } \\
\text { Following Lombardini et al. (2017), } \\
\text { "'Power to" refers to individual agency, } \\
\text { meaning the capability to decide actions } \\
\text { and carry them out'. }\end{array}$ & $\begin{array}{l}\text { Citizen decides alone whether he or she } \\
\text { can travel, or whether he or she can } \\
\text { participate in community group activities } \\
\text { and meetings. }\end{array}$ \\
\hline & Literacy & $\begin{array}{l}\text { Literacy gives the possibility to engage } \\
\text { with some activities and access written } \\
\text { information (through newspapers or } \\
\text { some online platforms in particular). }\end{array}$ & $\begin{array}{l}\text { Citizen can read and write a one page } \\
\text { document at baseline. }\end{array}$ \\
\hline & $\begin{array}{l}\text { Access to } \\
\text { information }\end{array}$ & $\begin{array}{l}\text { Citizens have regular access to } \\
\text { information through different channels } \\
\text { (radio, television, newspapers). }\end{array}$ & $\begin{array}{l}\text { Citizen accesses at least one media } \\
\text { (radio, television, newspaper) at least } \\
\text { once a week. }\end{array}$ \\
\hline & $\begin{array}{l}\text { Attitude in public } \\
\text { forum }\end{array}$ & $\begin{array}{l}\text { Perception of one's ability to stand up } \\
\text { for oneself in public forum or voice } \\
\text { opinion contributes to one's capability to } \\
\text { engage with collective actions. }\end{array}$ & $\begin{array}{l}\text { Citizen disagrees with the statement } \\
\text { 'Public forums held in your village can } \\
\text { be intimidating - it is difficult for a } \\
\text { someone like you to stand up and voice } \\
\text { any concerns' and agrees with the } \\
\text { statement 'If a decision was made in a } \\
\text { public forum which might negatively } \\
\text { affect your life and those of your } \\
\text { children, you would not hesitate to stand } \\
\text { up and protest despite the possible } \\
\text { negative consequences'. }\end{array}$ \\
\hline
\end{tabular}


The tables below show the impact of the project on each indicator for each index.

Table A4.2: Impact result on each indicator, 'power within'

\begin{tabular}{|c|c|c|c|c|c|}
\hline & $\begin{array}{l}\text { Knowledge of } \\
\text { rights and } \\
\text { responsibilities }\end{array}$ & $\begin{array}{c}\text { Belief in } \\
\text { collective } \\
\text { action's } \\
\text { effectiveness }\end{array}$ & $\begin{array}{c}\text { Self- } \\
\text { confidence }\end{array}$ & Self-esteem & $\begin{array}{c}\text { Gender role } \\
\text { about speaking } \\
\text { up }\end{array}$ \\
\hline \multicolumn{6}{|l|}{$\begin{array}{l}\text { Effect of time in the } \\
\text { comparison group }\end{array}$} \\
\hline (Time) & $\begin{array}{l}0.322^{* * *} \\
(0.0264)\end{array}$ & $\begin{array}{l}-0.0731 \\
(0.0608)\end{array}$ & $\begin{array}{c}-0.0332 \\
(0.0510)\end{array}$ & $\begin{array}{l}-0.0399 \\
(0.0315)\end{array}$ & $\begin{array}{c}0.0797^{\star} \\
(0.0417)\end{array}$ \\
\hline \multicolumn{6}{|l|}{$\begin{array}{l}\text { Effect of being in } \\
\text { the intervention } \\
\text { group at baseline }\end{array}$} \\
\hline (Project) & $\begin{array}{c}0.0249 \\
(0.0423)\end{array}$ & $\begin{array}{l}-0.0177 \\
(0.0405)\end{array}$ & $\begin{array}{l}-0.0589 \\
(0.0560)\end{array}$ & $\begin{array}{c}0.0339 \\
(0.0457)\end{array}$ & $\begin{array}{l}-0.0347 \\
(0.0496)\end{array}$ \\
\hline \multicolumn{6}{|l|}{$\begin{array}{l}\text { Impact of the } \\
\text { project }\end{array}$} \\
\hline (Time* Project) & $\begin{array}{l}-0.0480 \\
(0.0457)\end{array}$ & $\begin{array}{c}0.0781 \\
(0.0648)\end{array}$ & $\begin{array}{l}-0.00418 \\
(0.0739)\end{array}$ & $\begin{array}{c}0.0722 \\
(0.0464)\end{array}$ & $\begin{array}{l}0.00502 \\
(0.0679)\end{array}$ \\
\hline Observations & 1,404 & 1,404 & 1,404 & 1,404 & 1,404 \\
\hline $\begin{array}{l}\text { Number of citizens } \\
\text { Mean at baseline in } \\
\text { the comparison }\end{array}$ & 702 & 702 & 702 & 702 & 702 \\
\hline $\begin{array}{l}\text { group } \\
\text { Mean at baseline in } \\
\text { the intervention }\end{array}$ & 0.339 & 0.831 & 0.777 & 0.591 & 0.542 \\
\hline group & 0.404 & 0.818 & 0.696 & 0.554 & 0.464 \\
\hline
\end{tabular}

Robust standard errors in parentheses

${ }^{* * *} p<0.01,{ }^{* *} p<0.05,{ }^{*} p<0.1$

Difference-in-differences with random effects, village level clustered standard errors and control variables as described in Section 3.2.5 (Model 3) 
Table A4.3: Impact result on each indicator, 'power to'

\begin{tabular}{|c|c|c|c|c|}
\hline & $\begin{array}{c}\text { Connection } \\
\text { with other } \\
\text { citizens }\end{array}$ & $\begin{array}{l}\text { Ability to } \\
\text { decide for } \\
\text { one's own } \\
\text { movement } \\
\text { and } \\
\text { participation in } \\
\text { community } \\
\text { activities }\end{array}$ & $\begin{array}{l}\text { Access to } \\
\text { information }\end{array}$ & $\begin{array}{c}\text { Attitude } \\
\text { in public } \\
\text { forum }\end{array}$ \\
\hline $\begin{array}{l}\text { Effect of time in the comparison } \\
\text { group (Time) }\end{array}$ & $\begin{array}{l}-0.00997 \\
(0.0639)\end{array}$ & $\begin{array}{l}-0.0133 \\
(0.0242)\end{array}$ & $\begin{array}{l}-0.00997 \\
(0.0365)\end{array}$ & $\begin{array}{l}-0.00664 \\
(0.0412)\end{array}$ \\
\hline $\begin{array}{l}\text { Effect of being in the intervention } \\
\text { group at baseline (Project) }\end{array}$ & $\begin{array}{l}-0.129^{\star} \\
(0.0747)\end{array}$ & $\begin{array}{l}-0.0877 \\
(0.0541)\end{array}$ & $\begin{array}{l}0.00187 \\
(0.0435)\end{array}$ & $\begin{array}{l}-0.108^{* *} \\
(0.0479)\end{array}$ \\
\hline Impact of the project (Time ${ }^{\star}$ Project) & $\begin{array}{c}0.0201 \\
(0.0920)\end{array}$ & $\begin{array}{l}0.0882^{*} \\
(0.0501)\end{array}$ & $\begin{array}{c}0.0496 \\
(0.0532)\end{array}$ & $\begin{array}{l}0.119^{* *} \\
(0.0604)\end{array}$ \\
\hline Observations & 1,404 & 1,404 & 1,404 & 1,404 \\
\hline Number of citizens & 702 & 702 & 702 & 702 \\
\hline $\begin{array}{l}\text { group } \\
\text { Mean at baseline in the intervention }\end{array}$ & 0.515 & 0.492 & 0.585 & 0.332 \\
\hline group & 0.514 & 0.426 & 0.636 & 0.257 \\
\hline
\end{tabular}

Robust standard errors in

parentheses

${ }^{* * *} p<0.01,{ }^{* *} p<0.05,{ }^{*} p<0.1$

Difference-in-differences with random effects, village level clustered standard errors and control variables as described in Section 3.2.5 (Model 3) 


\section{REFERENCES}

Caliendo, M. and Kopeinig, S. (2008). Some Practical Guidance for the Implementation of Propensity Score Matching. Journal of Economic Surveys, 22(1), 31-72.

Filmer, D. and Pritchett, L. H. (2001). Estimating Wealth Effects without Expenditure Data - Or Tears: An Application to Educational Enrollments in States of India. Demography, 38(1), 115-32.

Fuller, R. and Pretari, A. (2018). Resilience in Burkina Faso: Impact Evaluation of the 'Resilience, Food Security and Nutrition' project. Effectiveness review 2016/17, Oxfam GB.

Gismondi, M. and Pretari, A., (2018). Governance and Accountability through Digitalization, Baseline report. Oxfam

Green, D., (2015) The Chukua Hatua Accountability Programme, Tanzania, Oxfam Active Citizenship Case Study

Heckman, J. J., LaLonde, R. J. and Smith, J. A. (1999). The Economics and Econometrics of Active Labor Market Programs, Handbook of Labor Economics, 3(A), 1865-2097.

Hirano, K. and Imbens, G. W. (2001). Estimation of Causal Effects using Propensity Score Weighting: An Application to Data on Right Heart Catheterization. Health Services \& Outcomes Research Methodology, 2(3), 259-78.

Hopkins, A., Bradie, C. and Brownlie, A. (2014), The Right to be Heard Framework, a Learning Companion, Oxfam https://policy-practice.oxfam.org.uk/publications/the-right-to-be-heard-framework-a-learning-companion$\underline{254793}$

Human Rights Watch, East Africa: civic space shrinking, 17 January 2019: https://www.hrw.org/news/2019/01/17/east-africa-civic-space-shrinking

Human Rights Watch (2019). World Report 2019, events of 2018

Lombardini, S., Bowman, K. and Garwood, R., (2017) A 'How To' Guide to Measuring Women's Empowerment Sharing experience from Oxfam's impact evaluations, Oxfam GB https://policypractice.oxfam.org.uk/publications/a-how-to-guide-to-measuring-womens-empowerment-sharingexperience-from-oxfams-i-620271

Lombardini, S. and Mager, F. (2019). Impact Evaluation of Oxfam's Cash For Work activities in the Za'atari camp (Jordan). Effectiveness review 2018/19, Oxfam GB.

Ministry of Health, Community Development, Gender, Elderly and Children (MoHCDGEC) [Tanzania Mainland], Ministry of Health (MoH) [Zanzibar], National Bureau of Statistics (NBS), Office of the Chief Government Statistician (OCGS), and ICF. 2016. Tanzania Demographic and Health Survey and Malaria Indicator Survey (TDHS-MIS) 2015-16. Dar es Salaam, Tanzania, and Rockville, Maryland, USA: MoHCDGEC, MoH, NBS, OCGS, and ICF.

Powercube.net, Participation, Power and Social Change team at the Institute of Development Studies, University of Sussex. https://www.powercube.net/

ResearchICTAfrica.net, Cost of smartphones continues the digital divide in Tanzania, Policy Brief 4.August 2017: Tanzania

Rosenbaum, P. R. and D. B. Rubin. (1983). The Central Role of the Propensity Score in Observational Studies for Causal Effects. Biometrika, 70(1), 41-55.

Rowlands, J. (1997). Questioning Empowerment: Working with Women in Honduras. Oxfam https://policypractice.oxfam.org.uk/publications/questioning-empowerment-working-with-women-in-honduras-121185

Smith, R. D. and Kishekya, D. (RDS Consulting LTD) (2013). Chukua Hatua, Tanzania, Effectiveness review, Oxfam GB.

VeneKlasen, L. and Miller V. (2002), A New Weave of Power, People \& Politics, World Neighbors. 
${ }^{1}$ Human rights Watch, East Africa: civic space shrinking, 17 January 2019: https://www.hrw.org/news/2019/01/17/east-africa-civic-space-shrinking

2 Duncan Green, The Chukua Hatua Accountability Programme, Tanzania, Oxfam Active Citizenship Case Study, 2015; Richard D. Smith and Dunstan Kishekya, RDS Consulting LTD, Chukua Hatua, Tanzania, Effectiveness review, Oxfam, 2013.

${ }^{3}$ See https://en.wikipedia.org/wiki/Cybercrimes Act in Tanzania

${ }^{4}$ Human rights Watch, East Africa: civic space shrinking, 17 January 2019: https://www.hrw.org/news/2019/01/17/east-africa-civic-space-shrinking

${ }^{5}$ http://www.powercube.net, a project from the Participation, Power and Social Change team at the Institute of Development Studies, University of Sussex.

${ }^{6}$ This criterion was harder to meet than anticipated: in the first selection of animators made by partners in Arusha, Geita and Mtwara, a lot of animators were involved in politics. Hence second selection was made to meet this criterion (which made the final list of animators).

${ }^{7}$ Due to a relatively small pool of villages from which to draw a comparison group, and due to resource constraints, it was decided to keep the scope of the survey relatively focused.

${ }^{8}$ Chukua Hatua was implemented from 2010 to 2015, with an extension of its scope in 2015, by which animators recruited and trained new animators to ensure sustainability after the end of direct support. In Arusha, comparison villages are located in the same district as the project, while in Geita they are located in a different district. The governance project in Lindi rural, whose villages serve at comparison group, took place in 2017 and 2018. This project focuses on extractive industry, which is a key issue in both Lindi rural and Mtwara rural. Lindi and Mtwara rural areas are part of the same ecosystem, facing similar environmental, economic and social issues.

${ }^{9}$ In Kigoma, the project is new and no governance project was ongoing in a similar rural setting as this project. Three pure control villages were identified at baseline. They will not be included in the analysis in this report because of the focus on identifying the added-value of the digital component.

10 Note that in the comparison group, surveying the sampled animators was challenging due to animators having migrated or not being active anymore, requiring re-sampling, particularly in Geita region where the current project partner did not know the former Chukua Hatua animators.

11 In case these lists were not available, lists of hamlets were used. Finally, if no list was available, the survey team used the random walk technique to identify respondents.

12 https://cognitive-edge.com/sensemaker/; see Fuller and Pretari (2018) and Lombardini and Mager (2019) for examples of using SenseMaker in quasi-experimental impact evaluations.

13 See Module S: https://researchictafrica.net/publications/Other_publications/2017_RIA_HH_and_IND_Questionnaire.pd f

${ }^{14}$ Most of it is due to migration outside of the village and the survey area (32 percent of the respondents who could not be surveyed) and unavailability for a long period of time - longer than the survey duration (39 percent).

15 Note that this is a small sample by statistical standards.

16 Unfortunately, the survey did not ask for how long they had been an animator.

${ }^{17}$ We use principal component analysis using asset ownership at baseline to compute a measure of wealth among the surveyed sample, following the approach of Filmer and Pritchett (2001).

18 Given the panel structure of our dataset, we use a random effect model. This allows us to estimate effects of time-invariant variables (control variables) but requires making the assumption that all timeinvariant unobservable variables are captured by the model. We also estimated the model with fixed effects on a few outcome indicators, and the results are not changed.

${ }^{19}$ See the full case study report for more details on the methodology.

20 As mentioned in Section 3.2.5, the animator sample size is small by statistical standard.

${ }^{21}$ We used a Linear Probability Model to model the dummy variable 'know any person playing the role of animator' measured at endline, clustering at village level. The model looks at the association of a given characteristics, controlling for all the other characteristics in the model. The model includes all of the matching variables used in Model 4, as well as the animator characteristics included in Model 3, the intervention variable, and whether the citizen knew any person in the role of animator at baseline. We ran the model for the whole sample of citizens, and then for women and men separately.

22 Respondents could choose several options, hence the fact that this does not add up to 100 percent.

${ }^{23}$ We used a Linear Probability Model to model the dummy variable 'Uses social media' measured at endline, clustering at village level. The model looks at the association of a given characteristics, controlling for all the other characteristics in the model. The model includes all of the matching 
variables used in Model 4, as well as the animator characteristics included in Model 3, and the intervention variable. We ran the model for the whole sample of citizens, and then for women and men separately.

${ }^{24}$ As mentioned in the Right to be heard framework: a learning companion.

${ }^{25}$ We did not detect them being invited a significantly different number of times among those who were invited.

${ }^{26} \mathrm{https}: / /$ cognitive-edge.com/sensemaker/; see Fuller and Pretari (2018) and Lombardini and Mager (2019) for examples of using SenseMaker in quasi-experimental impact evaluations.

27 This is among the stories in which social media is involved, the sample size being hence very small ( 26 observations).

28 The stories have been edited to ensure confidentiality.

29 The three stories presented below were chosen because they are in different regions and are explicit either on the use of social media or on which leaders or officials were involved (among 23 stories).

30 This does not seem associated with gender or age of the respondent; respondents from Geita seem less likely to know the law on this topic, compared to the other regions in the intervention group.

31 The sample size is reduced due to missing data in the baseline survey in the asset module and meeting group module.

${ }^{32}$ Bootstrapping is a statistical procedure where repeated samples are drawn from the original sample and parameters, such as standard errors, are re-estimated for each draw. The bootstrapped parameter is calculated as the average estimate over the total number of repeated draws.

${ }^{33}$ See Oxfam Policy and Practice website for more on the Effectiveness Review: https://policypractice.oxfam.org.uk/our-approach/monitoring-evaluation/effectiveness-reviews

34 See OPHI's website for more on the Alkire-Foster method to measuring multidimensional poverty https://ophi.org.uk/research/multidimensional-poverty/alkire-foster-method/ 


\section{Oxfam Effectiveness Reviews}

For more information, or to comment on this report, email policyandpractice@oxfam.org.uk

(C) Oxfam GB August 2019

This publication is copyright, but the text may be used free of charge for the purposes of advocacy, campaigning, education, and research, provided that the source is acknowledged in full. The copyright holder requests that all such use be registered with them for impact assessment purposes. For copying in any other circumstances, or for re-use in other publications, or for translation or adaptation, permission must be secured and a fee may be charged. Email policyandpractice@oxfam.org.uk.

The information in this publication is correct at the time of going to press.

ISBN: 978-1-78748-476-4

DOI: $10.21201 / 2019.4764$

Oxfam GB, Oxfam House, John Smith Drive, Cowley, Oxford, OX4 2JY, UK.

\section{OXFAM}

Oxfam is an international confederation of 19 organizations networked together in more than 90 countries, as part of a global movement for change, to build a future free from the injustice of poverty. Please write to any of the agencies for further information, or visit www.oxfam.org.

Oxfam America (www.oxfamamerica.org)

Oxfam Australia (www.oxfam.org.au)

Oxfam-in-Belgium (www.oxfamsol.be)

Oxfam Brasil (www.oxfam.org.br)

Oxfam Canada (www.oxfam.ca)

Oxfam France (www.oxfamfrance.org)

Oxfam Germany (www.oxfam.de)

Oxfam GB (www.oxfam.org.uk)

Oxfam Hong Kong (www.oxfam.org.hk)

Oxfam IBIS (Denmark) (http://oxfamibis.dk/)

Oxfam India (www.oxfamindia.org)

Oxfam Intermón (Spain) (www.oxfamintermon.org)

Oxfam Ireland (www.oxfamireland.org)

Oxfam Italy (www.oxfamitalia.org)

Oxfam Mexico (www.oxfammexico.org)

Oxfam New Zealand (www.oxfam.org.nz)

Oxfam Novib (Netherlands) (www.oxfamnovib.nl)

Oxfam Québec (www.oxfam.qc.ca)

Oxfam South Africa (http://www.oxfam.org.za/)

Observers

KEDV (Oxfam Turkey) 